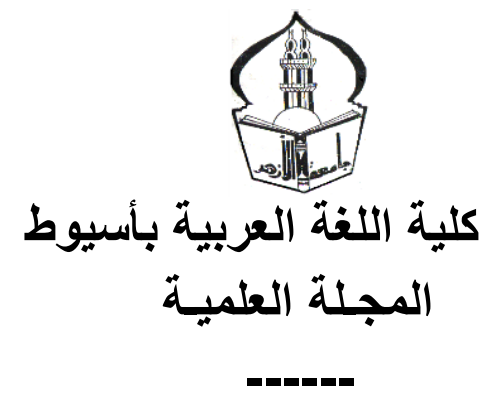

حروف المعاني ودلالتها في الكلام بين

الثزاث النحوي والدراسات النحوية الهديثة

إعداد

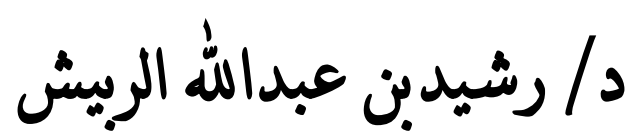

أستاذ النحو والصرف المساعد

في كلية اللغة العربية بجامعة القصيم

( العدد الخامس والثُاثون الجزء الأول 19 • ب م ) 
Research title: The Preposition: Its Rank and Significance in Speech between Grammar Heritage and Modern Grammar Studies: A Comparative and Descriptive Study. By Dr Rashid Al-Rubeesh, Assistant Professor of Grammar and Morphology, College of Arabic Language, Qassm University 


\section{ملفص البمث}

قصدت بـالحرف هنـا مـا اصطلح النحويـون على تسـميته بحروف المعـاني، ولاثك أن لحروف المعاني أثرًا كبيرًا ليس في بناء الجملة العربية وتركيبها فحسب، بل في دلالتها السياقية، وتناسقها وإنسجامها، وهو ما عرف بلاغيًا بنظريـة النظم،

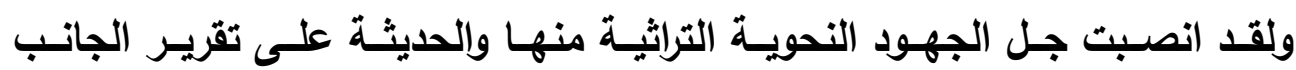
الصناعي فيها، وإيضـاح معانيها مفردة، غير أنسي سأرصد في هذه الاراسـة آراء النحويين القدماء والمحدثين في رتبة الحرف ومنزلته بين أجزاء الكلام، كما سأتناول أيضًا البعد الالالي للحرف من خلال روئة قدماء النحويين واختلافهم في ذلك، ونظر الارس النحوي الحديث.

هنهج البمث : سأعتمد في بحثي ـ ابتداء ـ على المنهج الوصفي القائم على اسـتخلاص أبرز آراء النحويين القدماء في كتبهم، أو مـا نقل عنهم حول رتبـة الحرف ودلالته في ذاته واستظهارها. وبسأقوم بعد ذلك بمقارنـة آراء القدماء بمـا لدى المعاصرين من رؤى جديدة، ثم إخضاع تلك الآراء قديمها وحديثها لمنهج النقد والتحليل. خطة البمـث : لقد رأيث تقسيم هذا البحث إلى مقدمـة، وتمهيد، ومبحثين، وخاتمة، وذيلته بفهارس للمصادر والموضوعات. التمهيد: ذكرت فيه مصطلح الحرف، وسبب تسميته، وخلاف النحويين في

البهم الأول: رتبة الحرف بين قسيميه (الاسم، والفعل) وفيه مطلبان : الامطلب الأول : رتبته عند قدامى النحويين. الامطب الثاني : رتبته عند المحدثين. 
المبـث الثاني: البعد الدلالي للحرف، وفيه مطلبان : المطاب الأول : دلالته عند القدماء. الاملب الثاني : دلالته عند المحدثين.

ثم الخاتهة، فالمسادر والمراجع . 


\section{Abstract}

In this study, the preposition is meant, according to grammarians, prepositions of meaning. Undoubtedly, not only prepositions of meaning have great effect on the structure and construction of the Arabic sentence, but also on its contextual semantics, conformity and uniformity. Rhetorically, this is known as Al-nizm theory. All ancient and modern grammar efforts were exerted on confirming the drafting side of it and clarifying its meaning. However, the researcher will cite the ancient and modern grammarians' opinions about the preposition rank and position among speech parts. Additionally, the semantic dimension of the preposition will be examined in terms of the ancient grammarians' vision and their difference about this and the view point of the current grammar research. Methodology: the research adopts the descriptive method based on citing the most important opinions of ancient grammarians in their books, or what was quoted from them about the preposition rank and significance. Then, the researcher will compare the ancient and modern grammarians' opinions; after that, the old and new opinions will be subjected to the method of criticism and analysis. Research plan: this research is divided into an introduction, 
a preface, two sections and a conclusion, followed by references and topics. The preface tackles the term preposition, the reason for this name, and the difference among grammarians about that. The first section deals with the preposition rank between its parts (noun and verb). This section is divided into two subsections: $(A)$ the rand according to old grammarians; the rand according to modern grammarians. (B) The semantics of the preposition according to modern grammarians. Finally a conclusion is reached, followed by references. 


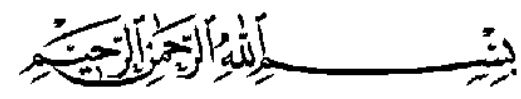

\section{مقدمة}

الحمد الله وحده، والصلاة والسلام على من لا نبي بعده، ويعد: فلما كان لحروف المعاني أثز كبيز، ليس في بنـاء الجملة العربية ودلالتها فحسب، بل في تناسقها وإنسجامها وحسن سبكها، كانت فكرة هذا البحث، ليتـاول جانبا مهما من جوانب الدرس النحوي المقارن ألا وهو(حروف المعاني ودلالتها في الخطاب بين التراث النحوي والدراسات النحوية الحديثة)

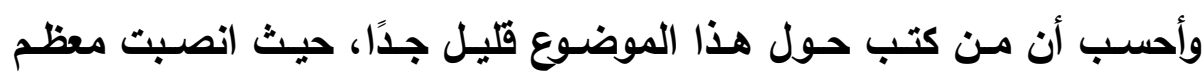

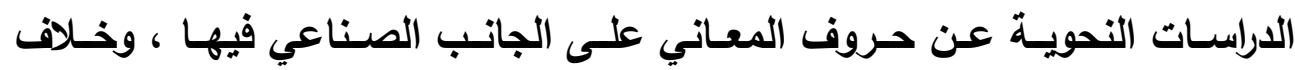
التحويين في بساطتها وتركيبها وإعمالها وإهمالها ونحو ذلك . ولم أقف على من خص بدراسة مستقلة موضع الحرف من الكلم ودلالته في

الخطاب بين النحويين القدماء والمعاصرين دراسة مقارنة .

و لقد رأيت تقسيم هذه الدراسة إلى مقدمة، وتمهيد، ومبحثين، وخاتمة. ذكرت في التمهيد مصطلح الحرف، و سبب تسميته، وخلاف النحويين في

تحديده.

وكان المبمسث الأول للحديث عن : ( موضع حروف المعاني من الكلم عند القدماء والمحدثين ) - أن أمـا المبــث الثـاني فتناولت فيـه : ( دلالـة حروف المعـاني عند القدماء والمحدثين )

و ذيلت هذا البحث بخاتمة، أعقبتها بفهرس للموضوعات وآخر للمراجع . 
والله أسـأل أن تكون هذه الدراسـة إضـافة نافعة في حقل الاراسـات النحويـة

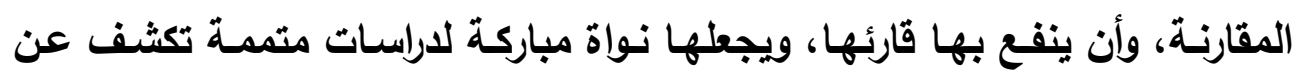
أسرار الحروف والأدوات ووظائفها الدالية في الخطاب. 


\section{Ant}

من المعروف أن قامى النحاة قد صنفوا الكلم إلى اسم وفعل وحرف، وصنفوا

$$
\text { الحرف إلى حرف مبنى وحرف معنى • }
$$

أما حرف المبنى، فهو الأي يمثل أحد أجزاء الكلمـة، وهو لا يلال على معنى في نفسـ، ولا في غيره (مفردًا كان أو مركبًا ) وذلك مثل حرف الضـاد (ض) في كلمة (ضرب) فحرف الضاد لا يدل على معنى في نفسه ولا في غيره، ولكنه دخل في بناء وتركيب كلمة (ضرب) فصار لها معنى لأنه أحد أجزاء الكلمة . أما حرف المعنى فيدل على معنى يتجلى من خـلال التركيب والسياق الوارد

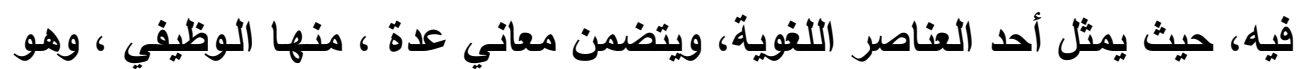
مـا تؤديـه الكلمـة بمـا لها من معنى حقيقي أو مجازي في سياق تركيب مـا، حيث

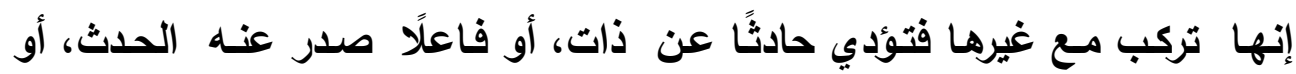

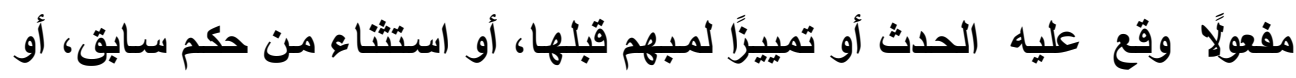
شرطًا لحكم لاحق، أو ربطًا بين مكونات الجملة وتكوين نظام متآلف يبدع معاني

نحوية، تكثف مقاصد أسلويية و بلاغية ( ')

وجدير بالذكر أن النحويين اختلفوا في استعمال مصطلح (الكلم) و(الكـلام)

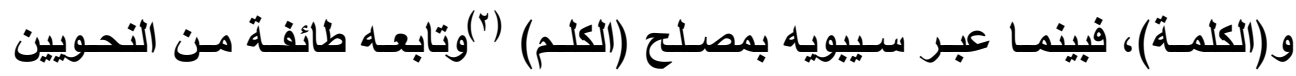

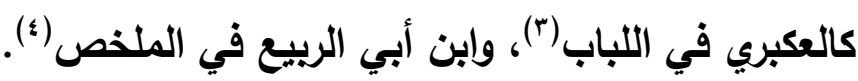

(1) ينظر بحث"معنى الحروف بين النحاة والأصوليين" د.مجاهد منصور مصلح صبّا، منشور في

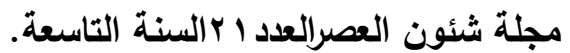

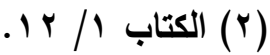

$$
\begin{aligned}
& \text { ، }\{r / 1(r) \\
& \text { ( ) ص ا } 1.1
\end{aligned}
$$


عبر آخرون بمصطلح (الكلمة) كالزمخشري في المفصل (')، وابن مالك في شرح التسهيل(؟).

وأبي حيان في التذييل وإلتكميل(")، والسيوطي في الهمع (؛).

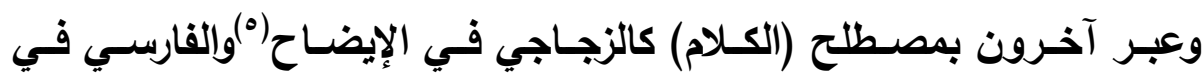

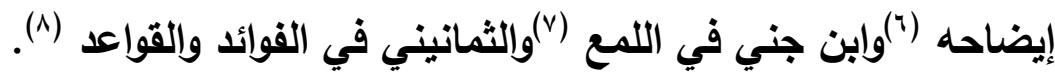

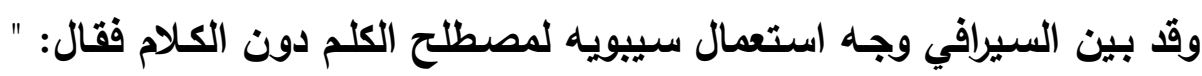

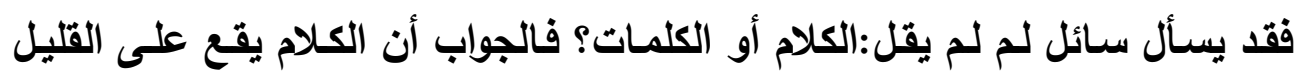

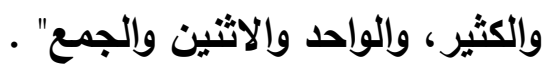

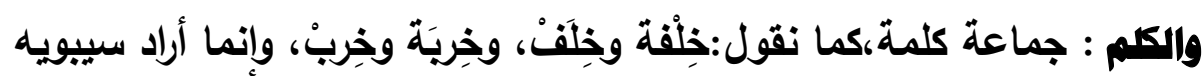
أن يبين الاسم والفعل والحرف وهى جمع فأراد أن يعبر عنها بأشكل الألفاظ وأثبهها وخها بحقيقتها . ووجسه ثـان: " أن الكلم اسم ذات الثــءء، وإلكـلام اسم الفعل المصرف من .

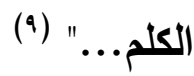
ثم أردف ذلك بقولهه : "ولو ذكر الكلام مـا كان معيبًا، ولكنهـ اختار الأفصح

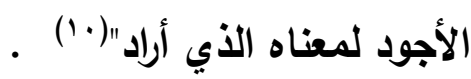

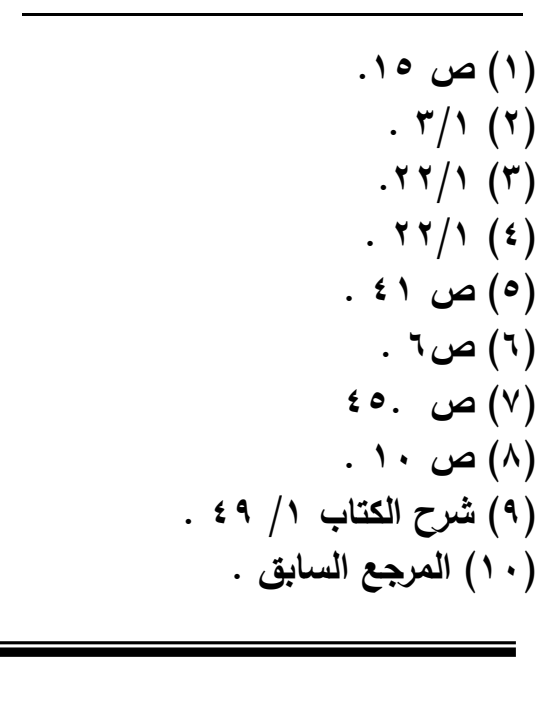


في حين عد السهيلي التعبير بالكلام معيبًا واعترض الزجاجي منتقدًا عبارته بقوله : "...وهى عبارة على طولها مردودة...ووجه الرد على أبى القاسم في عبارتهـ لئه

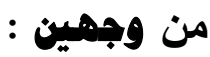
الأول: أنه عبر بالكلام عن الكلم، الأي هو جمع كلمة...وأما الكلام فهو اسم مفرد، يعبر عن المعنى القائم في النفس التي تدل عليه العبارات، وما يصطلح عليه من الإشارات، ثم قد يسمى اللفظ الدال عليه كلامًا على مذهب العرب، لفئ في تسميتهم

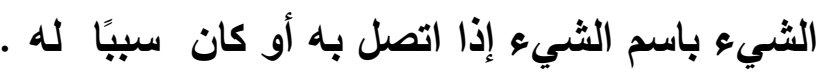

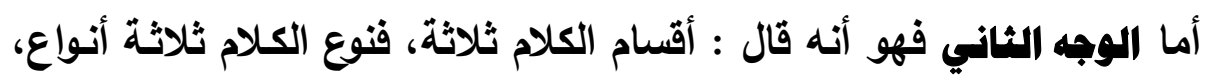

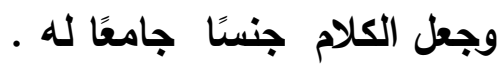

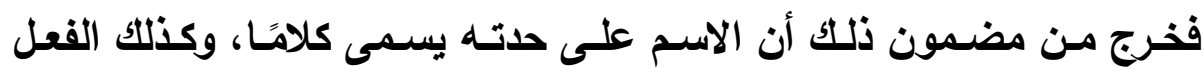

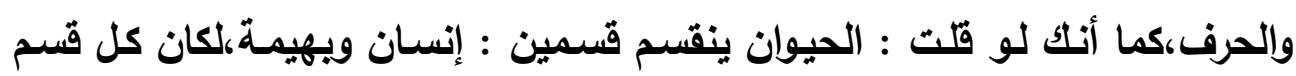

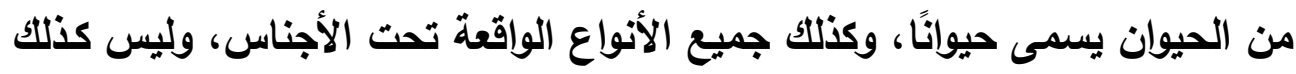

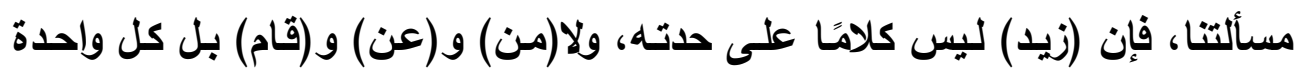

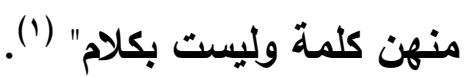

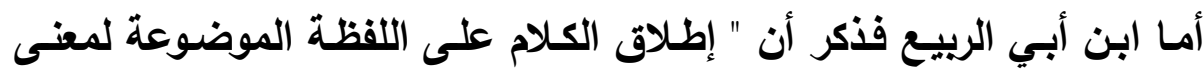

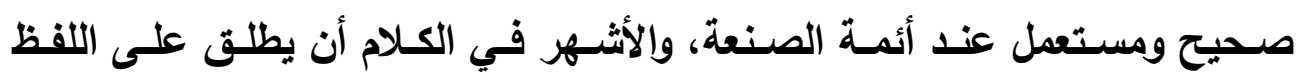

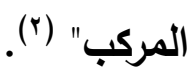
وأما الحيدرة فجعل الكلم والكلام بمعنى فقال : "واعلم أن كل كلام كلم، وكل

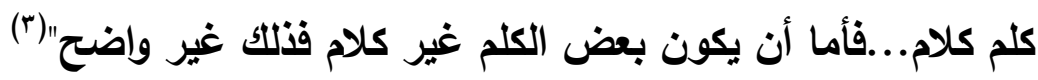
(1) نتائج الفكر ص ال،، الإفصاح ببعض ما جاء من الخطأ في الإيضاح لابن الطراوة المالقي

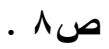

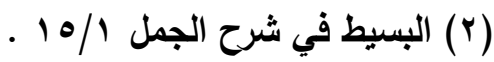

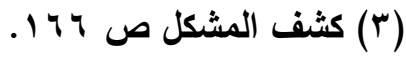


أما ابن الأنباري ففرق بين المصطلحين بقولـه : "فإن قيل : فما الفرق بين

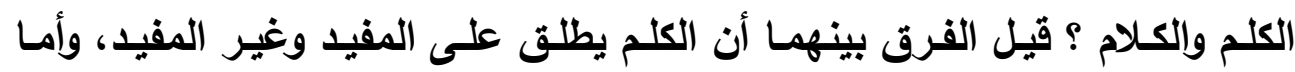

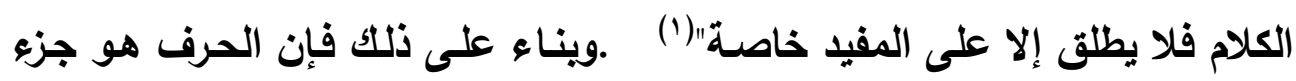
مما تتم به الفائدة من الكلام المؤثر في اللهامع.

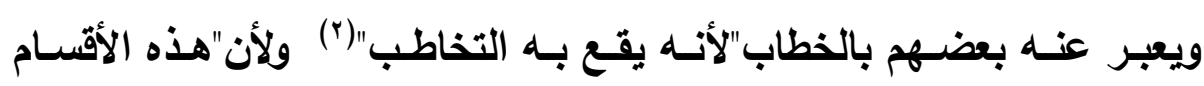

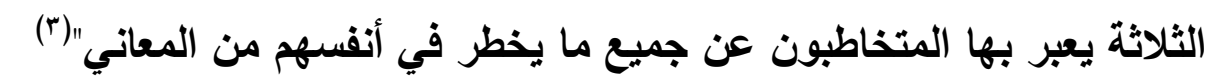

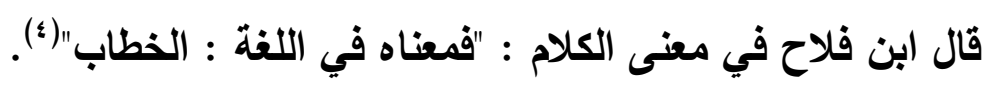
وقد ورد في اللسان أن الخطاب والمخاطبة: مراجعة الكلام، وقد خاطبه بالكلام

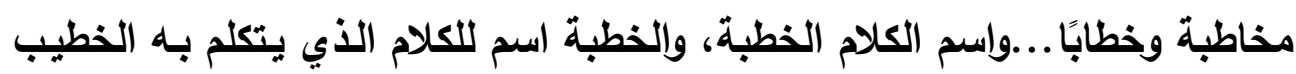

ومصطلح الخطاب هو مـا تقدمه الدراسـات اللسانية الحديثة مرادفًا لمصطلح

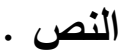

\section{هصباه المرف وهرادفاته:}

لقد اختلف النحاة في سبب تسمية حرف المعنى حرفًا، رغم كونـه قد

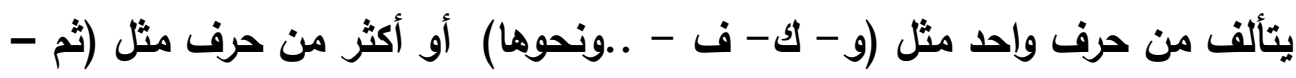

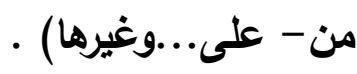

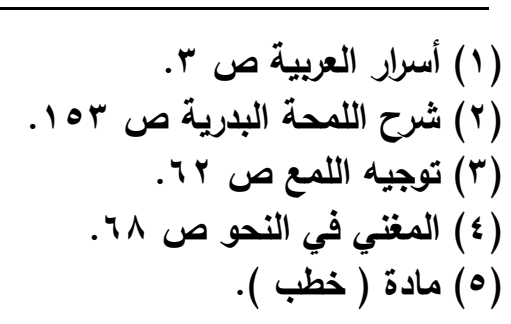




\section{وذكروا لذبك وجوها :}

فذكر الزجـاجي أنـه إنمـا " سـمى القسم الثالث حرفًا لأنـه حد مـا بين هذين القسمين ورياط لهما، والحرف حد الثيء، فكأنه لوصله بين هذين،كالحروف التي

تلي ما هو متصل بها" (1) أما الحيدرة فقد ذهب إلى أنه إنما " سمي حرفًا لضعفه، وضعف من حيث كان

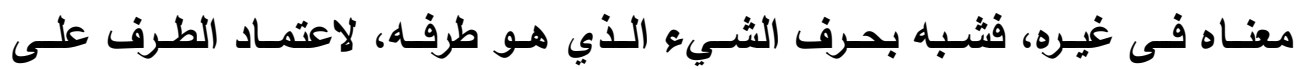
غيره،ولأن الحرف نزل منزلة الجزء من الكلمـة...، وإن أخذته من حيث ضعف ولـم يأتلف منه كلام تام، فهو مشبه بالناقة الضعيفة التي ضعفت عن الحمل والامتهان،

واسم تثلك الناقة حرف"(r) وفي اللباب " وسمي القسم الثالث حرفًا لأن حرف كل شيء طرفه، والأدوات

بهذه المنزلة؛ لأن معانيها في غيرها، فهي طرف لما معناها فيه " (َ). وزاد ابن فـلاح اليمني في المغني وجهيـن آخريسن فقـال : "إنـه سـمي حرفًا لانحرافه عن علامات الأسماء والأفعال، وقيل سمي حرفًا لكثرة معانيه، من قولهم : رجل محترف إذا كان متقنًا في الصنائع"(£) أما ابن هشام فقد زعم أن سبب تسميـة

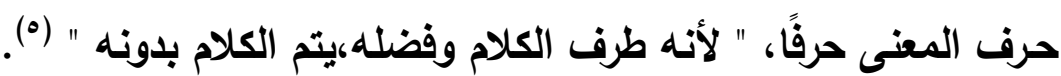

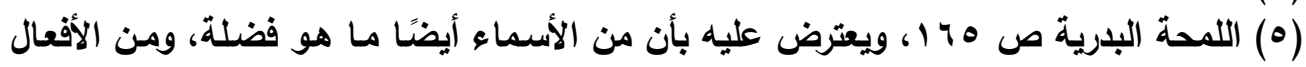
ما يتم الكلام بدونه أيضا. 
أما مرادفات الحرف، فقد استخلم بعض النحويين مصطلح(الأداة) عوضًًا عنه

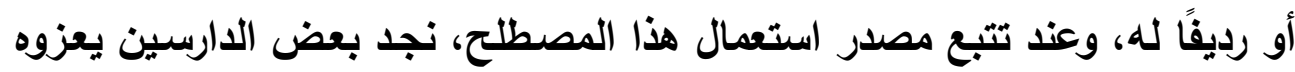

للكوفيين والفراء مقابل ما يسميه البصريون حروف المعاني (').

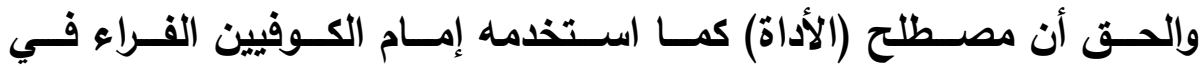

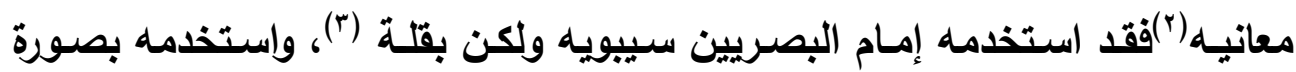

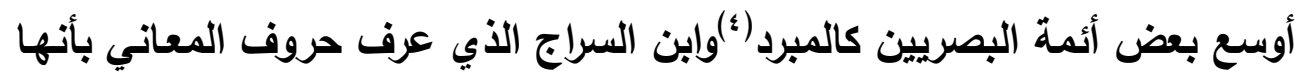
" أدوات قليلة تدخل في الأسماء والأفعال" (॰). وقد ظهر لـي أن استخدام بعض أئمسة البصريين وإلكوفيين لمصطلح ( الأداة

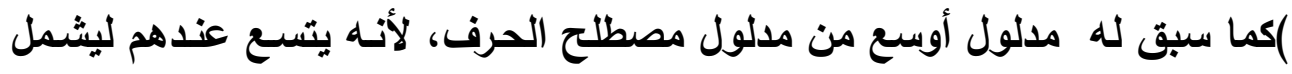

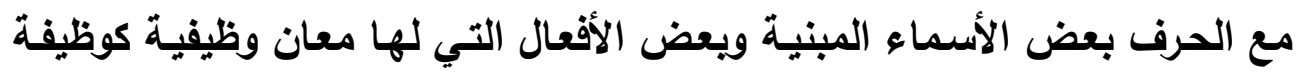
الحرف، مثل أدوات الثرط والاستفهام والنواستخ.

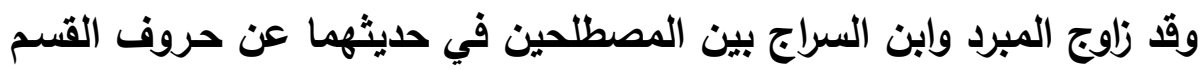
وأدوات الاستفهام والجزاء فاستعملا أحدهما رديفًا للآخر .

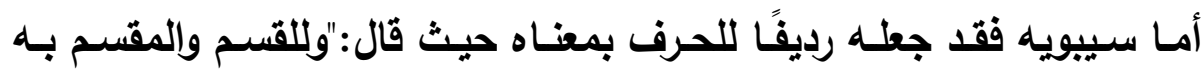

$$
\text { أدوات في حروف الجر(") وعد منها (الواو) و(التاء) و (الباء) . }
$$

(1) المصطلح النحوي لعلي القوزي ص V V الومصطلحات النحو الكوفي د.عبد الله الخثران ص $.11 \mathrm{~V}$

$$
.1 r \cdot / r-0 \Lambda_{6} \Delta r / 1(r)
$$

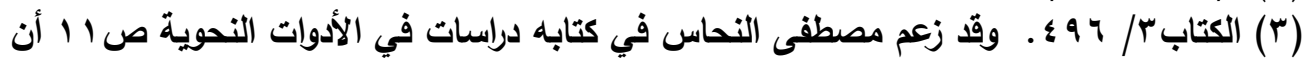

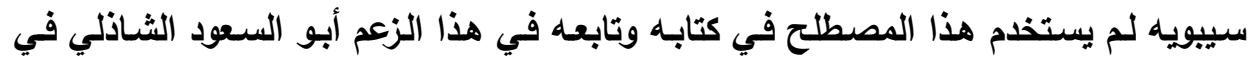

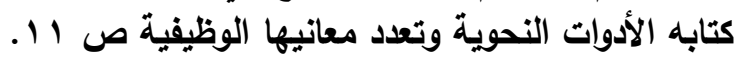

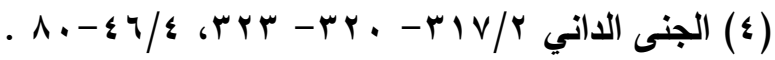

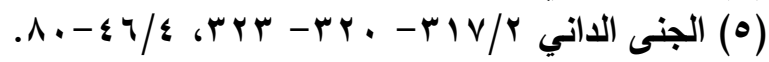

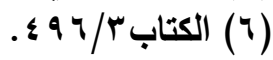


وقد قصر بعضهم مصطلح الأداة على ما سمى حروف المعاني كخلف الأحمر

في مقدمته حيث قال : "الكلمة : اسم وفعل وحرف وهو(الأداة)" (1).

وكذا فعل أبو عبد الله الطوال والفارابي فيما نقله عنهما ابن السيد (؟). كمـا فسـر ابـن الخشـاب مصسطلح الأدوات بـالحروف فقـال:"الأدوات هـي

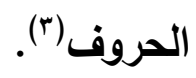

أمـا متـأخرو النحويين كـابن مالك ، والمـرادي ، وابـن هشـام ، والأثــوني ، والسيوطي، وغيرهم، فتلب عليهم استعمال مصطلح الأدوات على حروف المعاني

وما شاكلها من الأسماء والأفعال والظروف وعي، (؛). ومما يشار إليه أن ابن هشـام سمس حروف المعانسي أيضـًا بالمفردات وهـى

تعنى عنده الحروف وما تضمن معناها من الأسماء والأفعال والظروف(॰). أمسا المحثثون فقد تبلور موققهم من مصطلح الأداة على نحو لا يختلف كثيرًا عن آراء النحويين القدماء،فمنهم من عبر بالأدوات والحروف معًا،وجعل مصطلح ماتح

الأدوات لحروف المعاني وما شابهها من الأسماء والأفعال والظروف (ج). ومنهم - وهم بعض المجددين - من استعاض في تقسيمه الكلم عن مصطلح الحرف بالأداة بمعناها الشامل كابراهيم أنيس، ومهدي المخزومس، ومحمد حماسـة عبد اللطيف، وتمام حسان (1).

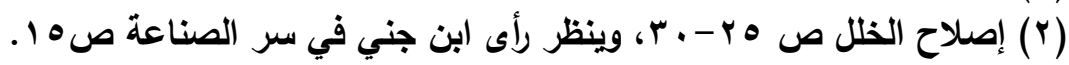

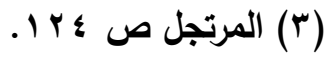

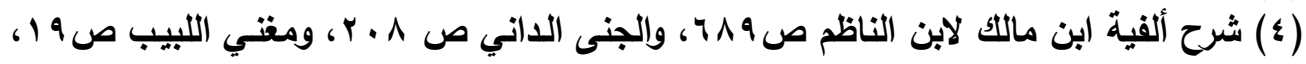

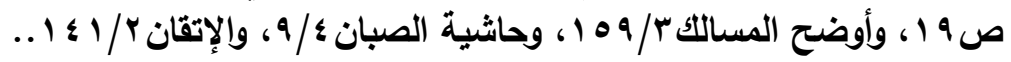

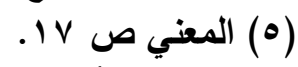

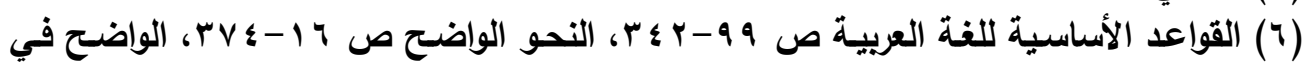

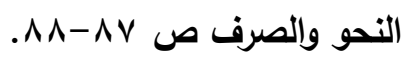




\section{اختلاف النماة في تمديد المرف :}

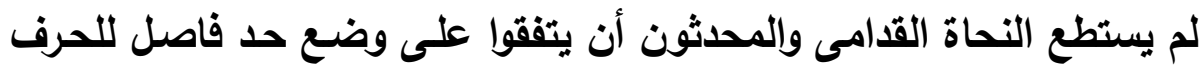

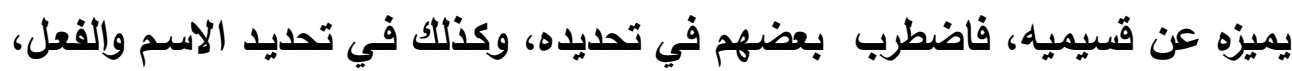
وتداخلت الحدود كثيرًا، ففي حين عد جمهورهم الكلمات التي تستخدم في الاستفهام

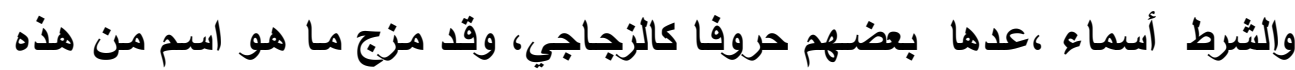

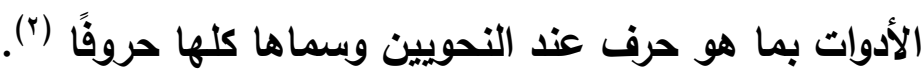

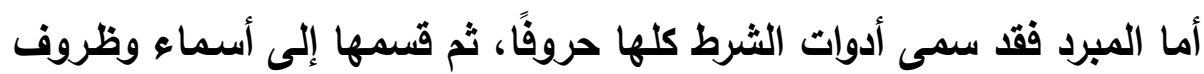
وحروف، وعبر أحيانًا بمصطلح الحرف عما هو اسم منها، مثل(مهمـا ) و(متى) أهماء

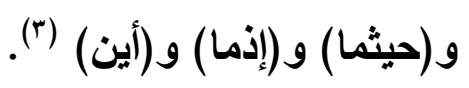

ثم عاد ونص على أن (إن) ليست باسم ولا فعل وإنما هي حرف (\$)كما عد

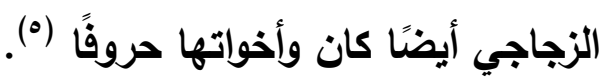

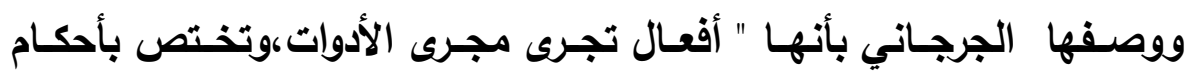

مختلفة"("). (2)

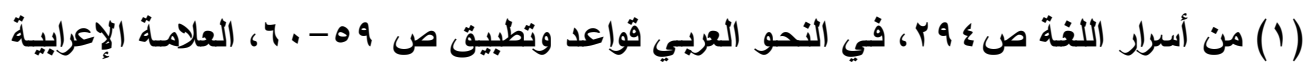

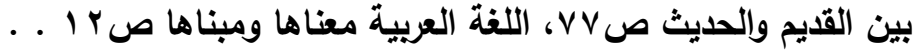

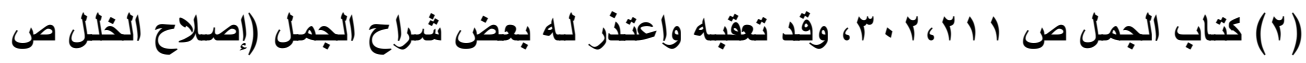

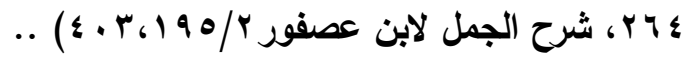

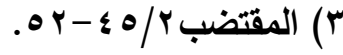

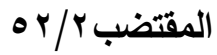

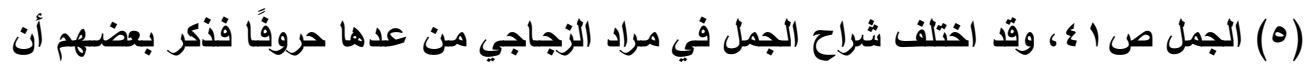

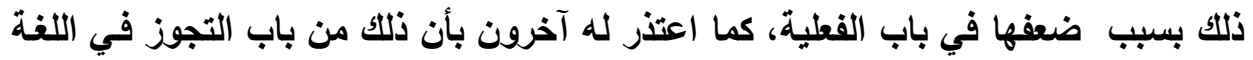

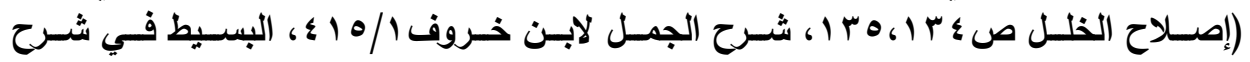

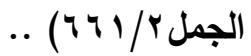

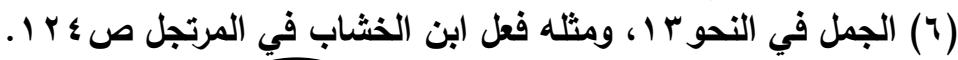


أمسا ابن يعيش فقد نقل عن بعضهم أنها " أفعال عبارة " ثم بين ذلك ألك

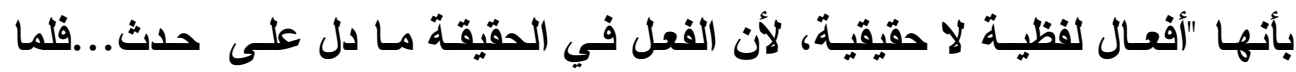

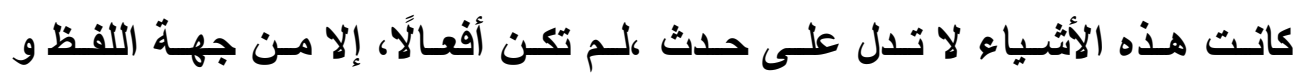
(التصرف" (1)

وذهب السيوطي إلى أنها ليست بأفعال صحيحة، وحقها ألا تعمل شيئًا، إذ

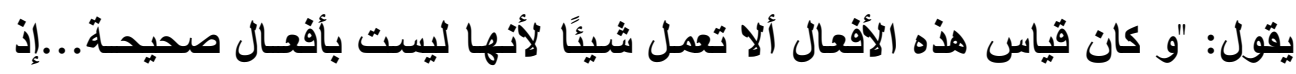

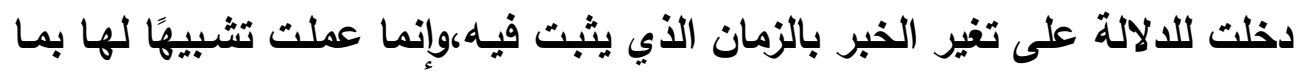

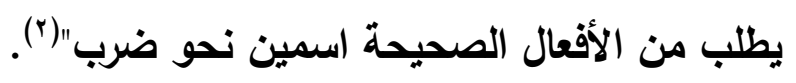
ومن المحثثين الدكتور تمام حسان الذي عدها أدوات محولة من الفعلية (").

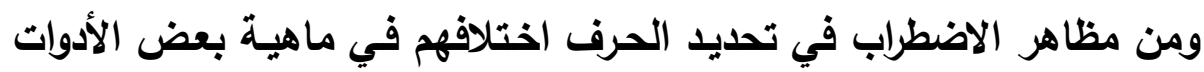

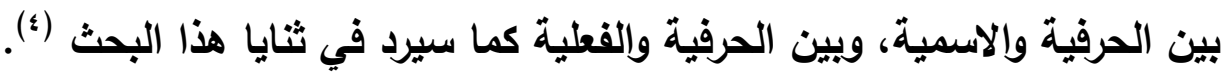

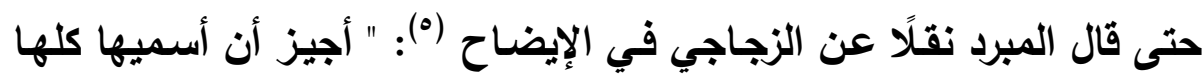

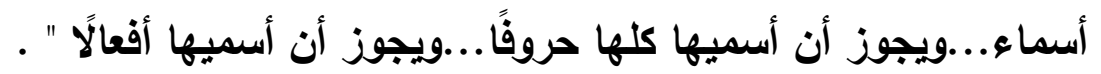
وقد شدد الدكتور إبراهيم أنيس النكير على النحويين في اضطرابهم هذا فقال أنال

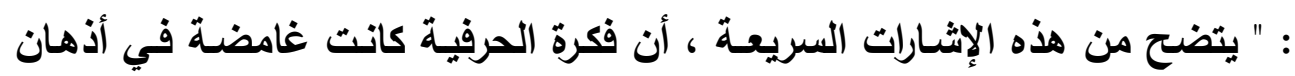

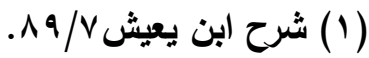

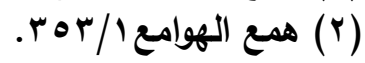

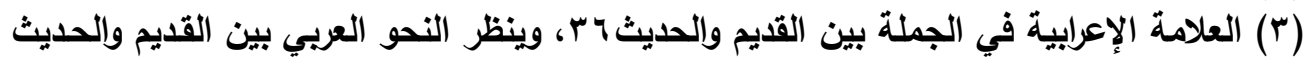

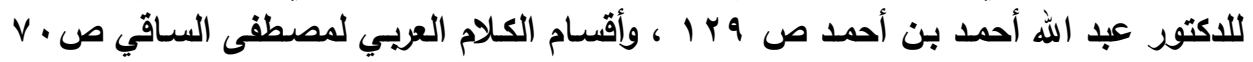

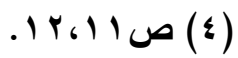

$$
\begin{aligned}
& \text { (0) }
\end{aligned}
$$


النحاة، وأن تعاريفهم للأسماء والأفعال ليست جامعة مانعة، ولعلهم أحسوا بشيء

من هذا حين لجأوا إلى ما سموه علامات الأسماء...وعلامات الأفعال"(1) . . 


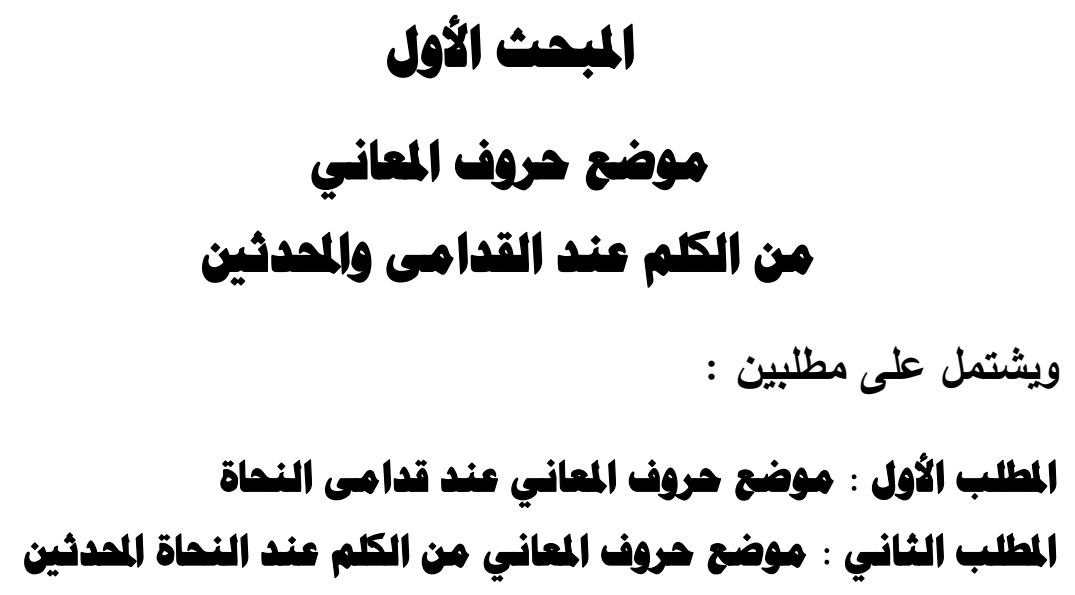




\section{المطاب الأول}

\section{موضع حروف المعاني عند قداهى النهاة}

قسم النحويون القدماء الكلم (الكلام) إلى ثُلاثة أقسام (اسم وفعل وحرف) .

يقول سيبويه :"الكلم اسم وفعل وحرف جاء لمعنى "( ") .

ويقول المبرد :"الكلام كله اسم وفعل وحرف جاء لمعنى. لا يخلو الكلام عريبًا

كان أو أعجميًا من هذه الثلاثة"(ب) . وهو مـا عبر بـه أبو القاسـم الزجـاجي قائلًا :"أقسـام الكـلام ثلاثة، اسـم وفعل

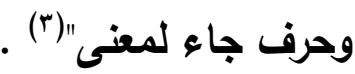
أمسا الزمخشري فيصف الكلمسة بأنها :"جنس تحته ثلاثنة أنواع الاسم والفعل

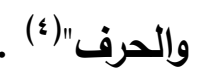

\section{تماليل التقشيسم الثشلوني:}

يظهر أن جمهور النحويين قا اطمأنوا إلى التقسيم الثلاثي للكلمـة حتى صسار

إجماعًا

وقد حكي الإجمـاع عنهم الزجـاجي فقـال :"فأول مـا نــكر مـن ذلـك إجمـاع

النحويين على أن الكـلام اسم وفعل وحرف، وحقق القول بـذلك وسطره في كتابـه

سيبويه، والناس بعده غير منكرين عليه ذلك"(•) .

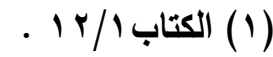

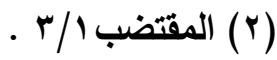

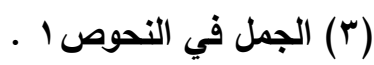

.

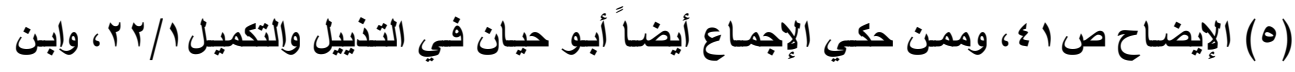


قال ابن السيد في معرض تعقبه الزجاجي : " أمـا تقسيمه الكلام ثلاثة أقسام

\section{فصحيح لا اعتراض فيه لمعترض" (1)}

وقد اجتهـ غير واحل من النحويين في بيـان علـة حصر الكلم في ثلاثنة

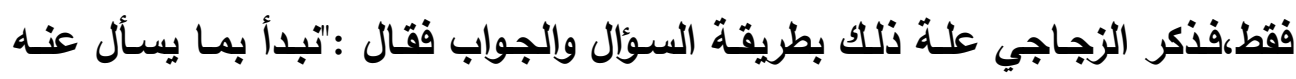

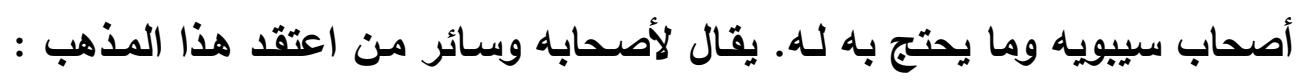

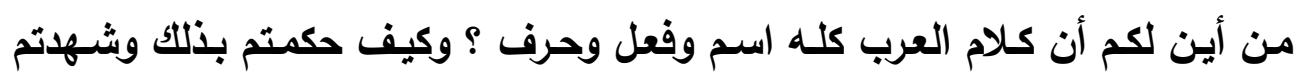

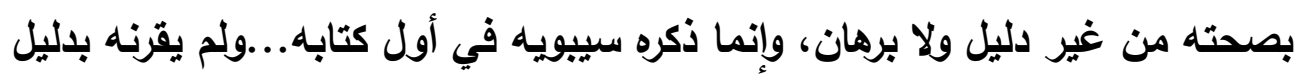

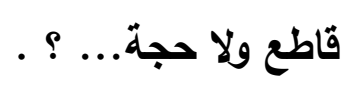

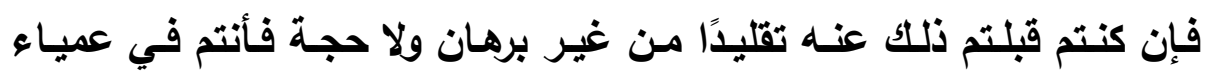

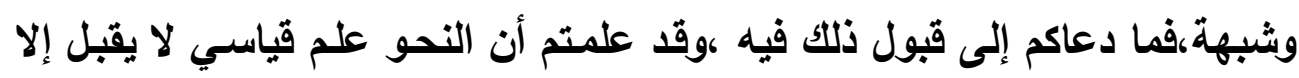

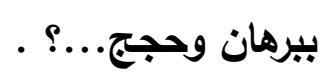

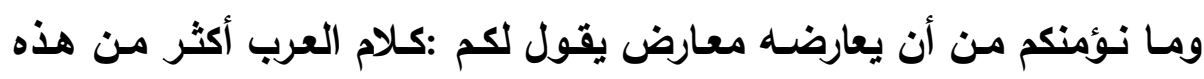

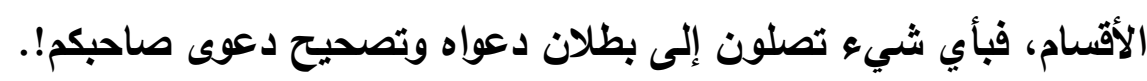

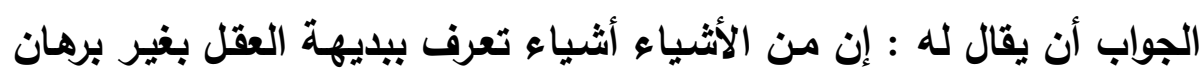

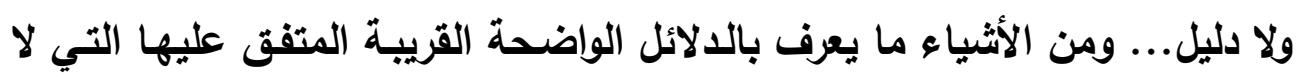
تثنكل على أحد. ونحن نعلم أن الله - عز وجل - إنما جعل الكلام ليعبر بـه العباد عما هجس

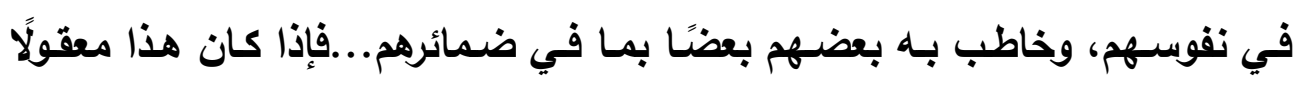

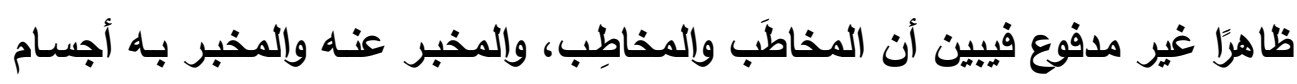

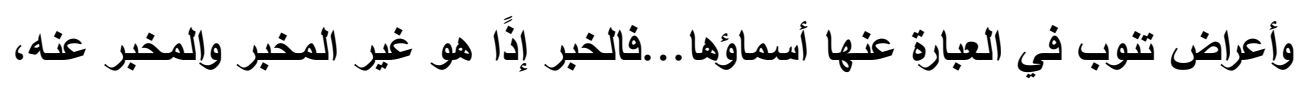
وهما داخلان تحت قسم الاسم، وإلخبر هو الفعل وما اشتق منه أو تضمن معناه. 
ولابد من رياط بينهما وهو الحرف، ولن يوجد إلى معنى رابع سبيل، فيكون

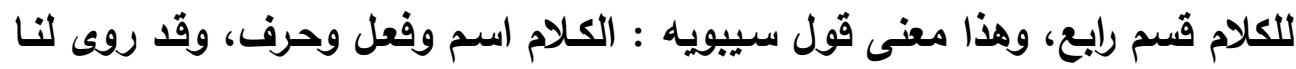

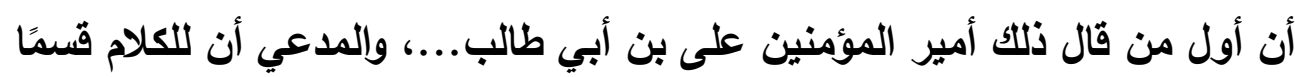

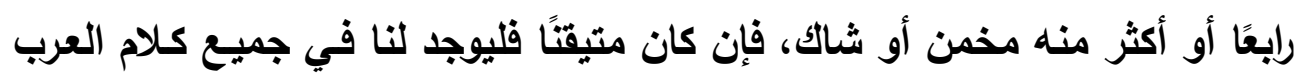

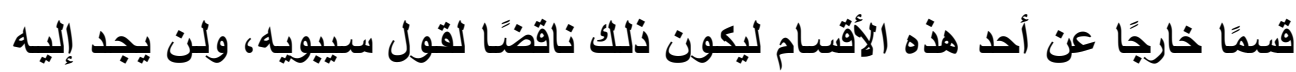

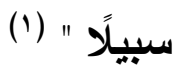

وقد لخص العكبري كلام الزجاجي بعبارة مختصرة واضحة حين قال:" إنما علم

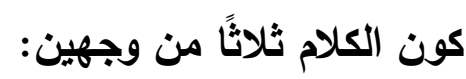

أحدهما : أن الكلام وضع للتعبير عن المعاني والمعاني ثلاثة : معنى يخبر

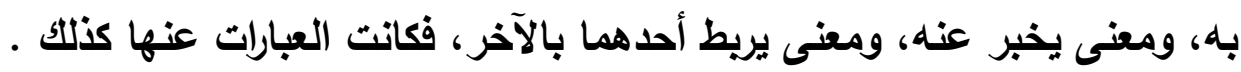

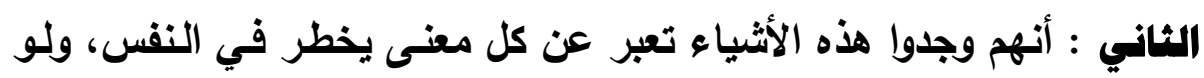

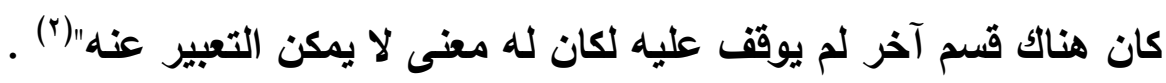
وقد استدل العيدرة على صحة هذه القسمة بالسماع والقياس والإجماع فقال

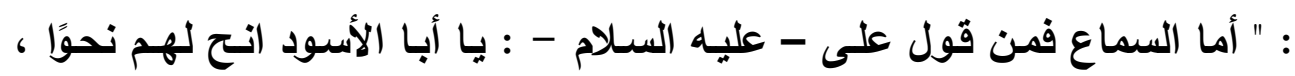

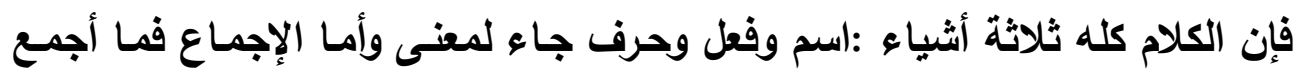

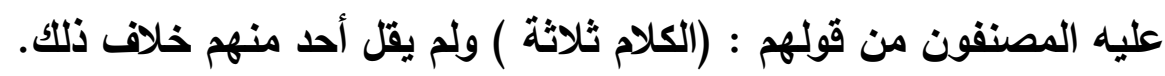

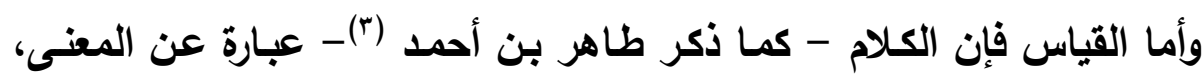

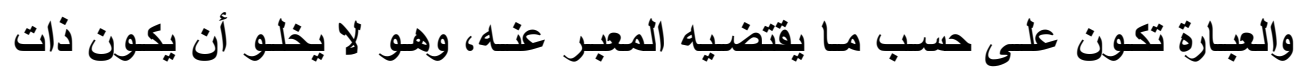

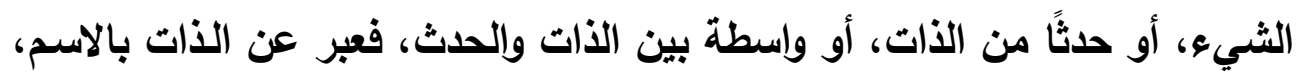

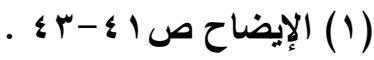

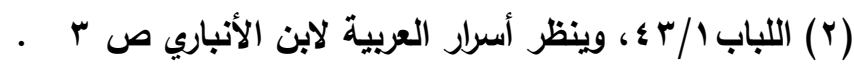

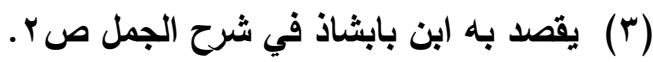


وعن الحدث بالفعل، وعن الواسطة بالحرف، فلو سقطت الذات لبقى الفعل بغير

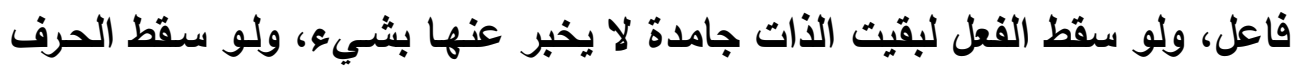

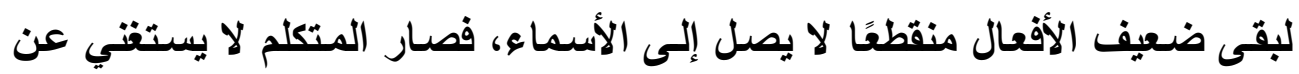

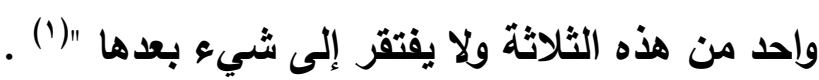

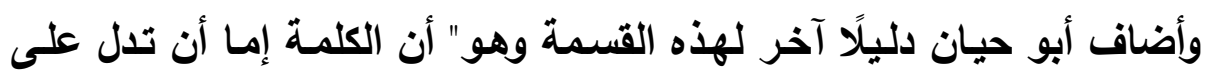

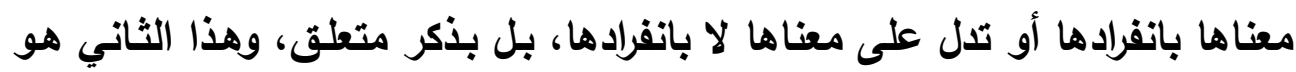

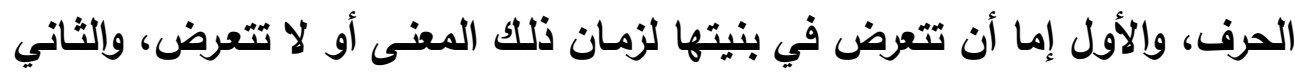

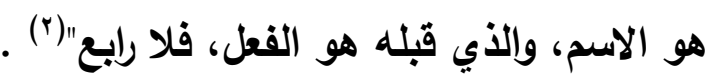

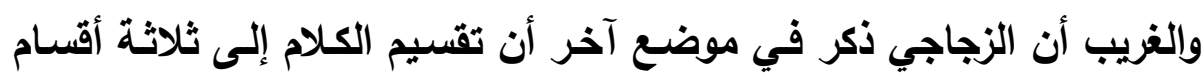

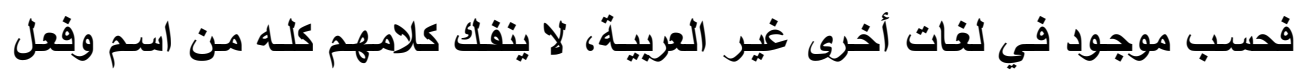

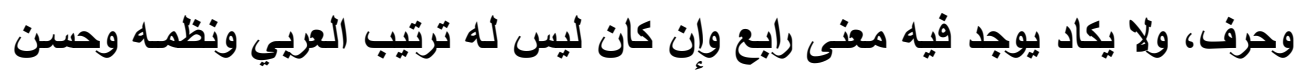
تأليفه (") وقد ظل هذا التقسيم الثلاثـي سـائدًا للدى النحويين باتفـاق إلا مـا لا يعتد

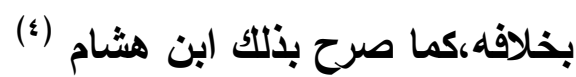
وقد صرح أبو حيان بذكر ذلك المخالف لإجماع النحويين على تلكك القسمة

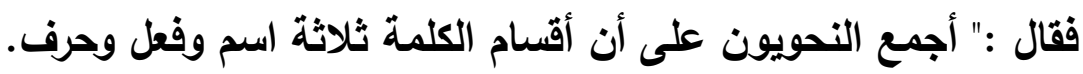

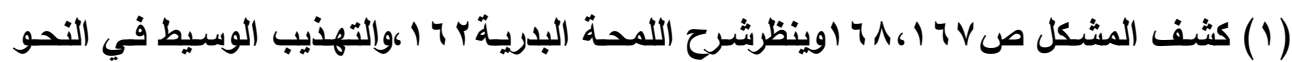

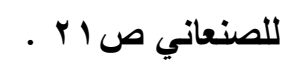

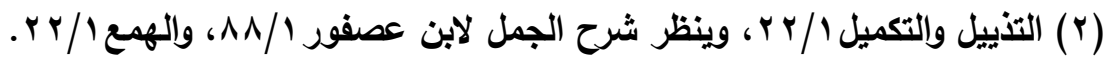

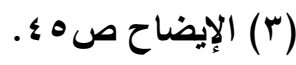

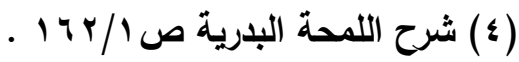


وحكى لنا الأستاذ أبو جعفر بن الزبير شيخنا عن صاحبه أبي جعفر بن صابر

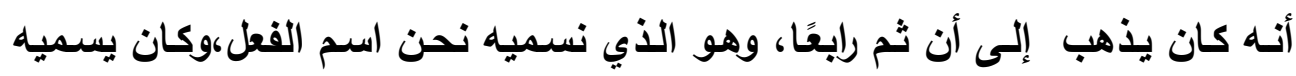
خالفة، إذ ليس هو عنده واحدًا من الثلاث" (1). وقد نقل أبو حيان عن شيخه ذلكك على سبيل الاستغراب والاستتدار لهذه المقالة .

والحـق أن ابـن صـابر حـين رأى أن اســم الفعـل مثـل : (مــه، وصــه،

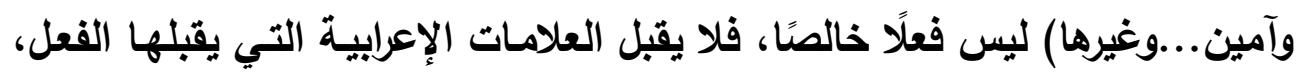
لكنه يدل على الحلث والزمان كما هو الحال في الفعل،كما أنها ليس اسمًا خالصنًا،

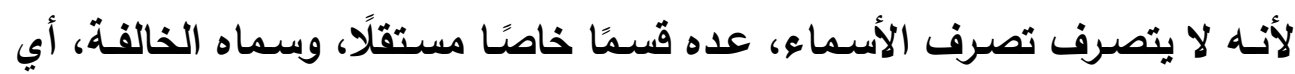

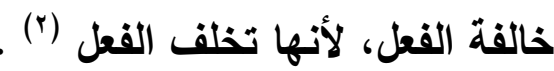
وقد فتح هذا باب الزيادة في القسمة للمحثين كما سنرى في المبحث الثاني ولتأرجح أسماء الأفعال بين الاسمية والفعلية اعتبرها البعض أفعالًا وعزي

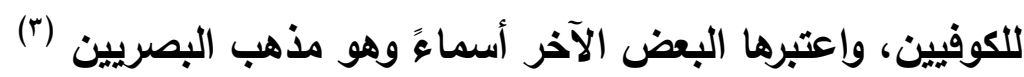

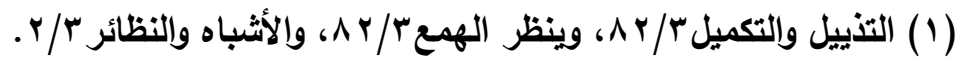

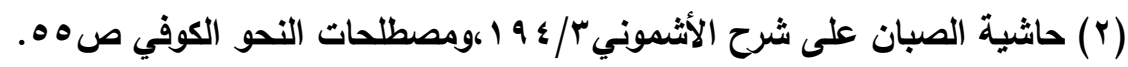

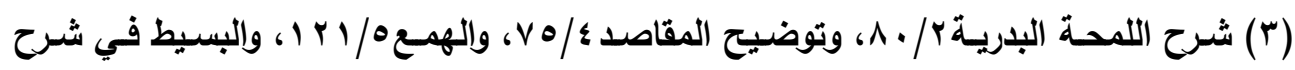

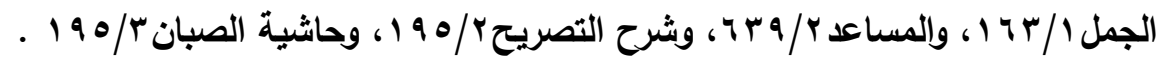


ونسب ابن هشام مصطلح الخالقة لبعض نحاة الأندلس (') .

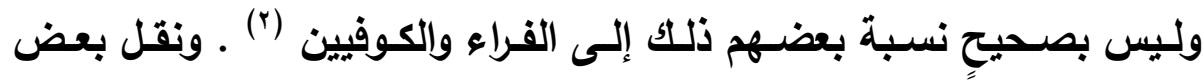

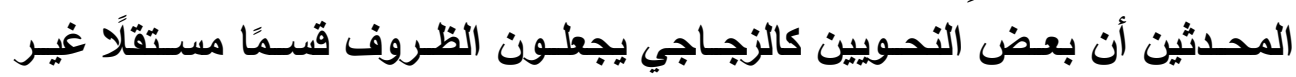

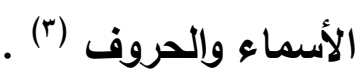

ولم أجد من ذهب إلى هذا الرأي صراحة وكلام الزجاجي في الجمل (؛) غير • صريح

وإن صح هذا العزو كان نواة للمحثين في تقسيمهم الجديد للكلمة . تمليل التزتيب الثلاثي :

جرى النحويون جميعهم على الاعتداد بهذا الترتيب الذي يبدأ بالاسم ويثني

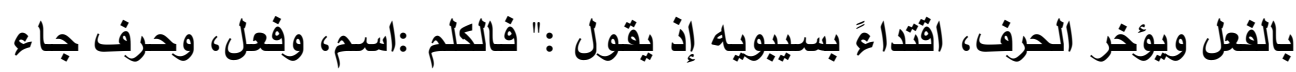

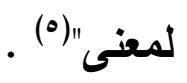
وقا حاول بعض النحويين ـ على عادتهم في اختراع العلل والولع بها ـ البحث

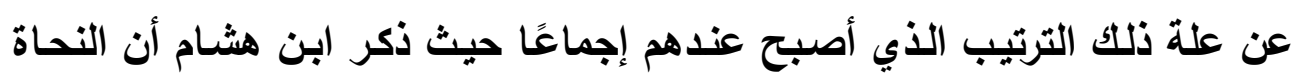

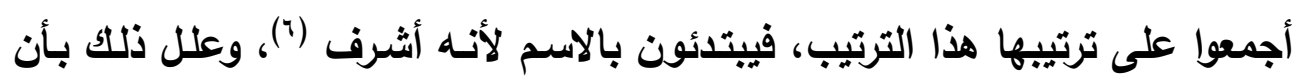

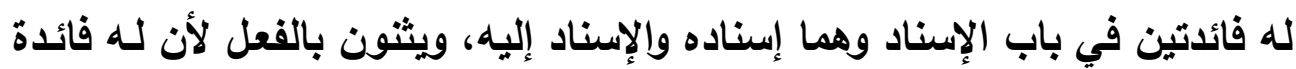

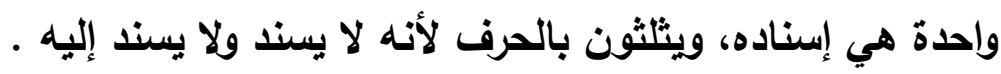

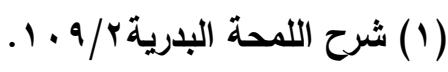

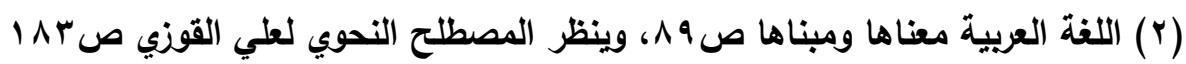

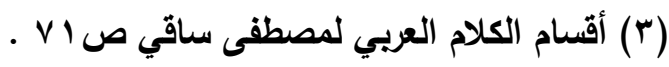

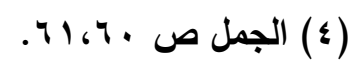

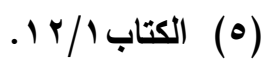

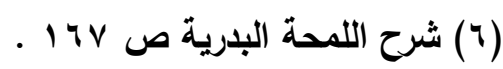


وقد تشابهت عبارات النحويين في تعليلهم تقديم الاسم وتأخير الحرف . فتكر الثمانيني بأن الاسم هو المقدم في الرتبة على قسيميه، لأنه الأصل لها حيث استغتي عن الفعل والحرف فعلا عليهما وأخر عنه الفعل لأنه فرع عليه، لأنـه يفتقر إلى تقدمه، وإنما أخر عنهما الحرف لأنه جاء لمعنيً في الاسم والفعل، فلمـا صار فرعًا عليهما تأخر (1) وعلل ابن الخشاب ذلك بعبارة موجزة فقال :"الحرف هو القسم الثالث من الكلم الثلاث ، وينحط عن رتبة الفعل كما انحط الفعل عن رتبة الاسم، وذلك أن الاسم يخبر عنه ويه كما علمت، والفعل يخبر بـه ولا يخبر عنـه، والحرف لا يخبر بـه ولا (r) " عie

وذكر ابن الأنباري في أسرار العربية مـا ذكره الثمانيني قبل، غير أنه زاد : " وإنما قدم الفعل على الحرف لأن الفعل يفيد مع الاسم نحو: قام زيـد، وأخر الحرف عن الفعل لأنه لا يفيد مع اسم واحد " (ז) وقد جعل الرضي الغاية من الترتيب حصول الفائدة وائتلاف الكلام حيث يقول : " إنما قام الاسم على الفعل والحرف لحصول الكـلام من نوعه دون أخويـه نحو زيد قائم والمقصود من معرفة الكلم الكلام والأحوال التي تعرض لـه من الإعراب وغيره ثم قدم الفعل على الحرف لأنـه وان لـ يأت من الفعلين كـلام كمـا تأتى من الاسمين لكنه يكون أحد جزئي الكلام نحو ضرب زيد بخـلاف الحرف فإنها لا يتأتى منه ومن كلمة أخرى كلام "(؛) .

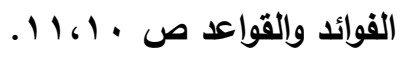

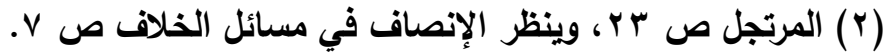

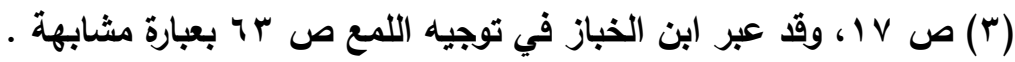

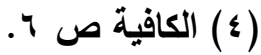


حروف المعاني ودلالتها في الكلام بين التراث النحوي واللاراسات النحوية الحديثة دراسة وصفية مقارنة د/ رشيد بن عبدالله الربيش

وهو بهذا يؤكل على شرف المعنى وأثره في صناعة النحو وتأليف الكلام .

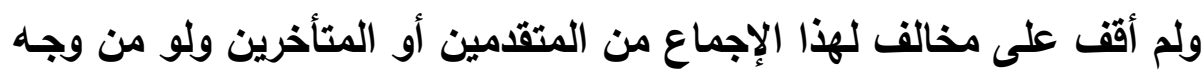

خفي، مما يدل على وجاهة تلك العلل ومتانتها وموافقتها لمقصود كلام العرب . 


\section{الإلب الثاني}

\section{هوضع مروف الإعاني من الكام عند النماة المدثين}

ظل التقسيم الثلاثـي للكغّم هو الاتجـاه السـائد والمتـوارث في بعض الكتب التعليمية حتى الآن، حيث عد بعض التحويين المحدثين هذا التقسيم الثُلاثي للكلم هو الأصح والأدق تأثرًا في ذلتك بمنهج النحاة القدماء. وممن ارتضى ذلك التقسيم وعمل بمقتضاه من المحدثين :

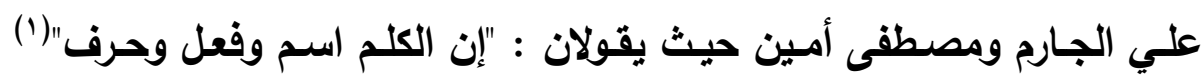
ومحمد عيد إذ يقول : "والاستقراء هو الأسـاس الذي أدى إلى معرفة أن الكلمـة

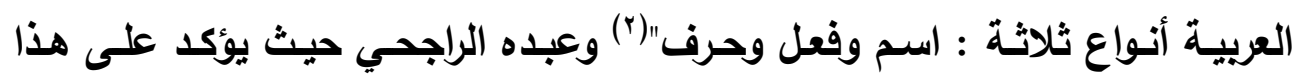
التقسيم بقوله : " وأنت تعلم أن الكلمة العربية إمـا أن تكون اسمًَا أو فعلًا أو حرفًا

فهي لا تخرج عن واحد من هذه الثلاثة"(") .

وممن سار على هذا النهج أيضًا عباس حسن(؛)، ومحمد خيز الحلواني (•)،

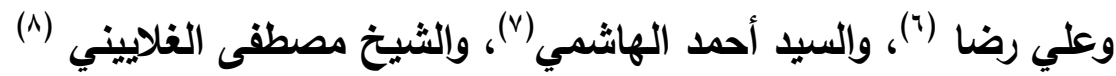

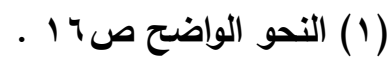

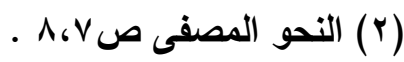

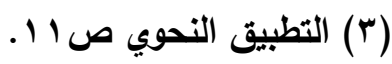

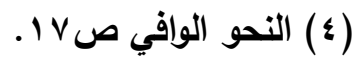

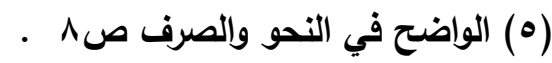

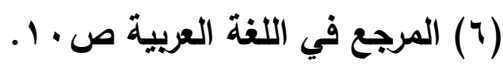

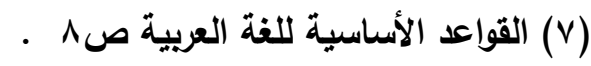

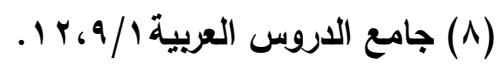


كما أن الاكتور شوقي ضيف وهو رائد من رواد التجديد في النحو العربي، قد ارتضى ذلك التقسيم الثلاثي والتزمسه في مشروعه التجديدي، فقال في حديثه عن

الكلمة وأقسامها: "وتنقسم إلى ثلاثة أقسام اسم وفعل وحرف..." (1) . آراك أخرى لبهض المدثثين في تقسيم الكلم : لم يلتزم بعض الدارسين بمـا اجتمعت عليه كلمـة النحاة القدماء والمحدثين حول تقسيم الكلم، فجـاءوا بتقسيمات مختلفـة للكلم، وثـاروا على التقسيم الثلاثي القديم لـزعمهم قصـوره عن الإحاطـة بفـروع الكـلام، وعدم استيفائه لمعـاني اللغـة

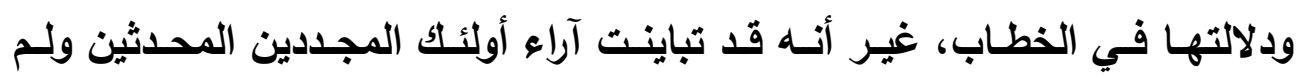
يجتمعوا على كلمة سواء في موقفهم من تقسيم الكلام، فسلكوا في ذلك طرائق قددا أهمها :

\section{1 - تقسيم يعقوب عبد النبي .}

يعد يعقوب عبد النبي من أوائل من تصدوا للنحو العربي بالنقا والتجديد، عبر

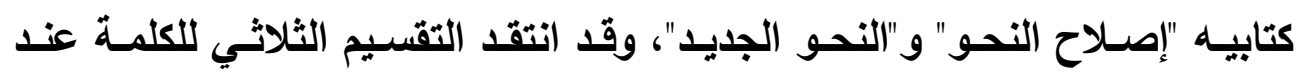
القدماء، وزعـم أنـه مـأخوذ عـن التقسيم السـرياني المـأخوذ بـدوره عـن التقسيم اليوناني.

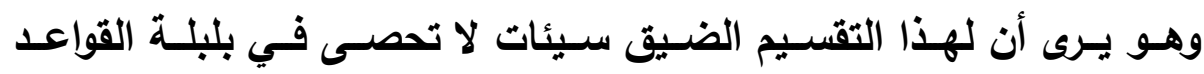

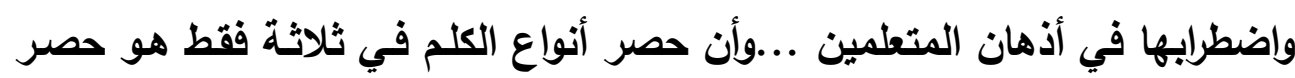
تعسفي وتقسيم باطل (r)

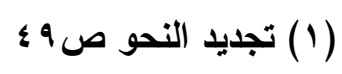

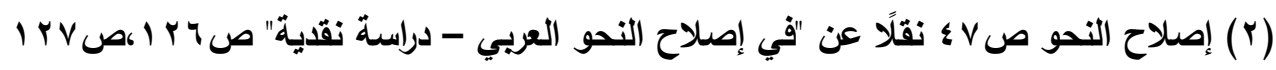

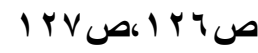


ومن هنا قسم الكلم إلى ثمانية أقسام هي (1) : ا- الاسسم : وهو ما دل على مسمى .

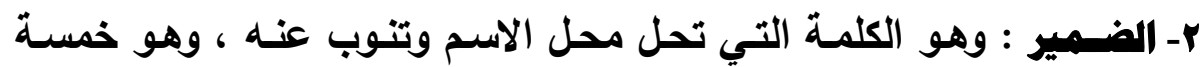

أنواع : (ضمير شخصي، وإشاري، وموصول، وشرطي، واستفهامي ) . r- الامدرر : وهو لفظ الحدث الجاري على الفعل •

ع- الصفات : وهى التي تدل على وصف وصاحبه ،وتؤخذ من ألفاظ الأفعال . ه- الظرف : وهو ما دل على زمان الفعل ومكانها . 1- الفمل : وهو ما دل على حدث وزمن وقبل التصرف . V- الهـرف : وهو مـا دل على معنى يظهر كاملًا في غيره ـ ثم أضساف في النحو الجديد نوعا آخر وهو: A- أسماء الأفعال والأصوات ، والأولى تؤدي معنى الأفعال وعملها ولا تتصرف مثلها والثانية هي ألفاظ محكية عن الإنسان (r) .. والملاحظ أن يعقوب عبد النبي لم يمس الحرف بأدنى تصرف أو تغيير لا من حيث المصطلح ولا من حيث دلالة الحرف وماهيته . في حين نجده قد تعرض للاسم وفرعه إلى أقسام تجاوز بها حدود مـا رسمه من هـ القدماء القاء r- تقسيم إبراهيم أنيس :

(1) والحقيقة أن هذا التقسيم بعينه هو ما أخذ به الدكتور تمام حسان في محاولته التجديدية في

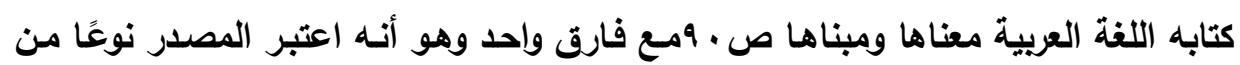

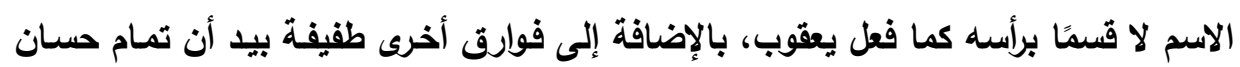

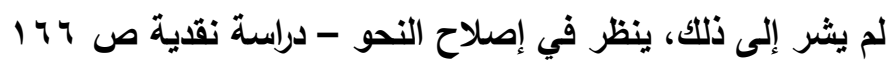

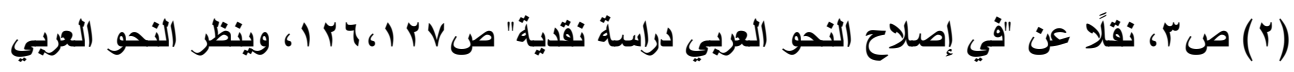

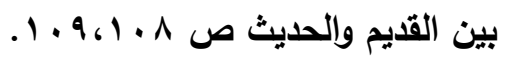


انتقل إبراهيم أنيس تقسيم القدماء للكلام، وزعم أنهم اضطريوا في تحديد هذه

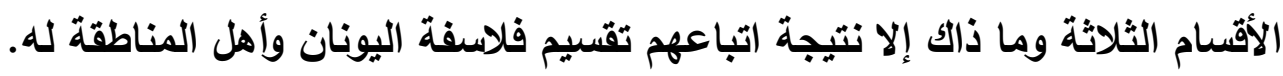

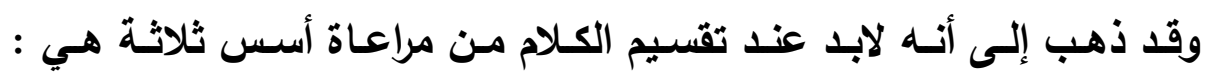

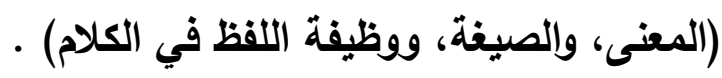

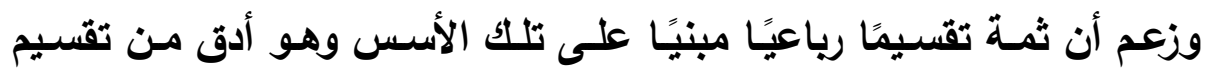

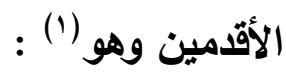
ا - الاســم : ويشـمل الاسم العـام أو الكلي كثـجرة وكتاب، والعلم مثل أحمد ومحمد، والصفة. r- الضمير: ويشمل إلى جانب الضمائر أسماء الإثـارة والأسماء الموصولة والأعداد. r- الفعل : وعلاماتهه دخول (قد) والسين وسوف عليه،واتصال ضمير الرفع ع- الأداة : ويندرج تحتها كل ما بقى من ألفاظ اللغة مما لم يذكر في الأقسام

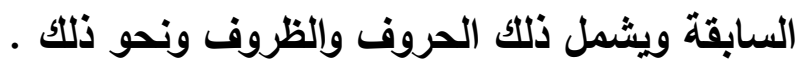

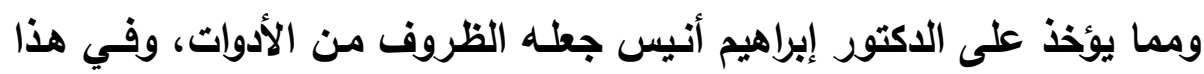
نظر لوجود فوارق أسلويية لا سبيل إلى تجاهلها بين الظروف ويقية الأدوات(ب) .

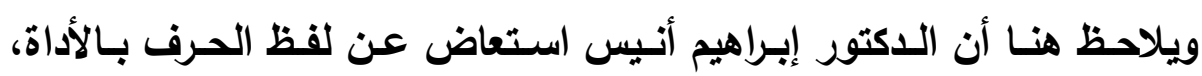
ومصطلح الأداة مصطلح قديم كما ذكر في تمهيد هذا البحث، غير أن أنيس أدخل

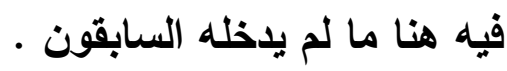

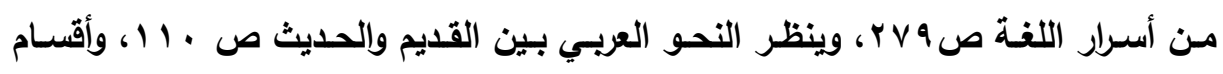

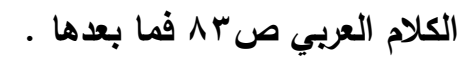

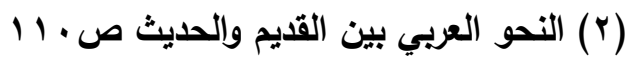




\section{r- تقسيم مدندي المغرومي :}

انتقد الدكتور مهدي المخزومسي تقسيم سييويه والقدماء للكلمـة (اسـم وفعل

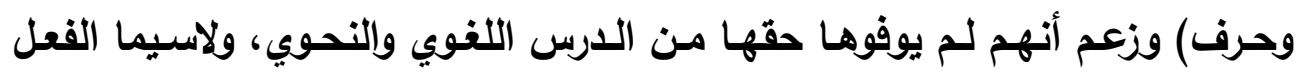
والأداة، وذلك بسبب التزامهم التام بنظرية العامل : "...فقد غبر القوم متشبثين بهذا التقسيم الثلاثي حتى بـا وكأنـه تقسيم أمسلاه حكم العقل عليهم، ولكن الأمـر يبدو على غير مـا توهموا، فهنـاك كلمـات لا ينطبق عليها تعريـف الأسـماء ولا تعريـف الأفعال ولا تعريف الأدوات، ولـم يعرض لها سييويه أو يشر إليها في تقسيمه أو ينص عليها في تمثيله لأقتسام الكلمـة،كلمات ليس لها معنى خاص ولا مـلول بعينه،كلمات مبهمة تطلق على الموجودات كلها، ولا تدل على معنى دلالـة الاسم على مسماه، كما يدل (رجل) على إنسان ذكر لا بعينه، و(امرأة) على إنسـانة أنثى لا بعينها، و(شجرة) على نبتة ذات ساق إلى غير ذلك، ولكنها تستعمل في هذا كلـه

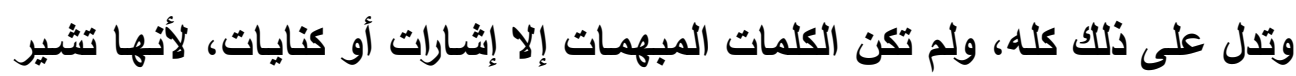
إلى كل ذلك ويكنى بها عن كل ذلك . وإذا كان الأمر كذلك فجدير بنا أن نقسم الكلم إلى أريعة أقسام بدلًا من ثلاثة، مما جرى عليه عرف النحاة قديمًا وحديثًا وهي :

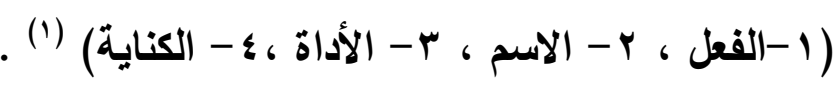

والملاحظ عليه في هذا التقسيم أنه قدم الفعل على الاسم خلافًا لمـا هو شـائع ومتبع عند القدماء والمحدثين، بالرغم من أنه بين ما للاسم في الجملة من أهمية غير خافية على الارسين واختصاصه بخصائص ينفرد بها عما سواه ومن أجل هذا

ينبغي- عنده- أن تنال الأسماء من الدارسين فضل عناية (ץ) .

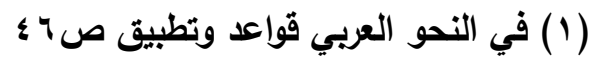

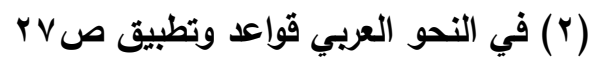


وصرح بأنه أراد بالأداة مـا أراده الكوفيون مرادفًا لمصطلح الحرف الذي عبر

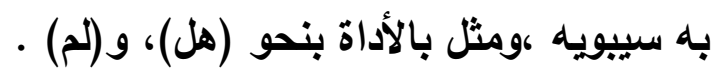

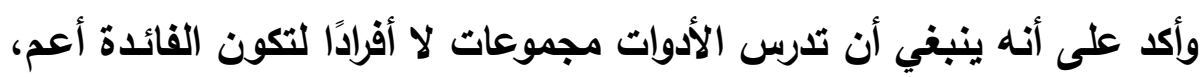

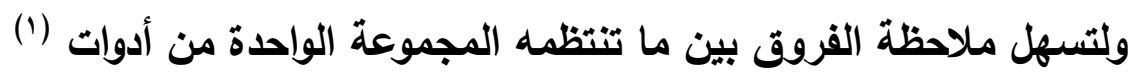
غير أنها يؤخذ على المخزومي أنه عند حليثه عن القسم الرابع (الكنايات)

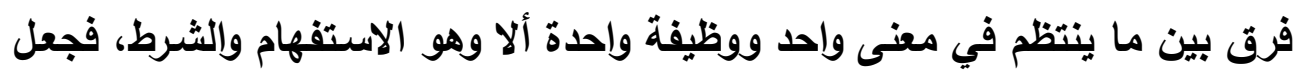

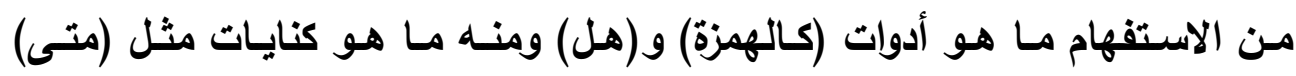

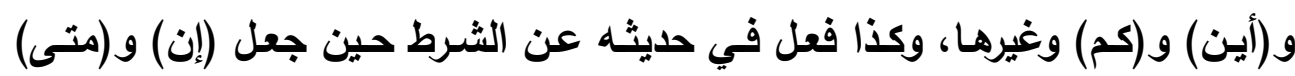

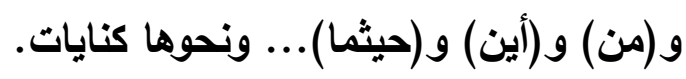

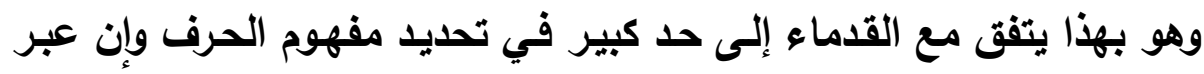

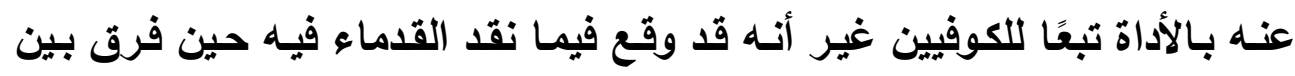

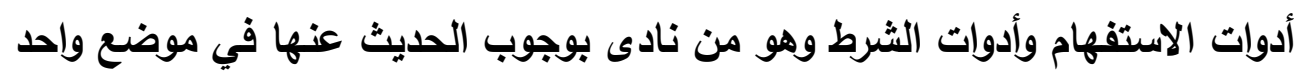
كما سلف . الف

\section{ع- تقسيم الدكتور هممد مهاسة عبد الطيف :}

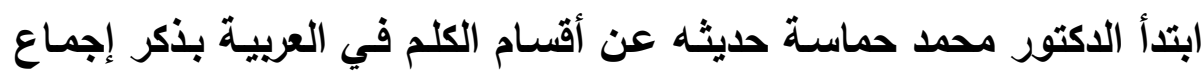

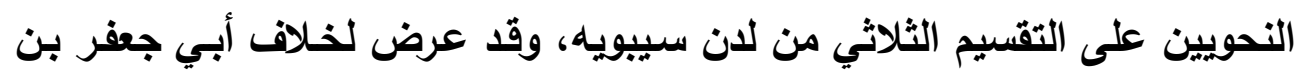

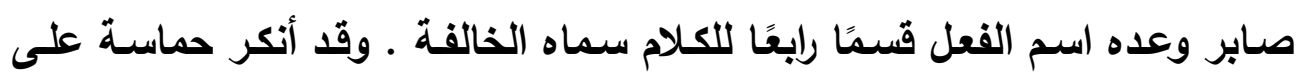

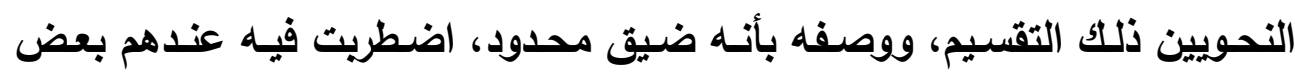

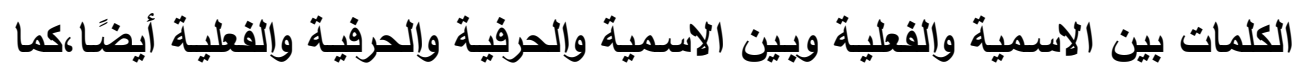

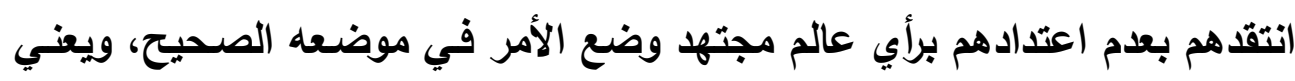
به ابن صابر • ويناء على ذلك الاضطراب للى القدماء فإن التقسيم العلمي الذي فئي

(1) (المرجع السابق ص ^ץ (1) - (1) 
يرمي إليه الباحث لابد أن يكون خاضعًا لقانون الحالات الموضوعية، والتقسيمات

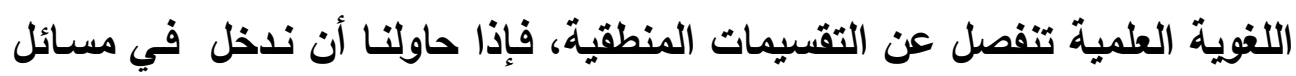
النحو شيئًا من النظام المنطقي رأينا أنفسنا منساقين إلى توزيعها تونيات توزيعًا تحكميًا،

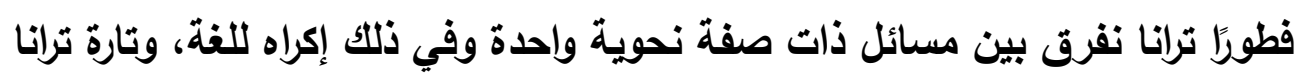

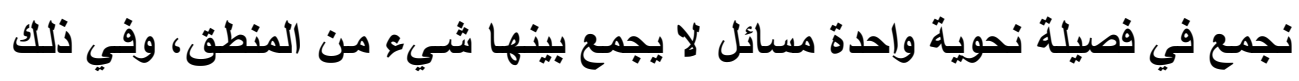
إكراه للعقل . وقد نقل حماسـة نقد الدارسين المحدثين النحاة القدماء لتأثرهم في تقسيم الكلمة بالفلسفة الإغريقية، لذا جاء تقسيمهم غير دقيق، لأنه لا يستوعب كل أجزاء الكلام، وعليه فلابد من إعادة النظر في تقسيم الكلمة . وقد عرض بالتفصيل لثلاث محاولات لتقسيم الكلمة هي أولاها محاولة الدكتور

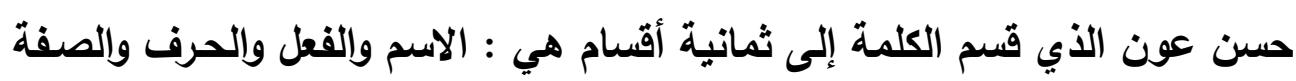

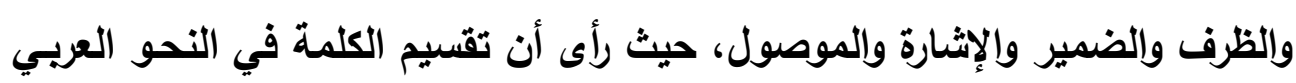
متخلف، وفي حاجة ملحة إلى النظر والاستدراك، وأن لتقسيمه الجديد مزايا أهمها :

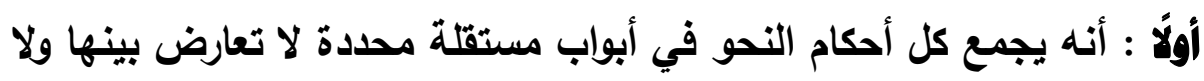
تداخل .

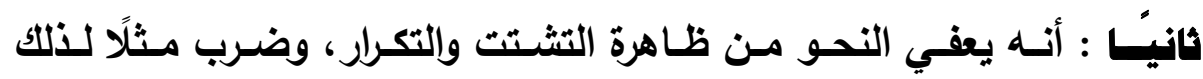
بالحروف التي تحدث عنها القدماء في أبواب متفرقة .

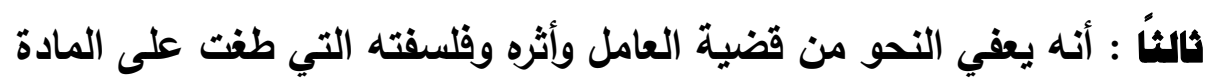
النحوية . وقد انتقد حماسة حسن عون في أنها لم يحدد كل قسم من أقسام الكلمـة ،

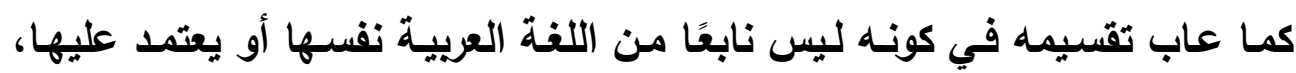


ولكنـه تقسيم بالقبـاس إلى اللغـات الأخرى كاليونانيـة واللاتينيـة ارتضـاه للعربيـة(1)، وتقسيم الكلمة ينبغي أن يكون قائمًا على خصائص اللغة المدروسة نفسها ـ أمسا المحاولتان الأخريـان فهما محاولة الدكتور إبراهيم أنيس والدكتور تمـام حسان وق تم تخصيص هاتين المحاولتين في هذا البحث بما يغتي عن التكرار . وقد بـين حماسـة في ثنايـا كتابـه التقسيم الذي سـيعتمد عليـه وهـو تقسيم الاكتور تمام حسان الآتي ذكره، لوضوح الأسس التي استتد إليها وتتوعها، غير أنه خالفـه في عدم عد الظروف قسـمًا قائمًَا بذاتـه، ورأى أن تضـم لـلأدوات، لأنهـا

تستخدم أيضًا في الريط بين أجزاء الجملة والتعليق (r) . ه- تقسيم الدكتور تمام هسان :

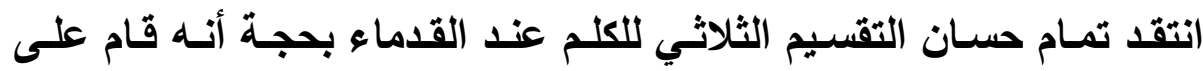
التفريق على أساس من المبنى فقط، أو المعنى فقط، وأمثل الطرق أن يتم التفريق على أسساس من الاعتبارين مجتمعين، وعليه فإن ذلك التقسيم بحاجة إلى إعادة النظر، ومحاولـة التعديل بإنشـاء تقسيم آخر جديد مبني على استخدام أكثر دقة

لاعتباري المبنى وإلمعنى (") . وقد قسم الاكتور تمام حسان الكلم أولًا على أربعة أقسام فقط وهى : (الاسم

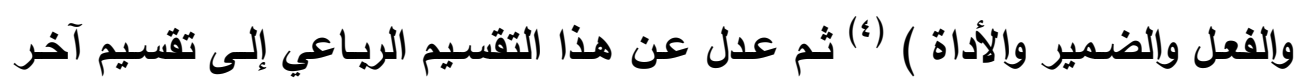

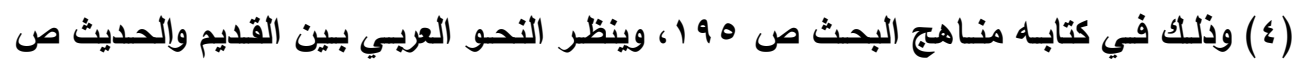

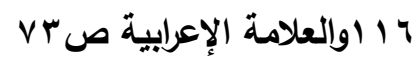


سباعي، إذ قسم الكلم إلى سبعة أقسـام هـي : (الاسـم والصفة والفعل والخالفـة

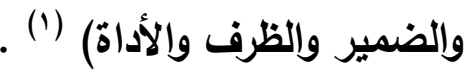

وقد اعتمد في هذا التقسيم على أساس المبنى والمعنى معًا، وهو أساس يقوم على الثكل الإملائي المكتوب، والتوزيع الصرفي، والأسس السياقية، والمعنى الأعم

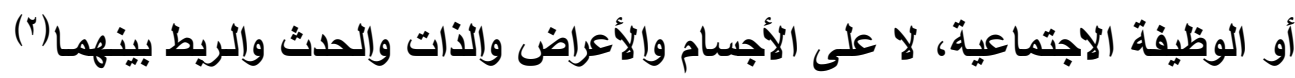

ويرى تمام أنه يجب بناء ذلك التقسيم على طائفة من المباني والمعاني حددها فيما يلي: أ- المباني : وهى عنده الصورة الإعرابية والرتبة والصيفة والجدول والإلصاق

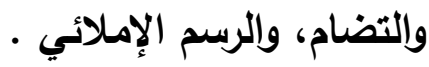
ب- المعساني : وهـى عنده التسـمية، والحسدث، والـزمن، والتعليق، والمعنى الجملي. والذي يهمنـا من ذلكك التقسيم هو حديثه عن الأدوات، ويتضـح منـه اتسـاع

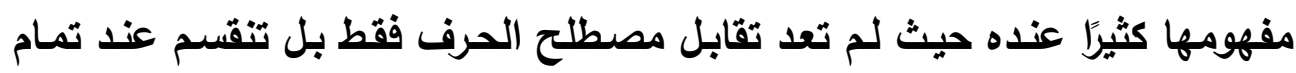
حسان إلى قسمين : ا - الأداة الأصلية : وهى الحروف ذات المعاني كحروف الجر والنسـخ والعطف

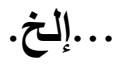

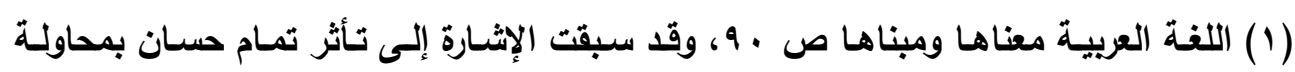

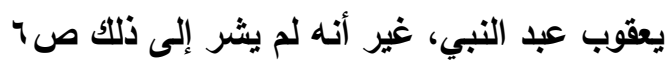

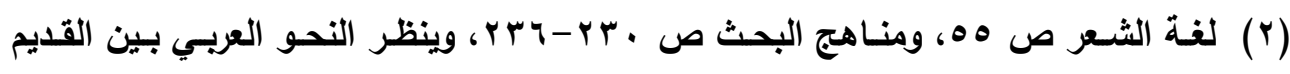
والحيث ص17 (11) 
r- الأداة المحولة : وقد تكون هذه ظرفية إذ تستعمل الظروف في تعليق جمل

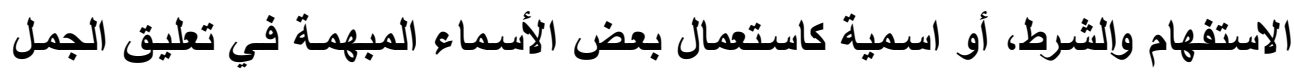
مثل كم وكيف في الاستفهام وإلتكثير وإلثرط أيضًا، أو فعلية لتحويل بعض الأيفاء الأفعال

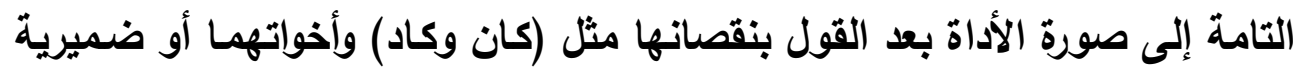

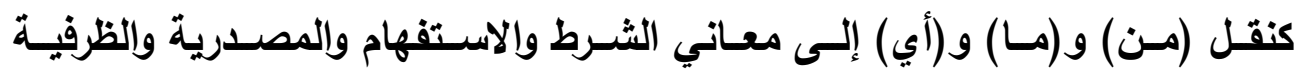
والتعبب...إلخ (') (بن)

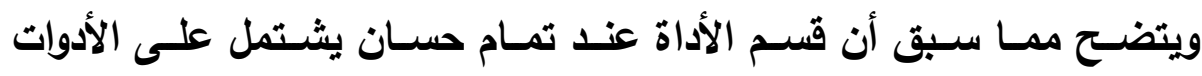

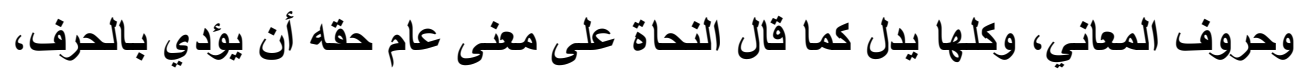

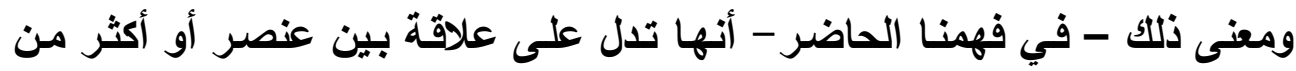
عناصر السياق (ץ) أما أسباب إخراجه الأفعال الناقصة (كان وكاد) وأخواتهما من الأفعال وإدخالها

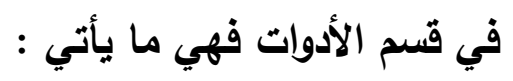

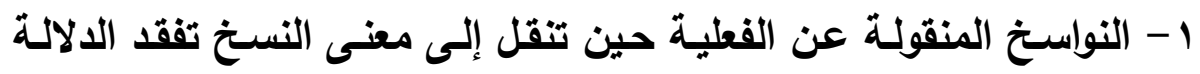

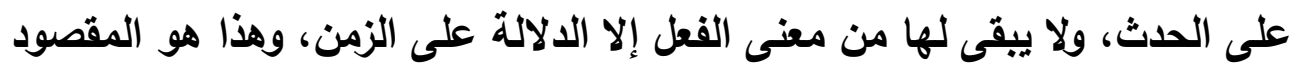

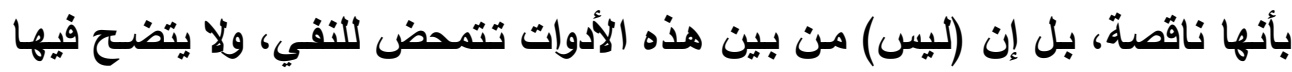

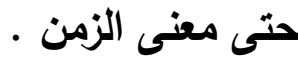
ץ - لا يوجد معنى الإسناد بين هذه الأدوات ومرفوعاتها، ولكن هذا المعنى

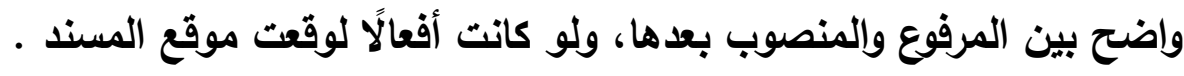

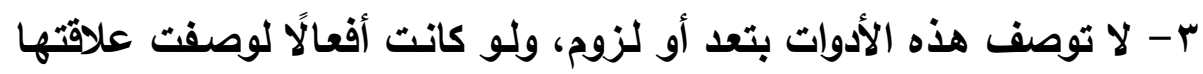

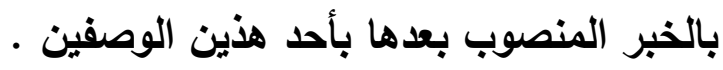

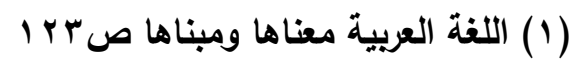

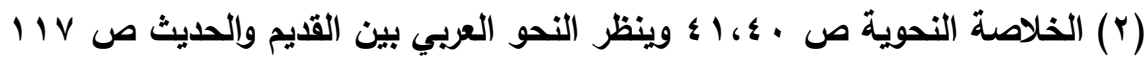


؛ - بعض هذه الأدوات مثل (ليس وعسى وإخولق) وأفعال الثروع إما غير

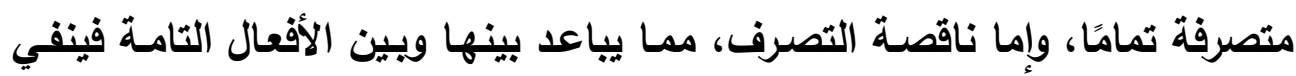
عنها صفة الفعلية أو يضعفها. ه - تختص هذه النواستخ بالـخول على الأفعال، فتعتبر قرائن وتدل على أنى

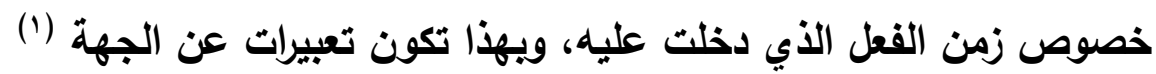

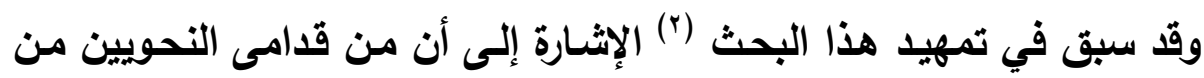

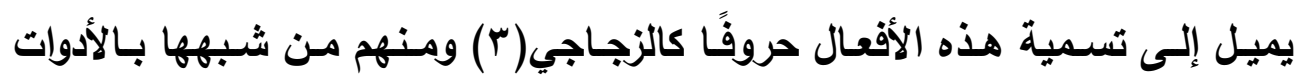

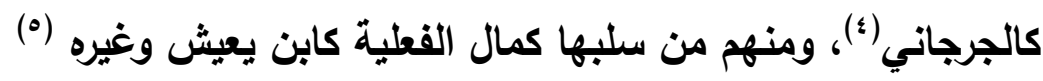

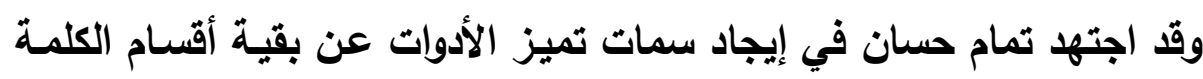

فنكر منها : ا - من حيث الرتبة، الأدوات أثشد تأصلًا فيها من الضمائر ،كما أن الصدارة

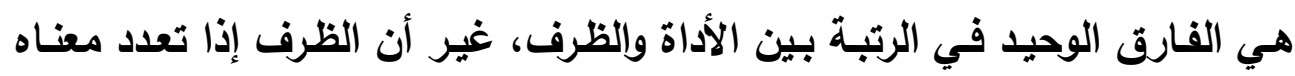

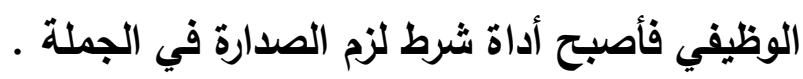

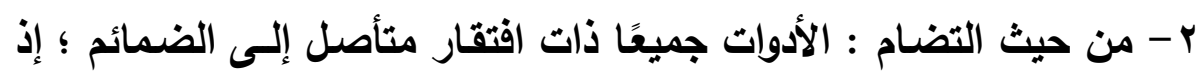

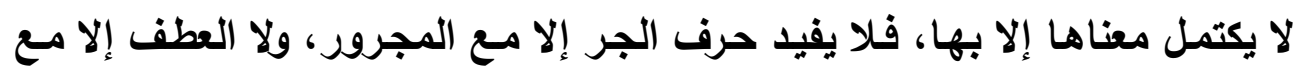

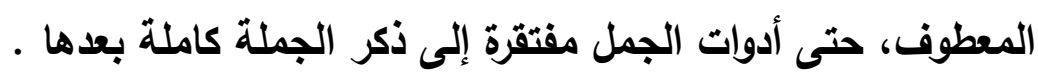

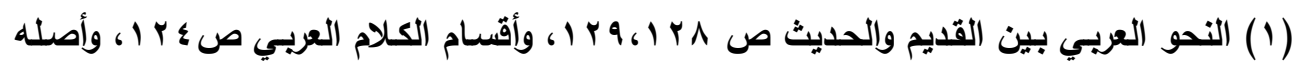

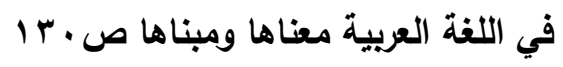

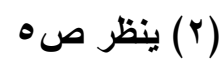

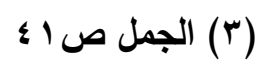

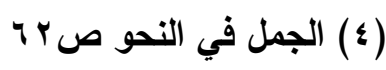

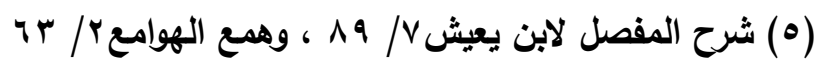
$r \leq$. 
ب- مـن حيـ الرسـم الإملائسي : فـالأدوات كالضـمائر منهـا المنفصل ومنهـا المتصل، فإذا كانت الأداة على حرف واحد كانت متصلة بما بعدها كباء الجر ولامه، أمسا إذا جاءت الأداة على أكثر من حرف فإنها تتفصل عن ضميمتها مثل (عن جرن وعلى)، فأما منه وعنه وعليه فالوصل للضمير لا لـلأداة، فلمجيئه على حرف واحد

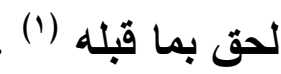

تلك كانت روئة تمام حسان في الأداة ووظيفتها وموضعها من أقسام الكلام، وهي روية جريئة وجديدة جديرة بالاحتفاء، وإن اختلف معه في بعض نتائجها فهي بحق إضافة نوعية في حقل الدراسات النحوية الحديثة . هذه أبرز الآراء في تقسيم الكـلام عند المحدثين، وللدكتور فاضل مصطفى السـاقي دراسـة مستقلة في أقسـام الكـلام العريسي، حيث تناولها من حيـث الشـكل والوظيفة، غير أنه لا يعدو أن عرض لأبرز تلك المحاولات، وتبنى منها رأى الاكتور تمام حسان السالف ذكره وليس لله في هذه الدراسـة - حسب تقديري - غير فضل جمع ما تناثز من أقوال وآراء أولئك العلماء، وردد ما باحوا بـه من نقد القدماء في تقسيم الكلام وأنهم بذلك قد تأثروا بالقلسفة، ومن هنا تداخلت عندهم تلك الأقسـام فوقعوا في كثير من الحيرة والاضطراب على حد زعمـه، غير أنسه قد أشـاد بجهود الجرجاني وإنفراده بـآراء خاصـة تتمثل في نظريـة النظم ومـا يتصل بها من بنـاء وترتيب وتعليق، ودعا إلى إعادة النظر في التقسيم التثلاثي كما هي دعوة من سبقه أيضًا

وقد خلص إلى نتائج مستخلصة من اضطراب أقوال التحاة حسب تعبيره منها

1 - أنه يميل إلى جعل الخالفة قسمًا رابعًا من أقسام الكلام .

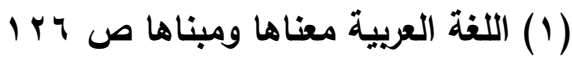


r- أنـه يميل إلى مـا ذكره بعض النــاة كالزجـاجي مـن أن الظروف غير

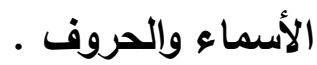

r- أنه يميل إلى الأخذ بتسمية الكوفيين للحروف أدوات، لأنها في نظره أقرب

إلى الدقة، لتشمل حروف المعاني ويقية الأدوات التي تؤدي وظيفة التعليق .

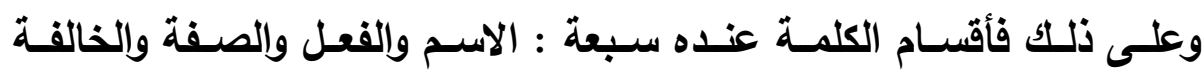
والضـمير والظرف والأداة (1) وهـو بهـام التقسيم تـابع لأستاذه تمسام حسـان تمسام المتابعة .

1 - أقسام الكلام العربي ص V Tما بعدها 


\section{المبمث الثاني}

\section{دلالة هروف المعاني عند القدماك والمدثين}

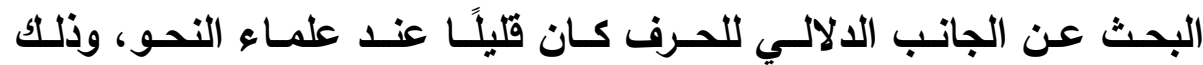
لانشـالهم في تحديــ مفهوم الحـرف مسن خـلال تقسيم الكلمـة ، وحصـر ذلـك

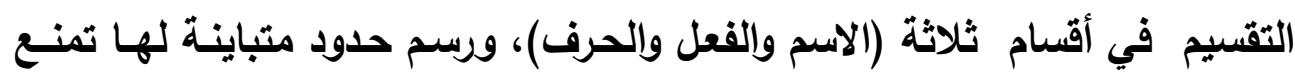
تداخلها ، وكان حديثهم عن معاني الحروف ودلالاتها مفردة، مجردة من التركيب

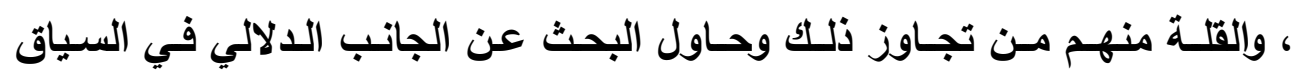
كالجرجاني مثلًا في جهوده البلاغية . وكان للبلاغيين جهود متنـاثرة في الحديث عن دلالـة حروف المعاني في السياق وأثرها فيما يعرف بالانسجام والاتسـاق، خاصـة في مبحثي الوصل والفصل

أمـا الأصوليون فقد كـان للبحث في الجانب الدلالـي للحرف نصيب الأسد عندهم، انطلاقًا من خدمة النص القرآني والحديث الثريف ، مسن خـلال البحث عن فن دلالات الحـروف ووظائفهـا لتحليـل الجوانـب اللغويـة فـي القـرآن والسنــة، و فهـم أسـاليبهما البياتيـة واسـتباط أحكامهمـا التشـريعية،ومحاولة إدراك مقاصدهما، وكل ذلك لأن منهج علمـاء الأصول هو الكشـف عـن المعاني بجميع صورها الجليـة والغامضة محاولة للوصول للمقاصد (r)

(1) دلائسل الإعجـاز للجرجـاني ص • V اومابعدها، ويغيـة الإيضـاح للصـعيدي ص ب آومابعدها،

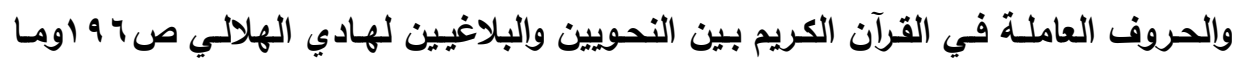

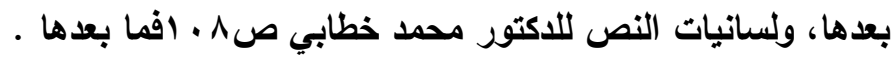

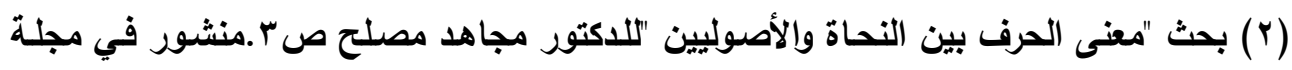

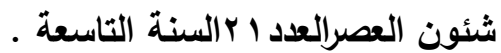


حروف المعاني ودلالتها في الكلام بين التراث النحوي والداسات النحوية الحديثة دراسة وصفية مقارنة د/ رشيد بن عبدالله الربيش

ولما كانت هذه الاراسة نحويـة، فسأكتفي باستعراض آراء علمـاء النحو حول

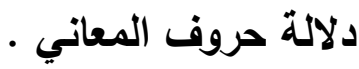




\section{الالماب الأول}

\section{آراء النمويين القدمهاs}

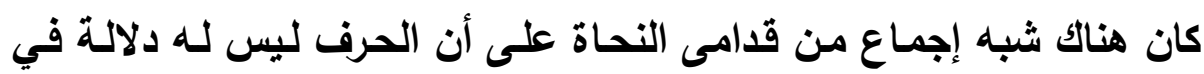

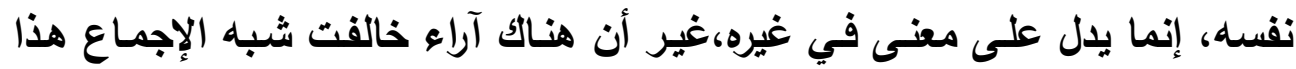

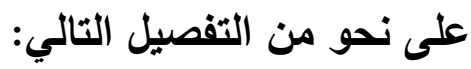

أولا:القائلون بلالة الحرف على مغني في غيره وهم جمهور النحاة:

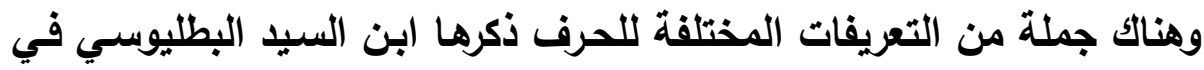

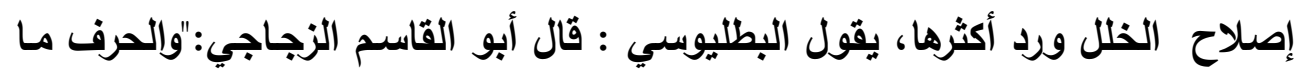

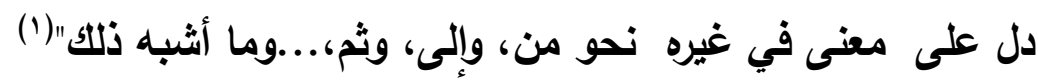

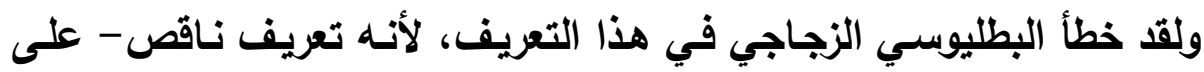
حد قول البطليوسي - و لا تستقيم صحته حتى يزاد فيه (ولم يكن أحد جزأي الجملة

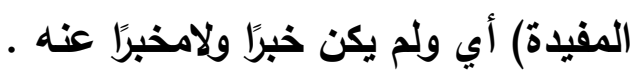
ونقل البطليوسي تعريف سيبويه الحرف بأنه : "ما جاء لمعنى ليس باسم ولا

فعل" (r) (9) ثم وصف حد سيبويه بأنه: " أتم التعريفات فائدة ولو يدخله الخلل" . وذكر البطليوسي أيضًا تعريف الأخفش :"الحرف مـا لـم يحسن لـه الفعل ولا الصفة ولا التثية ولا الجمع ولم يجز أن يتصرف" (") . ورد عليه قائلًا : "خطأ لأن الفعل داخل في هذا التحديد فمن الأفعال مـا لا يتصرف، مثل، نعم، ويئس، وعسى، وكذلك أسماء الأفعال،صه، ومه......وغيرها " .

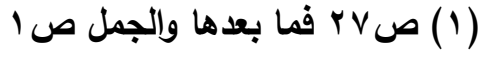

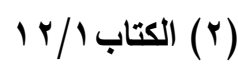

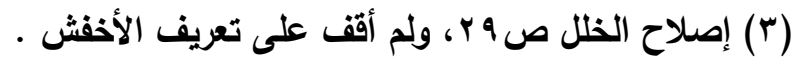


كما نقل تعريف المبرد :"الحرف ما كان موصلًا الفعل إلى اسم، أو عاطفًا أو تابعًا لتحدث به معرفة، أو كان عاملًا ".

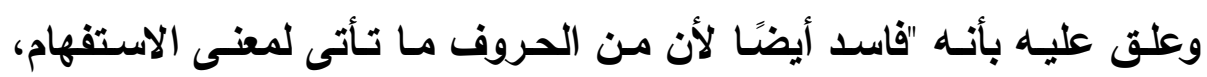

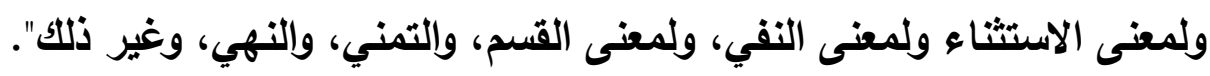

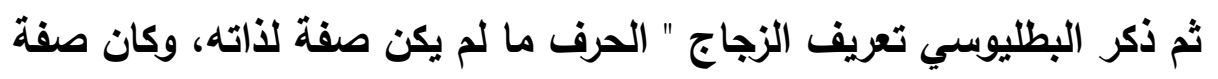

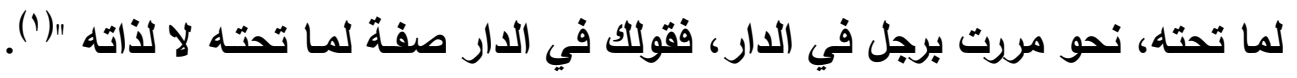

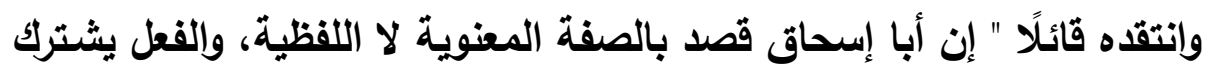

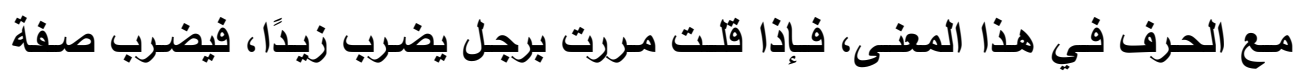

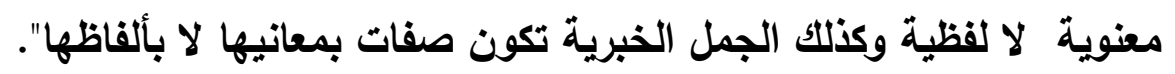

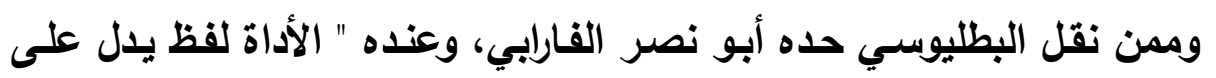

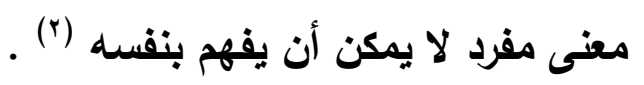
وعلق البطليوسي على ذلكـ بقولهه " لقد حده دون أن يقرنسه باسم أو كلمـة وهذا تحديد صحيح " وشبهه بتعريف سييويه وتابعه عليه. وهناك أقوال أخرى تذهب في دلالة الحرف هذا المذهب أذكر منها أبرزها :

(1) المرجع السابق 9 r، ولم أقف على تعريف الزجاج في كتبه .

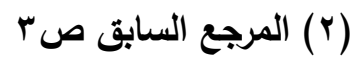




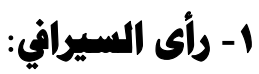

قال شارحًا تعريف سيبويه للحرف " فالكلم اسم،وفعل وحرف جاء لمعنى"( "). فإن سـأل سـائل فقال :لم قال :(وحرف جاء لمعنى) فقد علمنـا أن الأسـماء والأفعال جئن لمعان، قيل له، إنما أراد وحرف جاء لمعنى في الاسم والفعل".

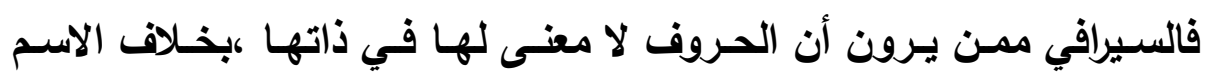

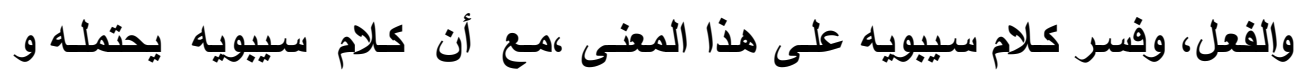

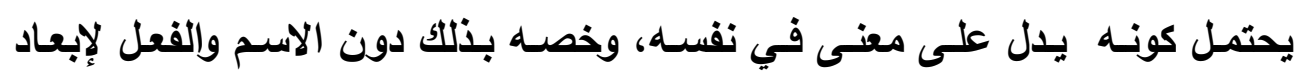
حروف المباني، والتأكيا على حروف المعاني كقسيمة للاسم والفعل. وقد استرسل السيرافي في تعليل مـا ذهب إلبه من دلالة الاسم والفعل على

معان في نفسيهما بخلاف الحرف (r) . وذكر وجوهاً أخرى محتملة لكلام سيويه عن الحرف لا تخرج عن فهمهـ

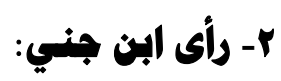

قال:"والحرف ما لم تحسن فيه علامات الأسماء ولا علامات الأفقال وإنما جاء

$$
\begin{aligned}
& \text { لمعنى في غيره"("َ) . } \\
& \text { r- رأى الزومفشري: }
\end{aligned}
$$

قال :"الحرف هو ما دل على معنى في غيره،ومن ثم لا ينقك من اسم أو فعل يصحبه، إلا في مواضع مخصوصـة حذف فيها الفعل واقتصر على الحرف فجرى مجرى النائب"(؛) .

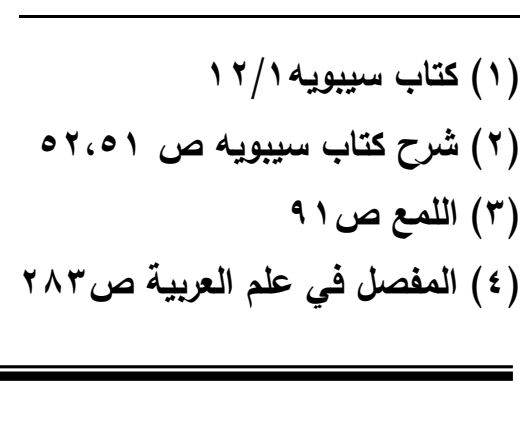


ويقصد بذلك ياء النداء.

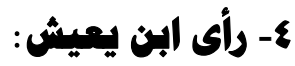

قام ابن يعيش بشرح رأى الزمخشري في الحرف فقال : " ....وقولنا دلت على معنى في غيرها فصل ميزه- أي الحرف- عن الاسم والفعل إذ معنى الاسم والفعل

في أنفسهما، ومعنى الحرف في غيره".(1)

ثم مثل على ذلك بكلمة (الغلام) وأنـه قد فهم منها المعرفة،ولكن إذا ذإكرت (أل) مفردة، لا يفهم منها معنى، وإذا قرنت بما بعدها من اسم أفادت التعريف فيـه، وهذا معنى دلالتها في غيرها. 1أى المرادي:

قال:"ولقد حد الحرف بحدود كثيرة ومن أحسنها قول بعضهم : الحرف كلمـة تلدل على معنى في غيرها". ثم فسر ذلك بقوله: "إن دلالة الحرف على معناه الإفرادي متوقفة على

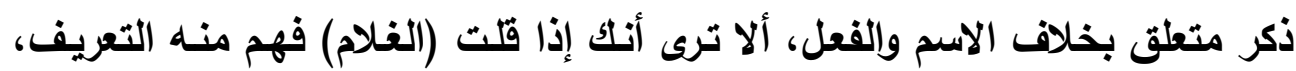
ولو قلت (أل) مفردة، لم يفهم منه معنى، فإذا قرن بالاسم أفاد التعريف وكذلك ياء الجر فإنها تلال على الإلصاق حتى تضاف إلي الاسم الأي بعدها...وكذلك القول في

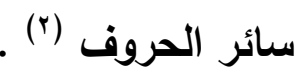

ثانياً:القائلون بلالالة الحرف على معنى فى نفسه: ومراد هؤلاء أن للحرف دلالة على معناه في حال استعماله منفردًا أو في حال انضمامه في التركيب إلى كلمات أخرى .

$$
\begin{aligned}
& \text { (1) شرح المفصل (1) (1) }
\end{aligned}
$$

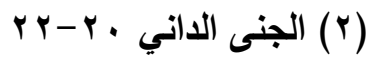


وممن نسب إليه هذا القول بهاء الدين بن النحاس الحلبي (ت 9 (تهـ) فقد

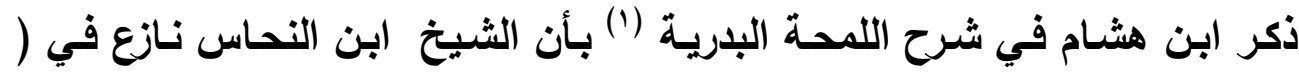
التعليقة) النحويين وزعم أن الحرف دال على معنى في نفسه. كما زعم ابن هشام أن أبا حيان قد تابعه في شرح (التسـيل) ثم علق بقولـه "وهو موضع يحتاج فيه إلى فضل نظر"(؟) وهذه العبارة من ابن هشام تدل على

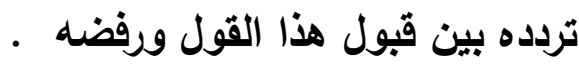
وقد نقل السيوطي عن ابن هشـام ذلك وأردف بنقل عبارة ابـن النحساس كاملة، و منها قوله : "...والحق أن الحرف له معنى في نفسه، لأنا نقول :لا يخلو المخاطب بالحرف من أن يفهم موضوعه لغة أو لا، فلا دليل في عدم فهم المعنى أنه لا معنى له، لأنه لو خوطب بالاسم والفعل وهو لا يفهم موضوعهما لغة كان كذلك، وإن خوطب به من يفهم موضـوعه لغة، فإنها يفهم منـه معنى عمـلا بفهمـه

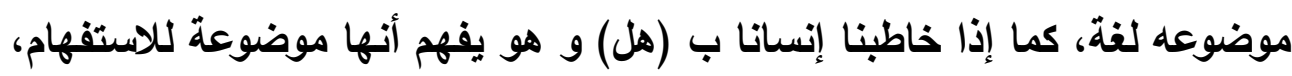
وكذا باقي الحروف، فإذًا عرفنا أن له معنى في نفسه ...و اللغويون كلهم قالوا : " إن( هل) للاستفهام، ولم يقيدوا بحال التركيب دون حال الإفراد . فإن قيل : أي فرق بين معنى الاسم و الفعل و بين معنى الحرف على مـا ذكرث قلنا الفرق بينهما أن كل وإحد من الاسـم و الفعل يفهم منـه في حال الإفراد عين ما يفهم منه عند التركيب بخلاف الحرف، لأن المعنى المفهوم من الحرف في حال التركيب أتثم مما يفهم منه عند الإفراد، هذا كلام ابن النحاس بحروفه (َ) .

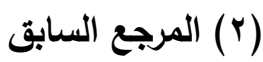

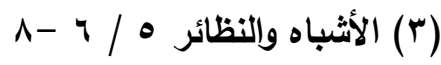


و قد علق السيوطي على زعم ابن هشام موافقة أبي حيان في شرح التسهيل

لابن النحاس بقوله : "ولم أره فيه، فلعله سقط من النسخة التي وقفت علئ عليها" (1) .

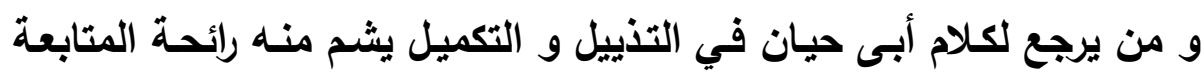

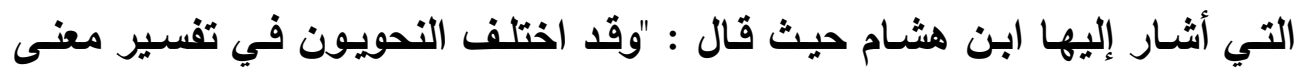

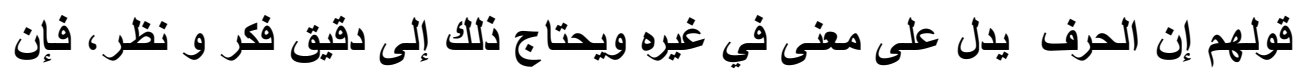

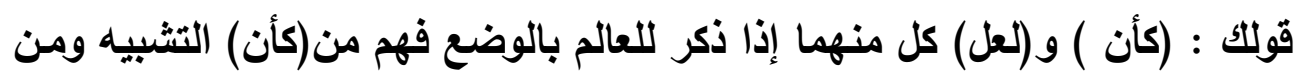

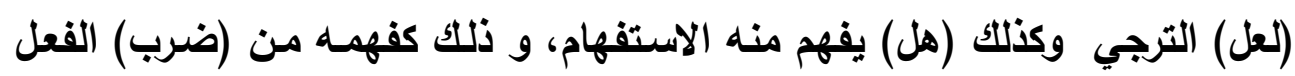

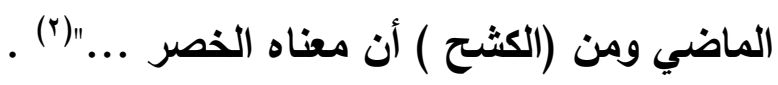

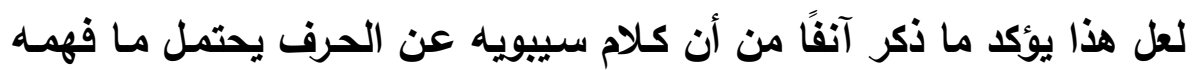
السبرافي كما يحتمل خلافه، وهو دلالته على معنى في نفسه أيضًا .

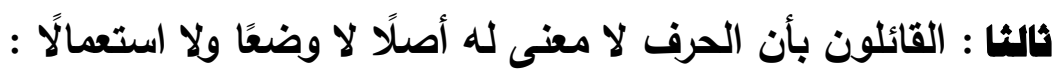

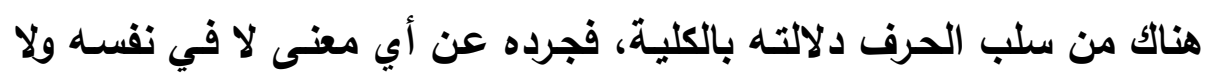
في غيره، نقل ذلك السيوطي في الأثباه والنظائر عن الثريف الجرجاني مخالفًا

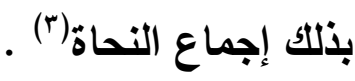
وقد وصف السيوطي هذا القول بأنها أغرب ممن زعم دلالـة الحرف على في

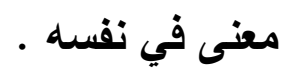
وقد زعم الاكتور عبد الهادي الفضلي في كتابه اللامـات( (1) أن هذا المذهب

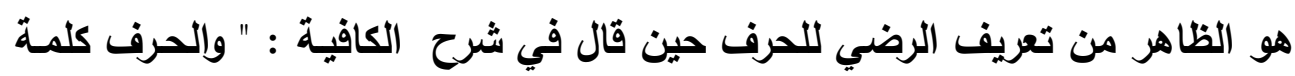

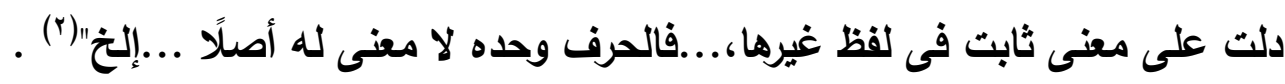

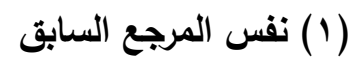
$0 . / 1(r)$

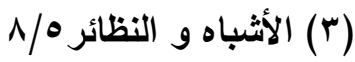




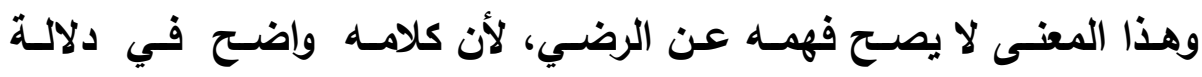

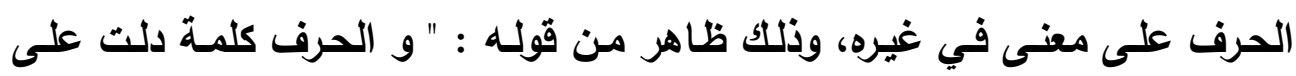

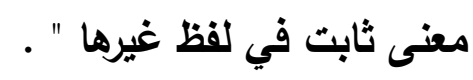
و قوله أيضًا : " فالحرف موجود لمعناه في لفظ غيره "(") . .

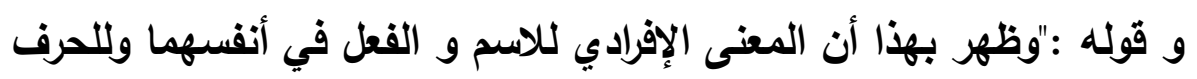

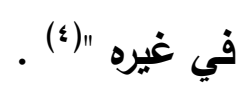

ويالنظر في مذاهب متقدمي النحويين في معنى الحرف و دلالته، يتبين أن

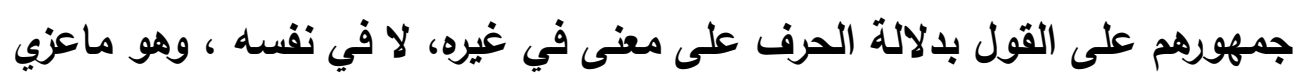
لسييويه، وجزم به السبرافي، وإن كانت عبارة سييويه تحتمل كما أسلفت.

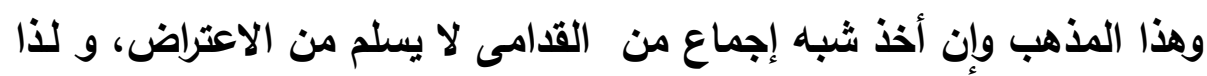

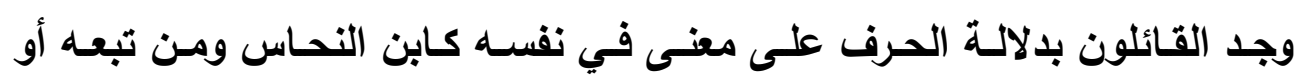

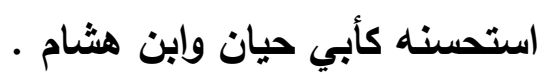

ويؤيد ذلك ما نقله ابن يعيش عن الفارسي من اعتراضه على على من حد الحرف

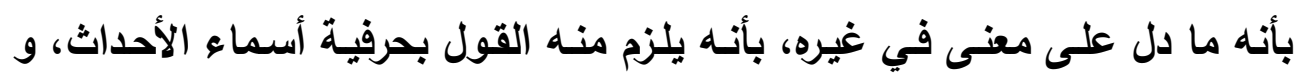

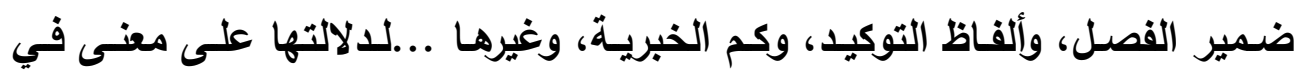
غيرها، كما يلزمه القول بعدم حرفية (ما) في نحو قولهم : إنتك ما وخيرًا، وكذلكك :

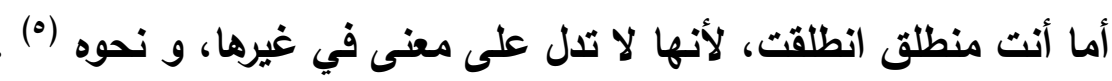

$$
\begin{aligned}
& \text { ט (1) }
\end{aligned}
$$

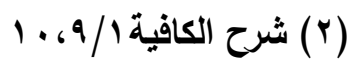

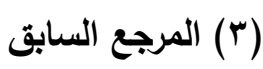

$$
\begin{aligned}
& \text { (؛ ) المرجع السابق المرجع المابي }
\end{aligned}
$$

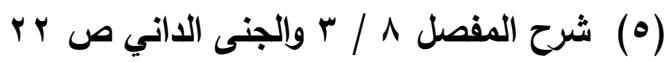


و مما يعترض به على مذهب الجمهور أن هناتك من الأسماء ما معانيها في

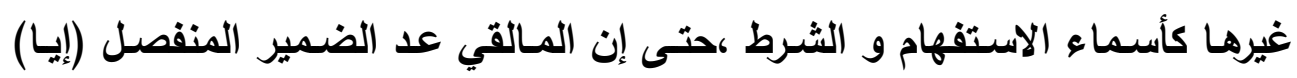

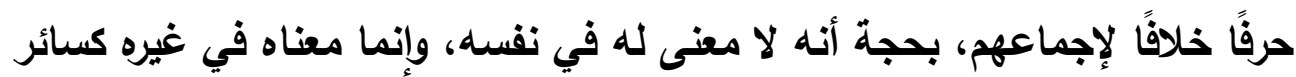

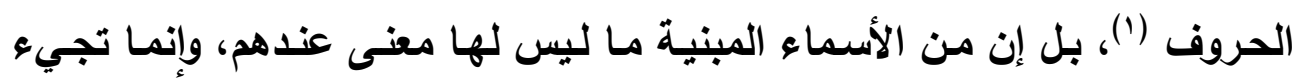

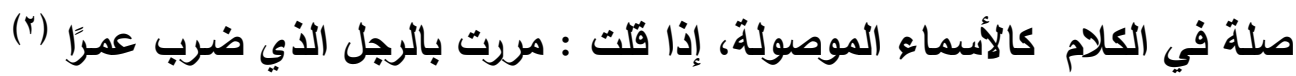

و لثبه تلك الأسماء المبنية بالحرف في بنيته ومعناه وجب معه إتحادهما في (الحكم () (ن) و مثله نيابة بعض حروف المعاني عن الفعل لمجيئها بمعناه ك (إن)و( كأن)

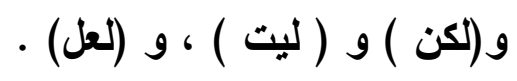

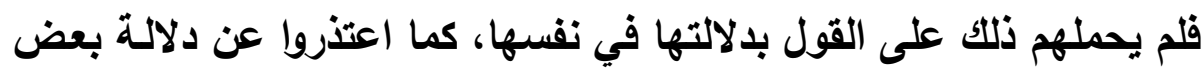

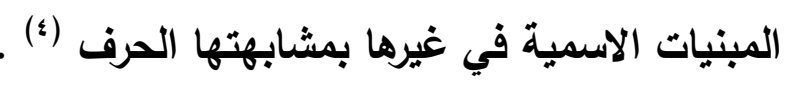

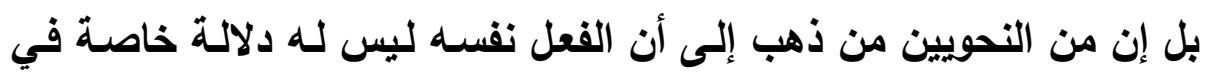

نفسه ،وقريه بذلك من الحرف في دلالته المقيدة (0) .

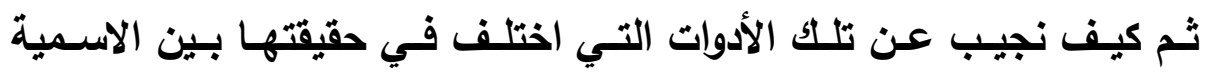
والحرفية ك(أل) و(عن) ،و (الكاف) و (إذ ما) و( أيـم)، و( بلـه )، و وكم الخبريـة) وغيرها كثير (') والجرفة (ان)

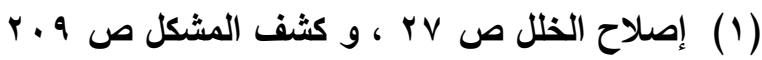

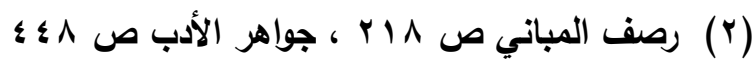

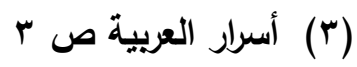

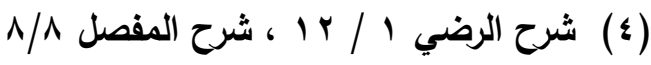

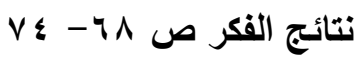


ويين الفعلية والحرفية ك(عدا)، و(حاشا)، و (خلا)، و(عسى)، و(ليس) وغيرها

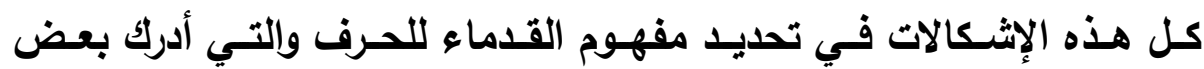

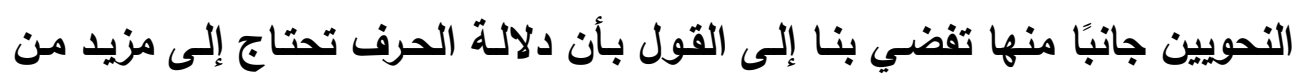

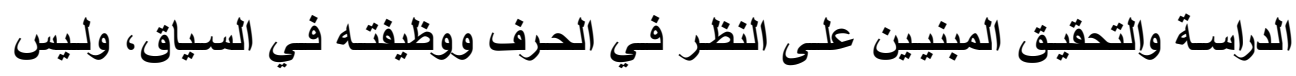
مجردًا من التركيب . ولذا فإن القول بدلالة الاسم والفعل على معنى فيهما وتجريد الحرف من ذلتك فيهه نظر من حيث إن دلالتهما في نفسيهما لا يحدث من ورائها فائدة في حسال

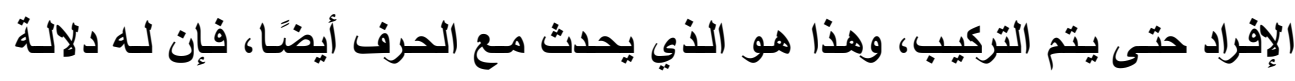

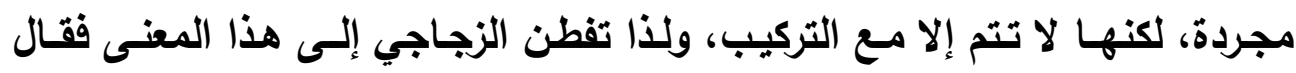

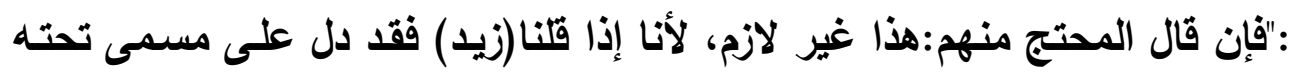

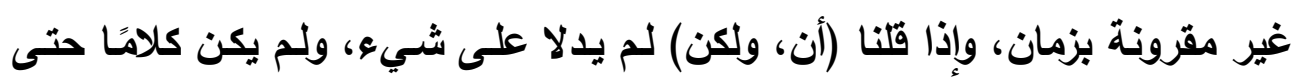
يقرن بجملة.

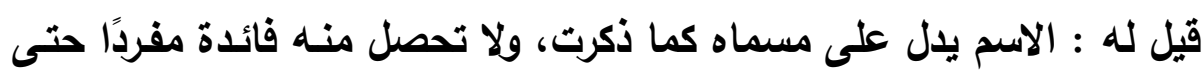

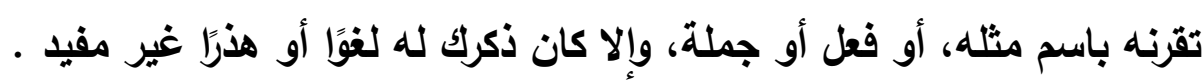

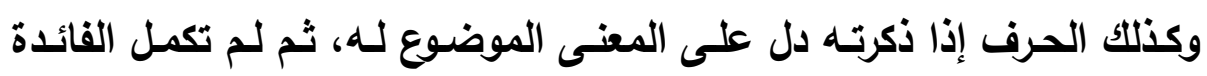

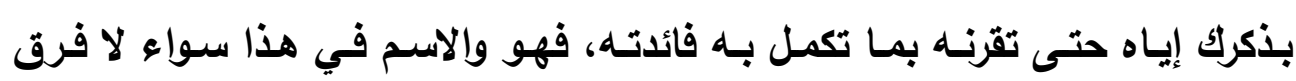

بينهما (َ) بلانكر إن)

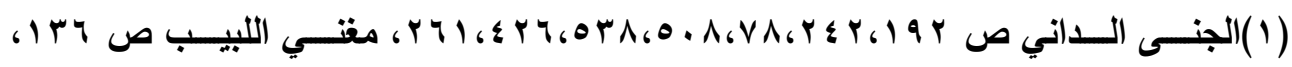

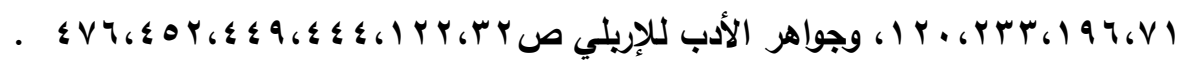

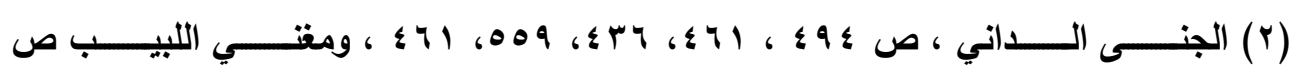

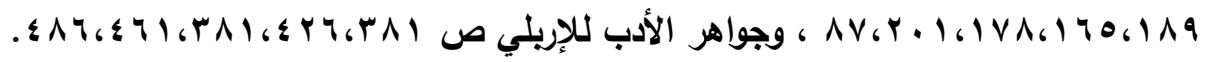

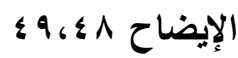




\section{الامطاب الثاني \\ آراء الدارسين المددثين}

اختلفت آراء النحاة المعاصرين حول دلالة الحرف، فمنهم من ذهب مذهب

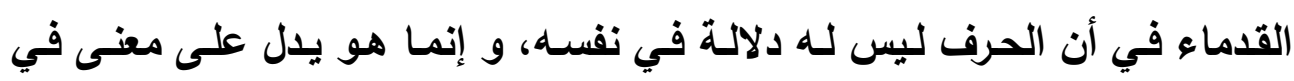

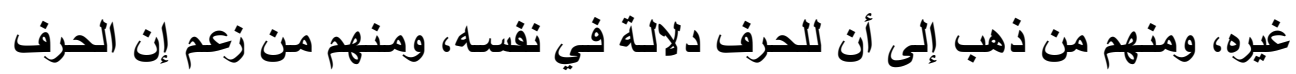

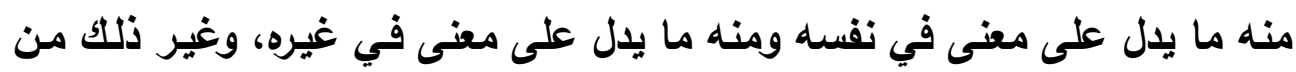
الآراء التي ستكثف عنها هذه الدراسة على على النحو التالي :

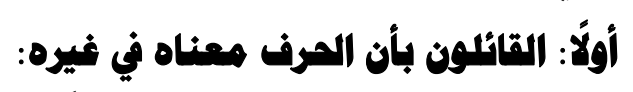

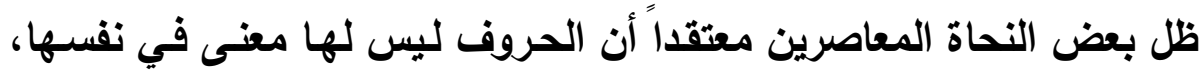

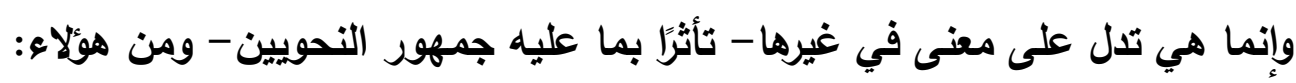

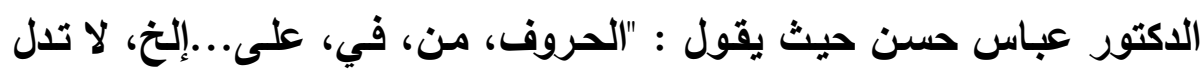

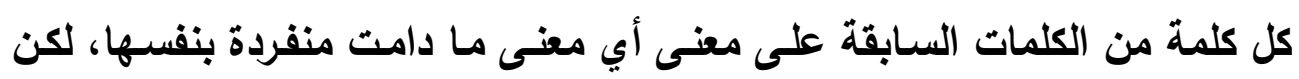

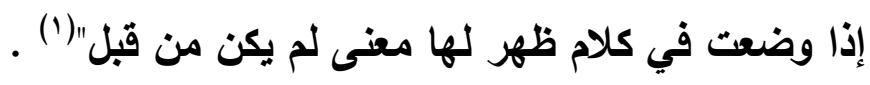

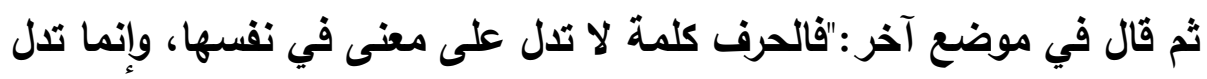

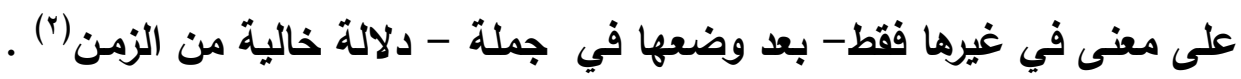

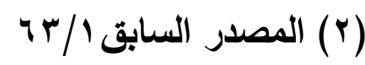


وكذللك الثيخ مصطقى الغلاييني، إذ يقول: "الحرف مـا دل على معنى في

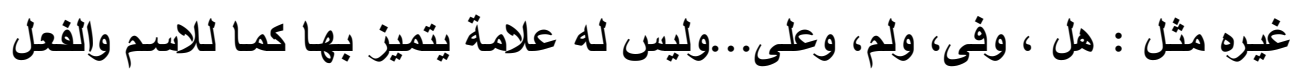

وذكر مثل ذلك كل من الدكتور محمد عيد(ץ)، وعلى رضـا(")، ومحمد السبد

الهاشمي(؛)

وممن قال بذلكك أيضـاً الدكتور مهـي المخزومي حيث يقول :" إن الأدوات

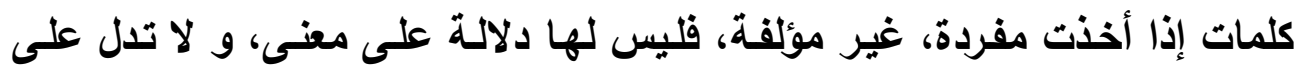

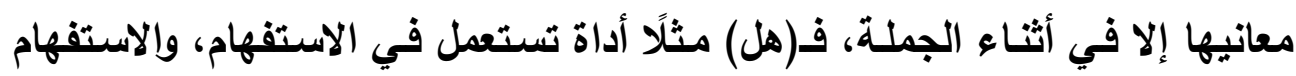

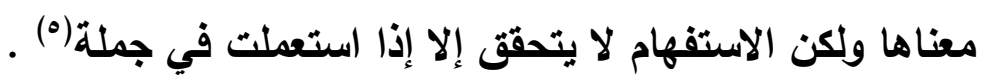
أما الأستاذان على الجارم ومصطفى أمين فيقولان:"الحرف كل لفظ لاعظ لا يظهر

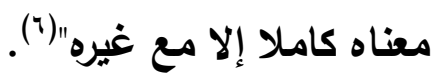
وهو إقرار منهمـا بأن الحرف يحمـل دلالـة خاصـة في نفسـه منفردًا، ولكن فئن المعنى الكامل له يظهر في غيره وذلك في ثنايا الجملة . ثانياً:القاثلون بأن المرف له له معنى في نفسيه :

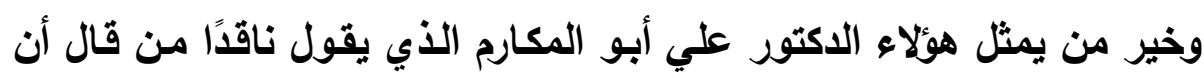

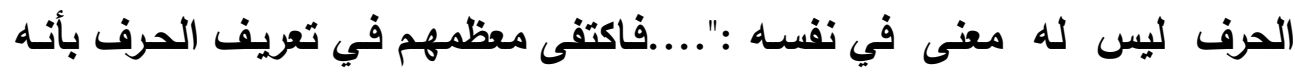

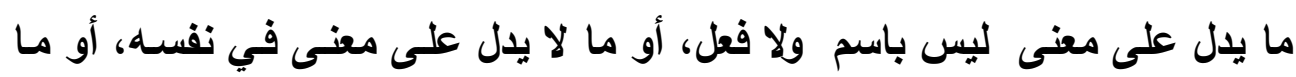

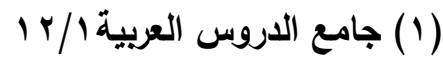

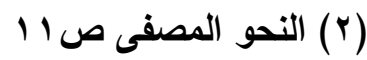

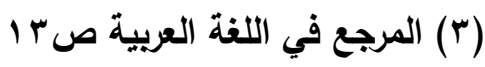

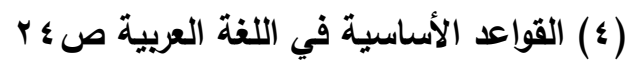

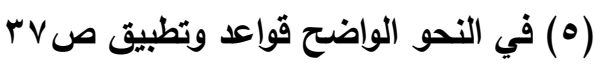

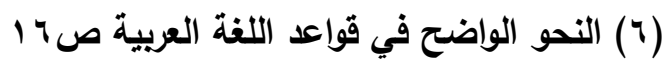


دل على معنى في غيره، دون ملاحظة أن الحروف في اللغة العربية لها دلالتها

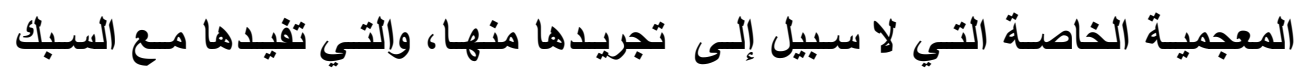
التركيبي وقبله معًا، بحيث يعد تعريفها بأنها (لا تدل على معنى في نفسها) بين

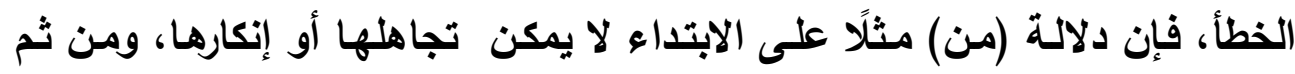

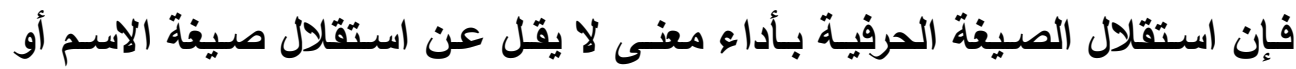
صيغة الفعل بأداء ما يقصد بها من معنى. فهذه الوحدات الثلاث خارج التركيب اللغوي - وهى الاسم والفعل والحرف - تتشـابه من حيث دلالتها على معنى خاص

جزئي يتغير بالتركيب وتتحدد به علاقاته (1) وقد انتقد أيضًا الدكتور إبراهيم أنيس النحويين القدماء في تجريدهم الحروف من معانيها في نفسها فقال:"أما علاجهم للحروف فأمره عجب، وذلك لأنهم يكادون يجردونها من المعاني وينسبون معناهـا لغيرها من الأسـماء والأفعال، فلمـا عثروا على شـوا هد...فيه (على بمعنى فوق)...وفيـه (عن بمعنى ناحيـة) قالوا إن مـن الحروف ما يستعمل استعمال الأسماء في بعض الأحيان"(ז) . ويمكـن أن يعــ رأي الأسـتاذين عـى الجـارم ومصـفى أمسين السـابق ذكـره متفقاً مع هذه الروئية للحرف.

\section{ثالثا:القاتلمون باختلاف المروف وتفاوتها في الدلالة:}

حيث يقسم بعضهم الحروف إلى حروف إيجادية وحروف إخطارية (r) أما الحروف الإيجادية مثل حروف الجر والتداء والتمني والترجي الموضوعة لإيجاد النسبة أو العلاقة بين الألفاظ حين استعمالها في الجملة، فمثنًا في قولنسا :

$$
\begin{aligned}
& \text { (1) تقويم الفكر النحوي ص ا A. }
\end{aligned}
$$

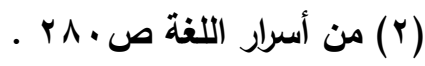

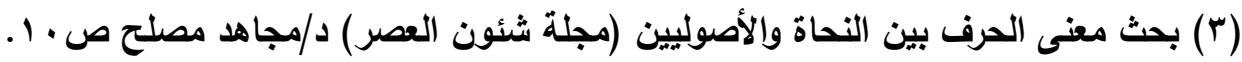




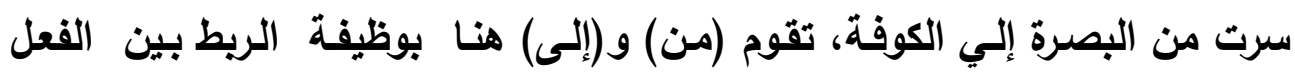

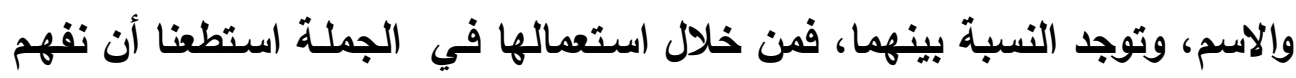

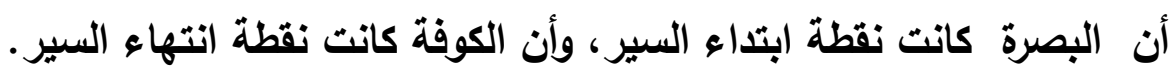

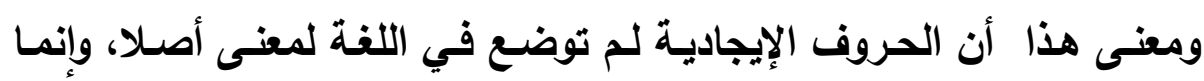
كانت تستعمل كأدوات ريط بين الألفاظ فقط . الإنجاله وهو مـا يعنيه من سموا حروف المعاني ب (حروف النسبة) (1) لأنها تقوم بدور الريط بين معاني الجملة. أما الحروف الإخطارية (ץ) فتلك التي تحكي عن معنى مخطر ومحضر في

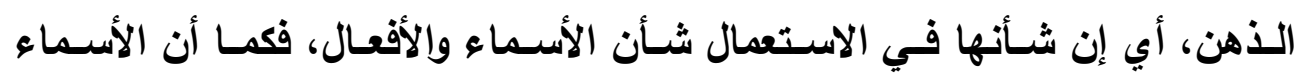

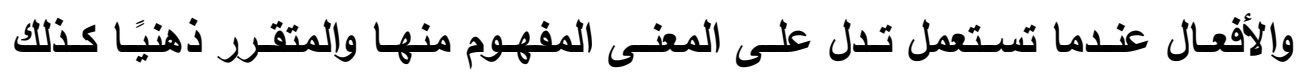
الحروف الإخطارية.

بينما يرى الدكتور عبد الهادي الفضلـي أنها من خـلال استقراء استعمالات

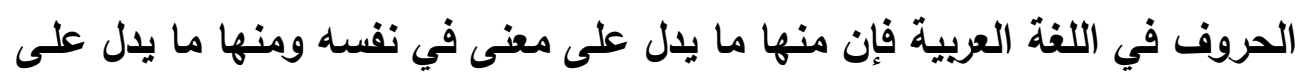

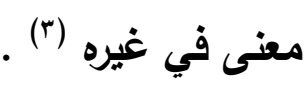
أما الاكتور محمد خير الحلواني فيفهم من كلامسه عن الحرف أن منـه مـا لا

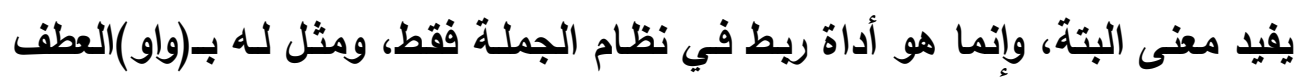
في قولك : جاء فلان وفلان، و(من)الجارة في قولك :خرج سعيد من البيت، ومنـه

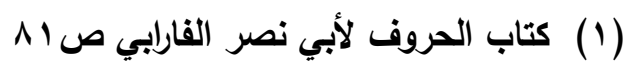

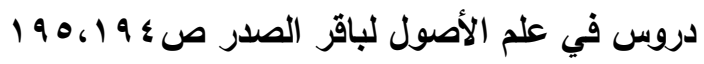

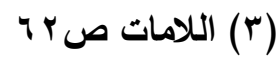


مـا يؤدي معاني خاصـة كالاستفهام والثرط والتمنسي وإلترجي وإلنفي، غير أنها لا تؤدي معناها إلا في التركيب بخلاف الاسم والفعل (') . رابعاً: رأي الدكتور تهام حسان:

وقد سـمى الحرف أداة، يقـول:"الأداة مبنسى تقسيمي يـؤدي معنس التعليق،

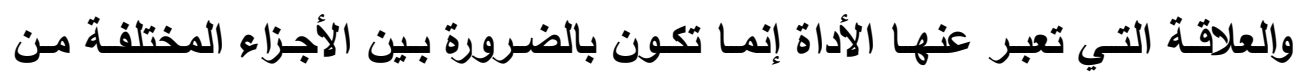

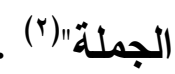

ولقد توسـع تمام حسان في مفهوم الأدوات وقال : إن الأدوات منها الأصلية

ومنها المحولة .

أما الأصلية وهى الحروف ذات المعاني كحروف الجر والنسخ والعطف...الخ، والمحولية كالظروف التي تتصدر جملة الثرط أو الاستفهام وكالأسماء والنكرات التي تستعمل لإبهامها استعمال الحرف، وكالنواسخ الآتية على صور الأفعال ولكنها

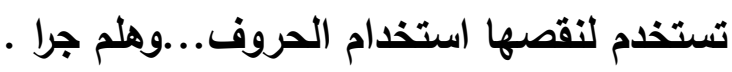
ويشتمل قسم الأدوات عند تمـام على الأدوات وحروف المعاني، وكلها يـلـال

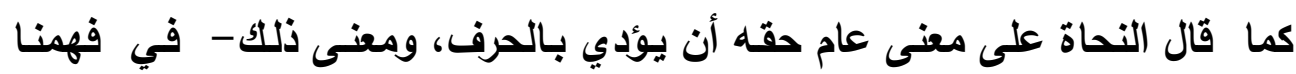

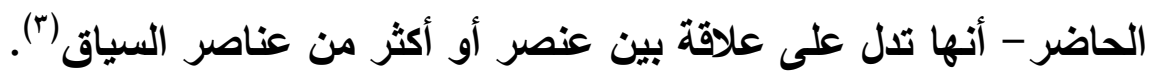
والتعليق بالأداة أثهر أنواع التعليق في اللفة العربية الفصحى، فإنهر إذا استثنينا

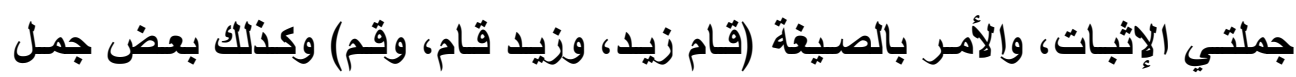

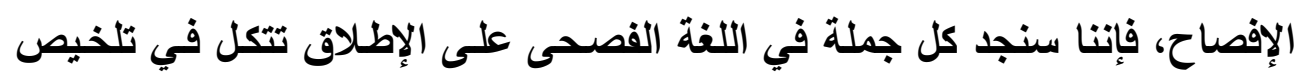

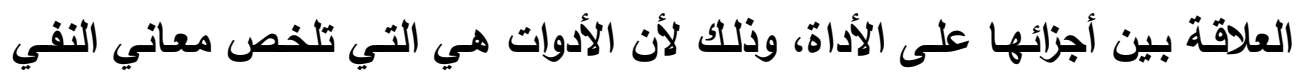

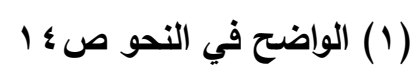

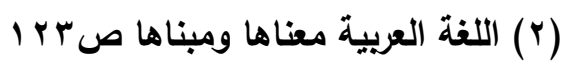

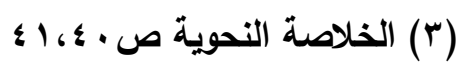


والتأكيد والاستفهام والأمسر بـاللام والعرض والتحضيض والتمنـي والترجي و النـداء والشرط الامتناعي والثرط الإمكاني والقسم والندبة والاستغاثة والتعجب، كل ذلك بالإضـافة إلـى مـا لـلأداة مـن وظليفة الـربط بـين الأدوات المفردة في داخل الجملـة كالذي نجده في حروف الجر والعطف والاسـتثناء والمعيـة وواو الحسال، أو مـن وظيفة أداء معنى صرفي كالذي نراه في أداة التعريف.

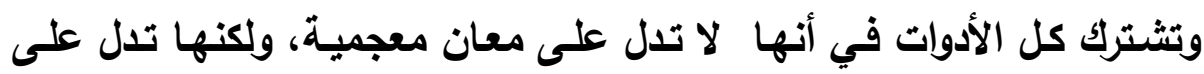
معنى وظيفي عام، وهو التعليق، ثم تختص كل طائفة منها تعت هذا العنوان العام بوظيفة خاصة،كالنفي والتأكيل...وهلم جرا، حيث تكون الأداة هي العنصر الرابط بين أجزاء الجملـة كلها،حتى يمكن لـلأداة عند حذف الجملـة أن تؤدي المعنى كـاملاً، كالذي نـراه في عبـارات مثل،لم، وعم، ومتى، وأيـن، وريمـا، وإن، ولعل، وليت،

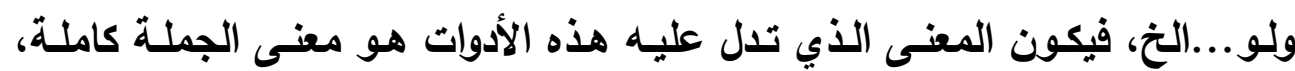
وتحدده القرينة بالطبع (1) وقد اجتهد تمام حسان في إيجاد ما يميز الأدوات عن بقية أقسام الكلام من بن الناحية الدلالية، فنكر منها : ا - من حيث التعليق : المعاني التي تؤديها الأدوات جميعا هـي من نـوع التعبير عن علاقات في السياق، وواضـح أن التعبير عن العلاقة معنى وظيفي لا

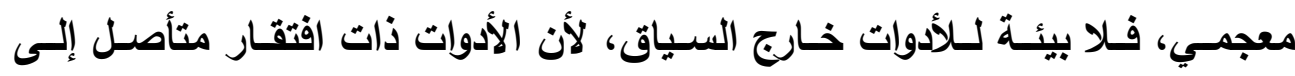
الضمائم، أو إلى افتقار متأصل إلى السياق . و عليه، فإن الأدوات من أهم وسـائل التعليث في اللغة، ولهـذا أصر التحاة على تعيين متعلق خاص للجار والمجرور في الإعراب، بل إنهم لمـا رأوا الظروف تسلك مسالك الأدوات أحيانا، قالوا بتعليق الظرف أيضا . 
r - من حيث المعنى الجملي : حين تحمل الأداة تلخيص أسلوب الجملة، قد

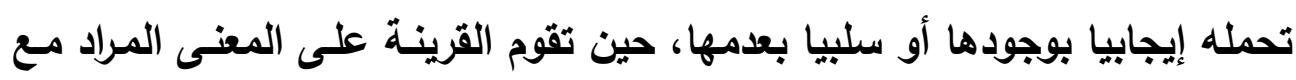

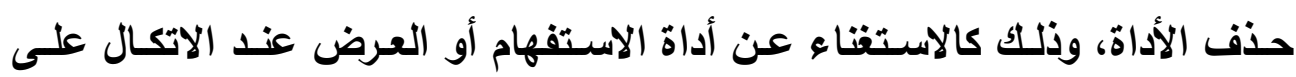

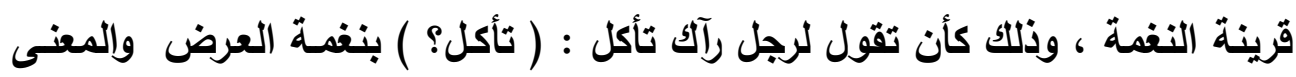

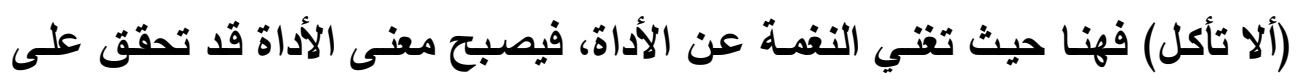

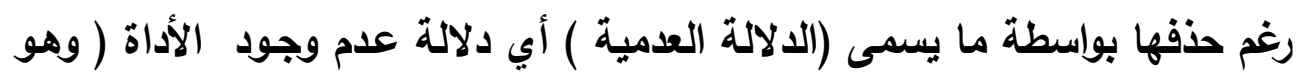

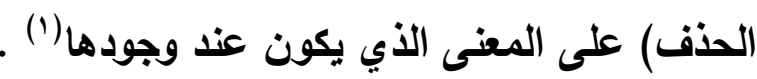

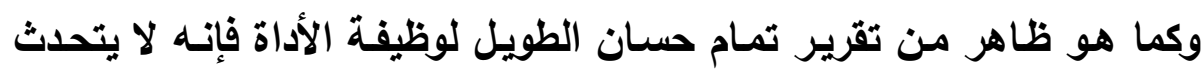

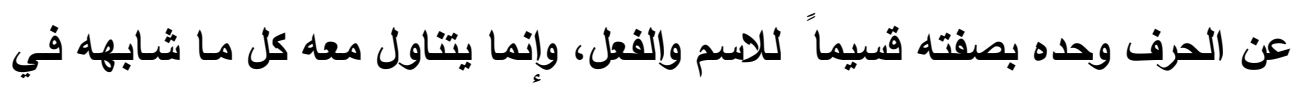
وظيفته من أسماء وأفعال . وخلاصة القول بعد ذكر تلكت الأقوال المتباينة لأولئكت النحاة المتقدمين منهم

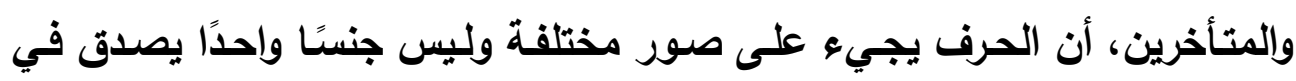

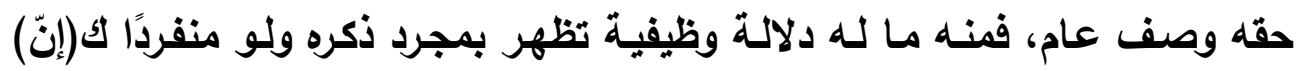

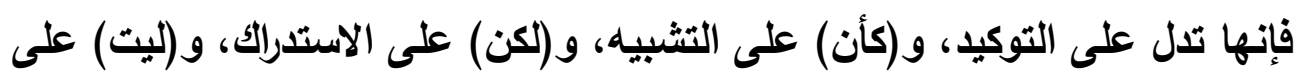

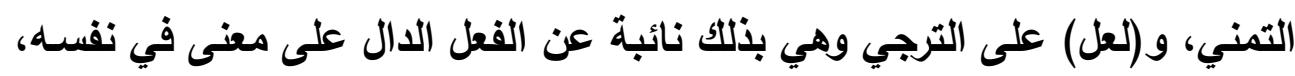

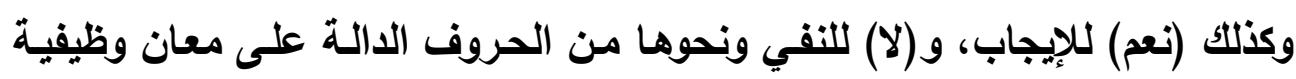

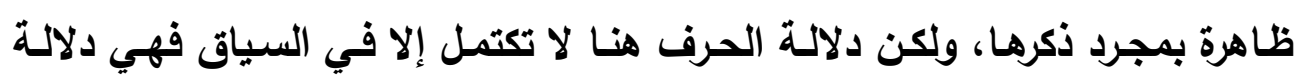

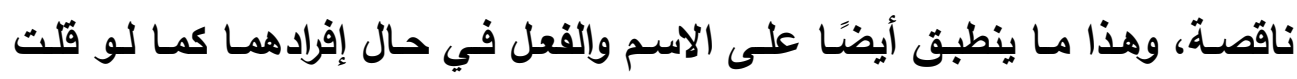

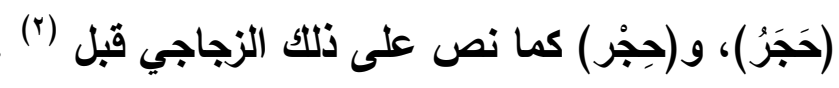

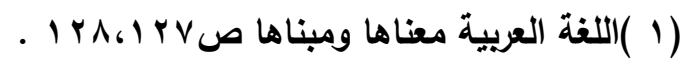

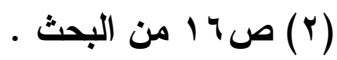


ومن الحروف ما له دلالة وظيفية أيضًا لكنها لا تظهر إلا في حال التركيب

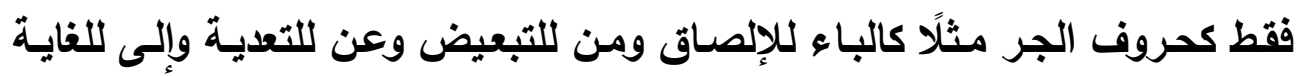

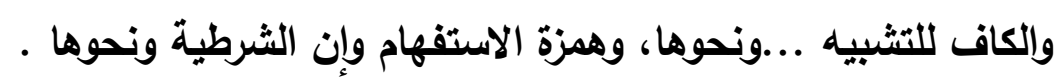

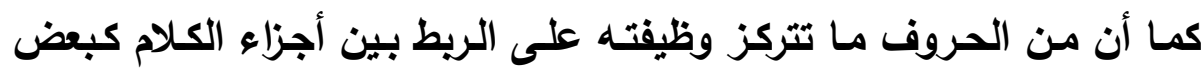

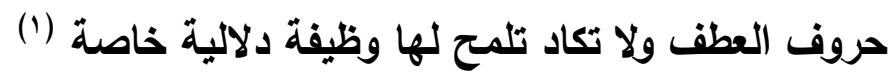

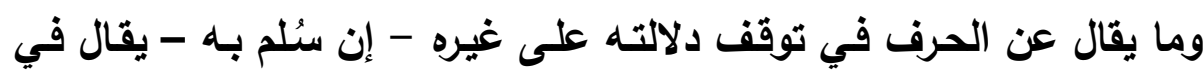

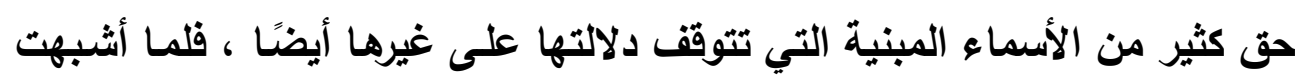

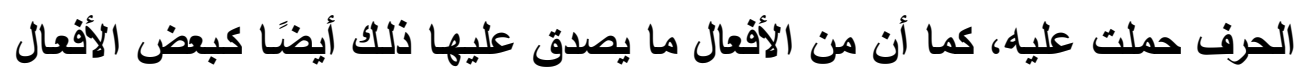

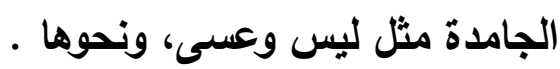

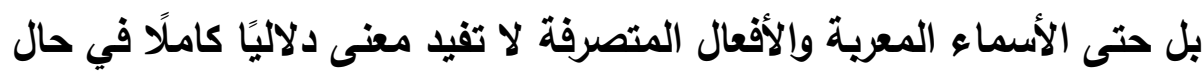
إفرادها كما تفيده في حال تركيبها. وعليه فإن إطلاق الحكم على الحرف بتجرده عن معناه في نفسـه، ونفي ذلكاد عن الاسم والفعل بإطلاق ليس حكمًا صائبًا في نظري، إذ الأمر يحتاج إلى تفصيل

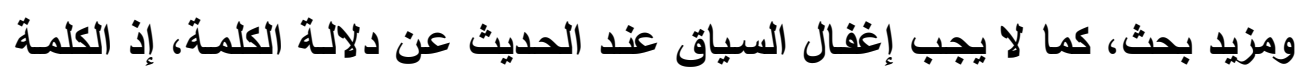
خارجه لا تحمل قيمة دلالية وهذا ما تفطن لله بعض علاعل علداء الأصول والبلاغيين.

(1) ينظر في ذلك : الاستدلال في معاني الحروف .دراسة في اللغة والأصول .ص r Y-Y . . 


\section{خاتمة البحث}

تناولت هذه الدراسـة موضوع (موضع حروف المعاني ودلالتها في الخطاب

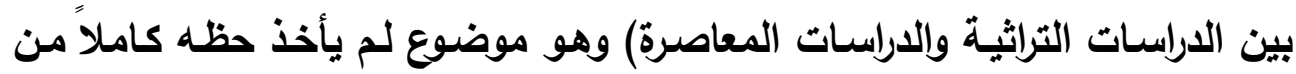
الدراسات النحوية .

فلقد حاول جمهور النحاة رسم صورة لكل قسم من أقسام الكلام تميزه عن

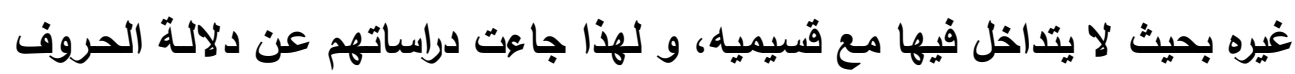
مقتضبة و غير معنية بالسياق.

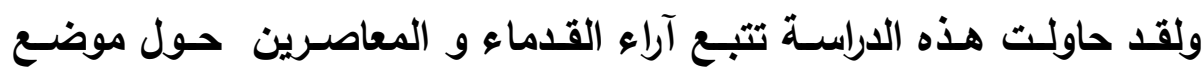
الحرف ودلالته، فوجدت أن جمهور القدماء قد ذهبوا إلى التقسيم الثثلاثي للكلام، لا لا

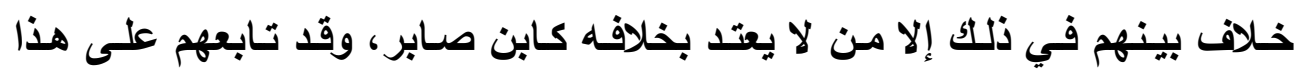

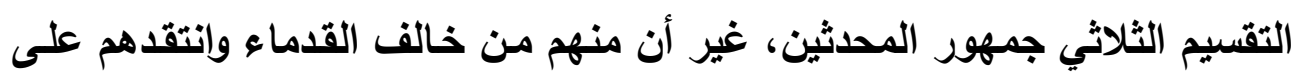
ذلك، واجتهدوا بوضع أقسام جديدة للكلام .

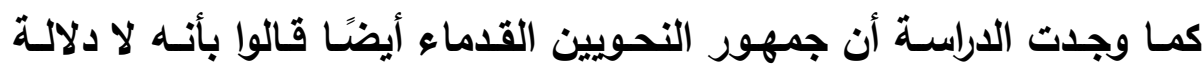

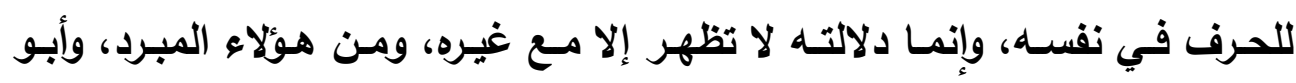

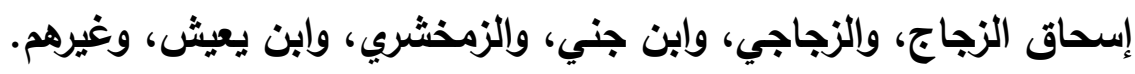

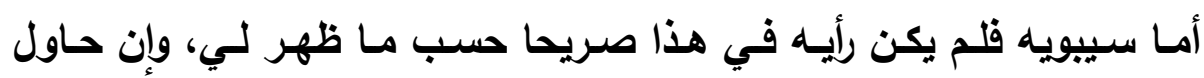
السيرافي تأكيده. وظهر من النحاة من قال بأن الحرف يدل على مغنى في نفسه، كابن النحاس الحلبي وأبى حيان الأندلسي. كما برز رأى شاذ يقول إن الحروف لا معنى لها أصلا لا وضعا ولا استعمالا

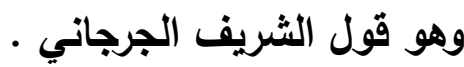


أمـا آراء المحدثين في دلالـة الحروف فكثفت الدراسـة عن تأثر معظمهم بالقدماء، وقالوا بلالة الحرف على معنى في غيره،أمثال عباس حسن ومحمد عيد

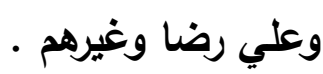
وقليل منهم من صرح بأن الحرف لـه معنى في نفسـه كالاكتور علي أبو المكارم والدكتور إبراهيم أنيس.

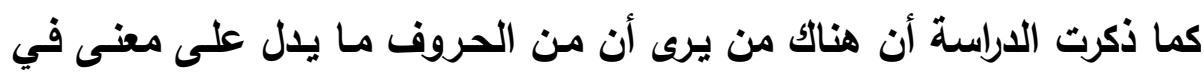
نفسه و منها ما يال على معنى في غيره ،ومنها ما وظيفته الريط فقط . وكان للاكتور تمام حسان رؤى خاصة حول الحروف وماهيتها ودلالتها.

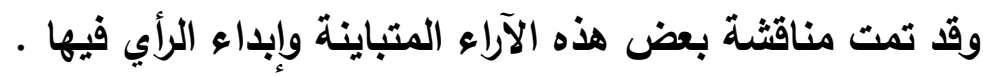

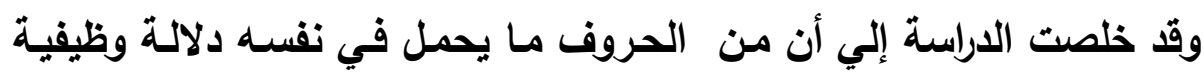
خاصة عند الوضع،لكنها دلالة ناقصة لا تتجلى إلا مع التركيب و السياق.

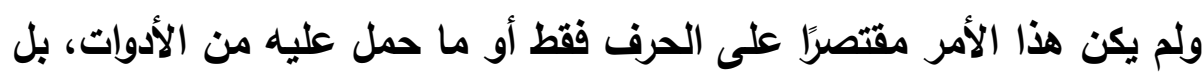

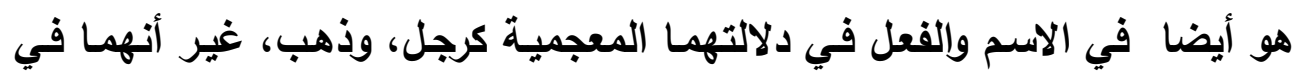

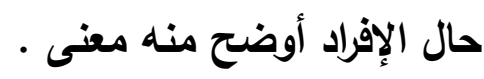

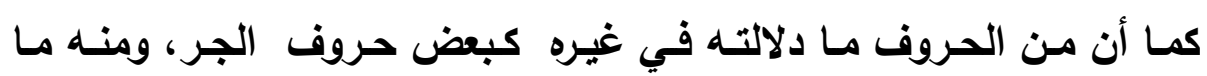

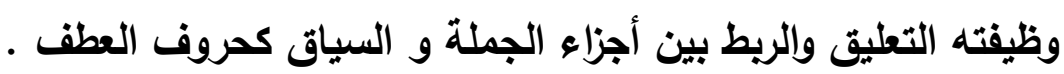

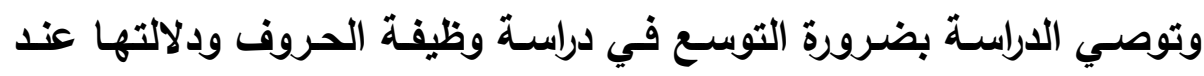

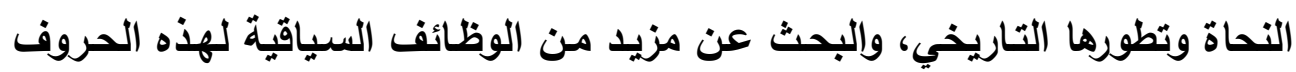

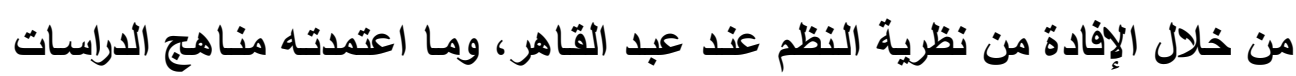
اللسانية الحديثة . 


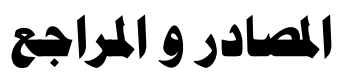

ا - الإتقان في علوم القرآن للسيوطي- الطبعة الثالثة- . V I ا هـ. r- أثز الموروث النحوي في مقترحات محاولات التيسير النحوي المعاصر،

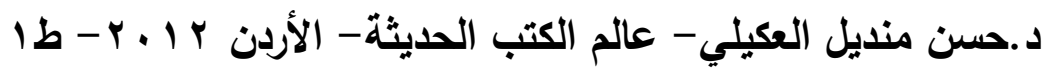
ب- الأدوات النحويـة وتعدد معانيها الوظيفيـة، د. أبو السـود الثـاذلي - دار المعرفة الجامعية- الإسكندرية- مصر - الطبعة الأولى 9 ه ام.

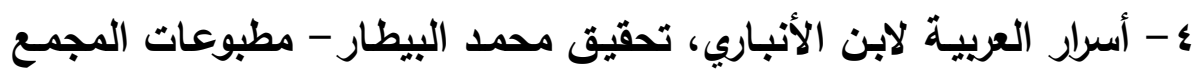

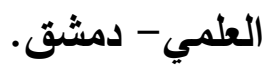
ه- الأشـباه والنظـائر للسـيوطي، تحقيـق عبد العـال سـالم مكرم - مؤسسـة

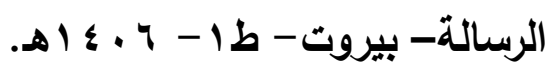

צ- إصـلاح الخلل لابـن السـيد البطليوسـي، تحقيـق حمـزة النشـرتي- دار

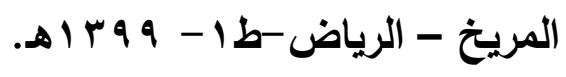

- V إصــلاح النحــو، ليعقـوب عبـــ التبـي - مخطــوط بمجمــع اللغــة

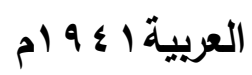

1- الأصول في النحو لابن السراج، تحقيق د.عبد الحسين الفتلي- مؤسسـة

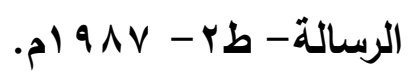

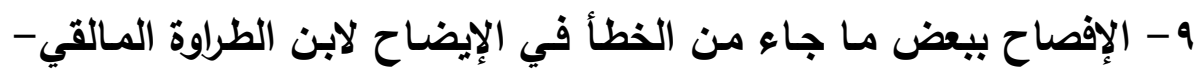

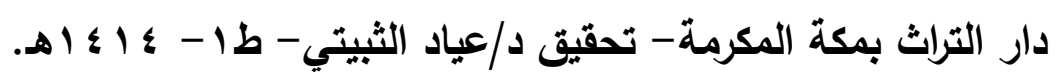

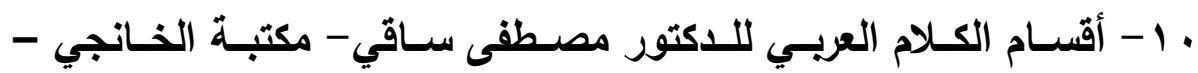

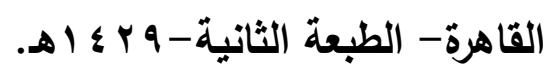

1 ا - أوضح المسالك لابن هشام، تحقيق محمد محيي الدين عبد الحميد-

$$
\text { المركز العربي للثقافة والعلوم- بيروت- طج- } 7 \text { - } 9 \text { ام. }
$$


r ا - الإيضاح العضدي للفارسي، تحقيق حسن شاذلي فرهود - دار التأليف-

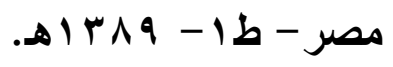

ب ا - الإيضاح في علل النحو للزجاجي، تحقيق د.مـازن المبارك-دار نفائس

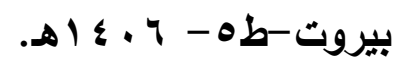

ع ا-البسيط في شـرح الجمل لابـن أبسي الريبع، ت: د. عيـاد الثبيتي - دار

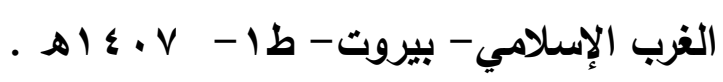

ه - بغية الإيضاح للصعيدي - مكتبة الآداب بالجماميز - القاهرة.

1 ا 1 - البلاغة تطور وتاريخ - شوقي ضيف- دار المعارف- القاهرة- طمل.

$$
\text { IV }
$$

1 ا - التذييل والتكميل لأبسي حيان الأندلسي- - تحقيق د د/حسن هنداوي -

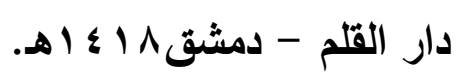

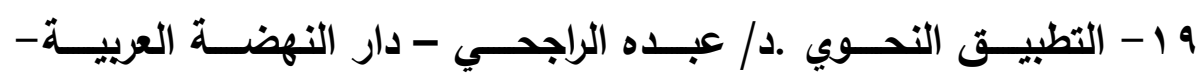

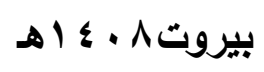

• r - تقويم الفكر النحوي. د/علي أبو المكارم- دار الثقافة - بيروت. ا ب - التهذيب الوسيط في التحو للصنعاني، تحقيق فخر صالح سليمان - دار

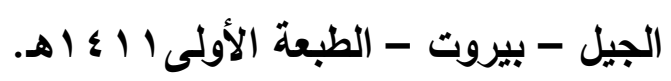

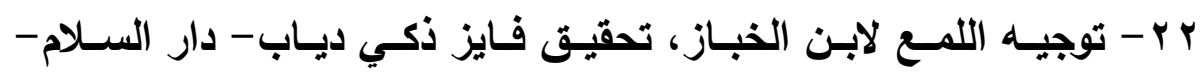

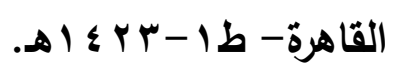

rr - توضيح المقاصد للمرادي - تحقيق د/عبد الرحمن علي سليمان - دار

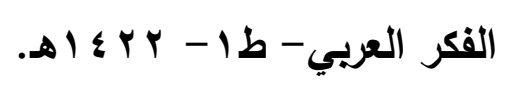

ع ب-جامع الاروس العربية لمصطفى الغلاييني - المكتبة العصرية-بيروت-

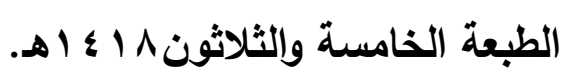


هץ - الجمـل للزجـاجي. تحقيـق علـى توفيـق الحمـــ- مؤسســة الرسـالة-

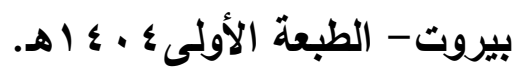

צr - الجنى الداني في حروف المعاني تحقيق فخر الدين قباوة- دار الكتب

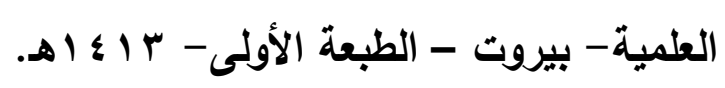

PV - جواهر الأدب في معرفة كلام العرب للإريلي- تحقيق إميل يعقوب- دار الهي

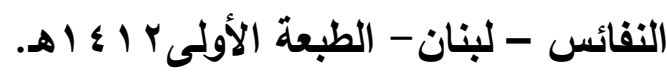

^r - حاشية الصبان على شرح الأثموني على ألفية ابن مالكـ- دار إحياء

$$
\text { الكتب العربية- عيسى البابي الحلبي وشركاه(د.ت ه). }
$$

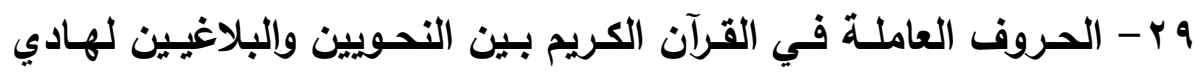

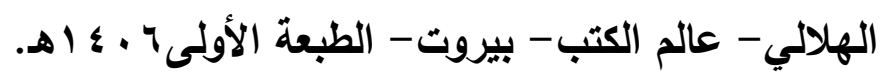

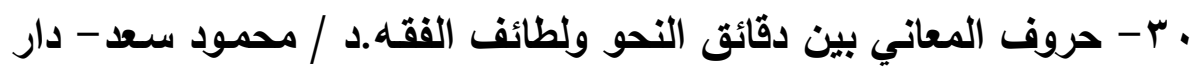

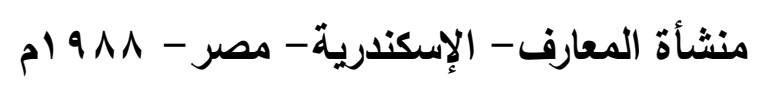

اب - حروف المعاني بين المناطقة والنحاة، فاطمة الحمياني- منشورات كلية

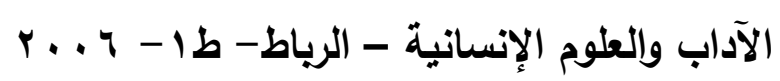

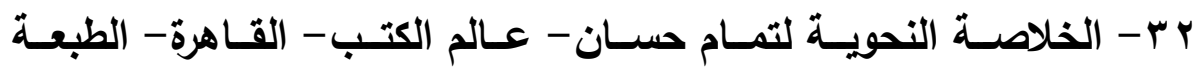

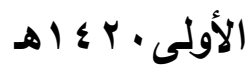

بr - دراسـات فـي الأدوات النحويـة د/مصطفى النحساس - الربيعـان للنشـر

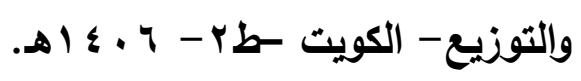

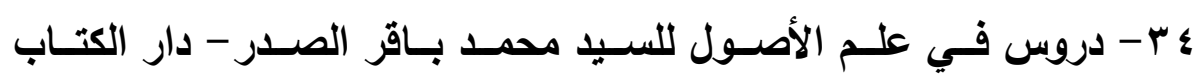

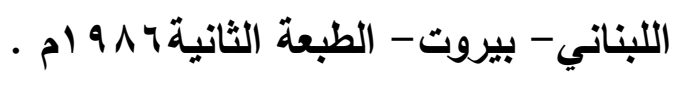

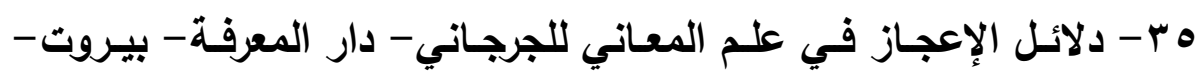


צץ - رصف المبـاني للمـالقي .تحقيق أحمد الخـراط- دار القـم- دمشـق -

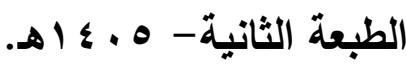
- سر الصناعة لابن جني- تحقيق د/حسن هنداوي - دار القلم - دمشث هـ ^r - شرح ألفيـة ابن مالك لابن النـاظم- تحقيق د/عبد الحميد السيد- دار

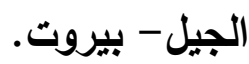
q ب - شرح التسهيل لابن مالك. تحقيق د/عبد الرحمن السيد، ود/محمد بدوي

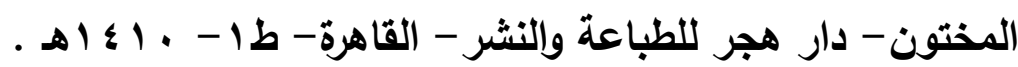
• ع - شرح التصريح على التوضيح - خالا الأزهري - دار الفكر. اء - شرح الجمل لابن بابشـاذ، تحقيق حسين علي السعدي.رسـالة دكتوراه

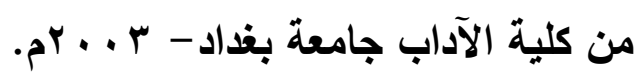

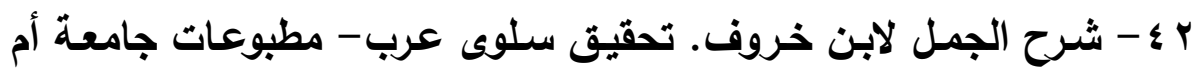

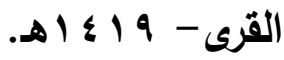

rـ - شرح جمل الزجاجي لابن عصفور - تحقيق صاحب أبو جناح .

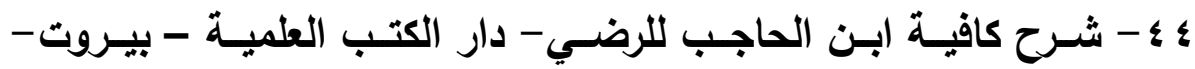

ه) $1 \leqslant$

ه - شرح كتاب سيبويه للسيرافي - تحقيق رمضان عبد التواب ومحمد هاشم عبد الايم ومحمود فهمي حجازي - دار الهيئة المصرية للكتاب. \ء - شرح اللمحة البدرية لابن هثام - تحقيق صلاح رواي - الطبعة الثانية. \& V - شرح المفصل لابن يعيش- عالم الكتب- بيروت

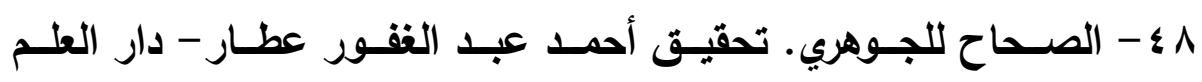
للملايين - بيروت - الطبعة الثالثة. 
9 - العلامة الإعرابية في الجملة بين القديم والحديث للاكتور محمد حماسـة عبد اللطيف/دار غريب القاهزة.

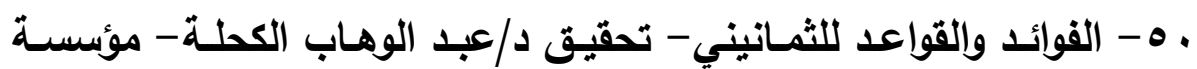

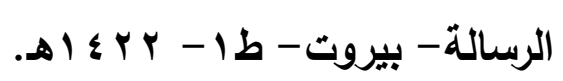

اهـ - في إصلاح النحو العربي.دراسة نقدية، عبد الوارث مبروك سعيد - دار

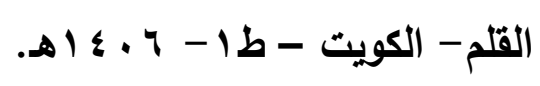

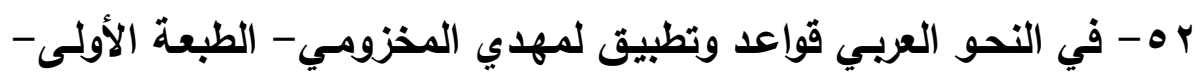

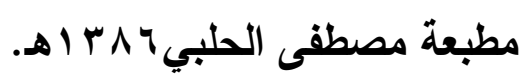

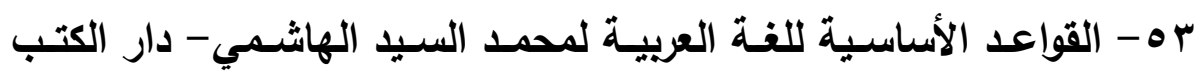

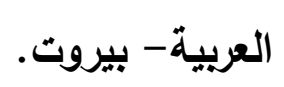

؛ ه - كتـاب الحـروف لأبسى نصـر الفـارابي - تحقيـق محسـن مهـدي - دار

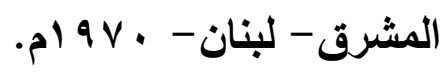

هـ - كتاب سيبويه- تحقيق عبد السلام هارون-عالم الكتب-الطبعة الثالثة. 1ه - كثف المثكل في النحو للحيدرة- تحقيق د/هادي عطية مطر - مطبعة

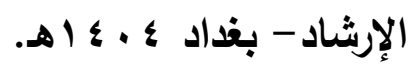
- OV

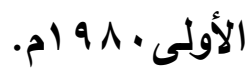
1هـ - اللباب في علل البناء والإعراب للعكبري - تحقيق غازي طليمات - دار

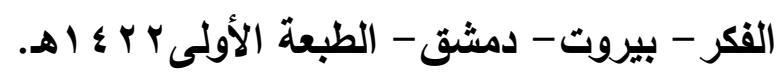

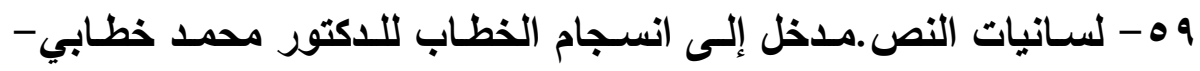

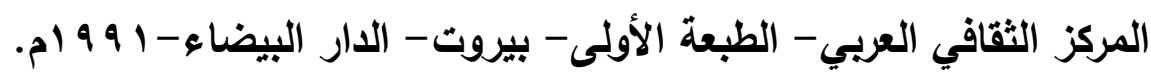

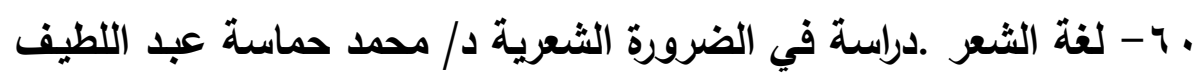

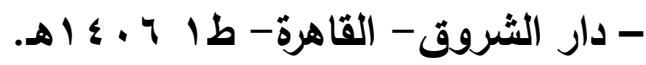


آ- اللغة العربية معناها ومبناها للاكتور تمام حسان - دار الثثافة- الدار البيضاء.

با - اللمع في العربيـة لابن جنـي - تحقيق حامـ المؤمن - عالم الكتب-

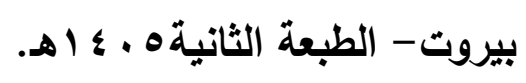

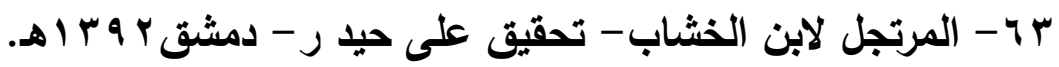
؛ 4 - المرجع في اللغة العربية .علي رضا - دار الفكر - الطبعة الثانية.

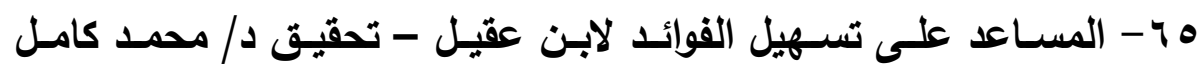

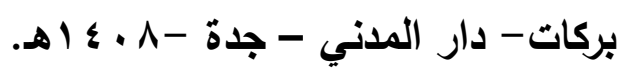

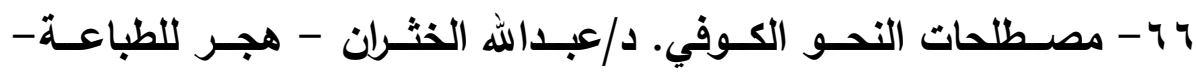
القاهزة ال إ أهـ

Vآ - المصطلح النحوي .عوض القوزي- الناشر عمـادة شئون المكتبات-

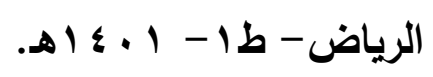

1 - المصطلح النحسوي وتفكير النحساة العرب .توفيـق قريـرة- نشـر كليـة

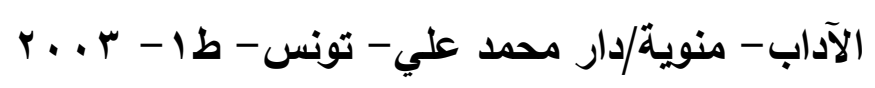

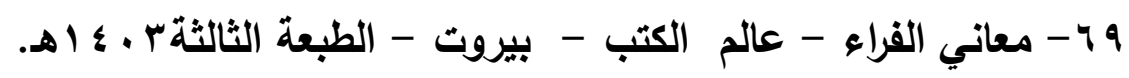

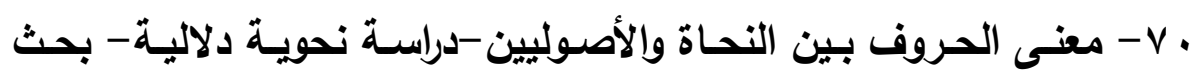

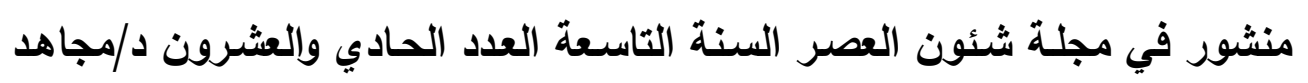
منصور مصلح.

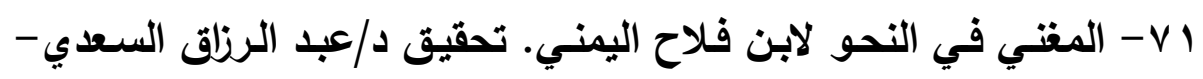

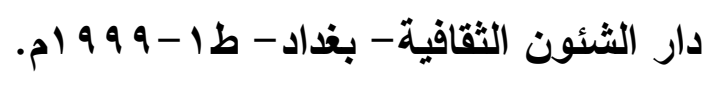

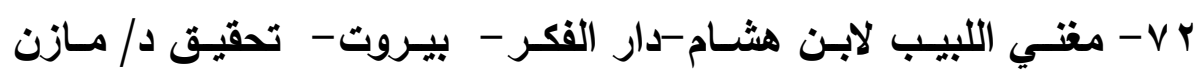

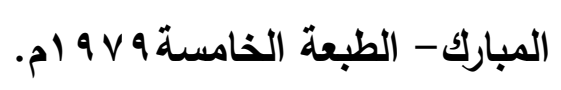




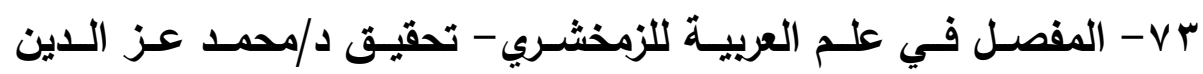

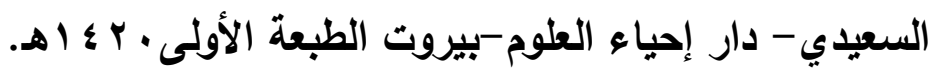

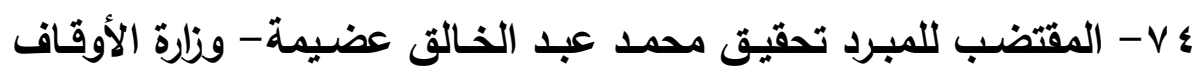

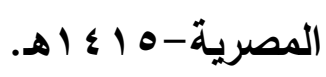
ه - الملخص في ضبط قوانين العربيـة لابن أبي الربيع - تحقيق د.على

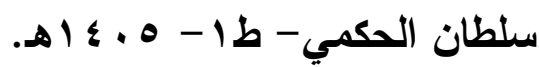
7V - من أسرار اللغة- د/إبراهيم أنيس- مكتبة الأنجلو المصرية.

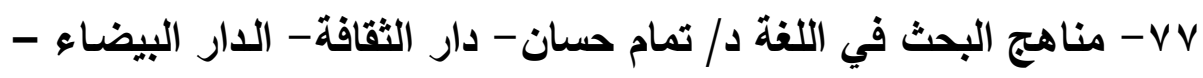
. $1 \varepsilon .7$

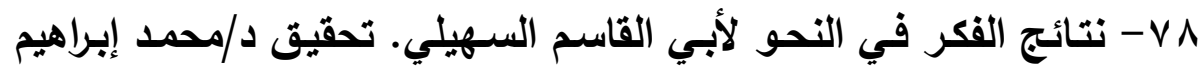

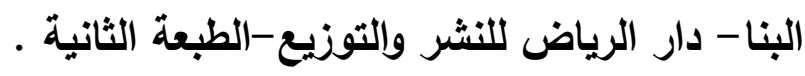

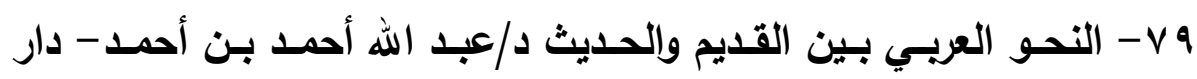

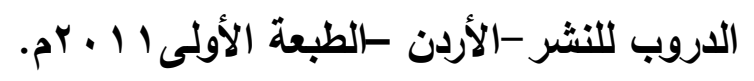
ـ - النحو الواضح في قواعد اللغة العربية.علي الجارم ومصطفى أمين.

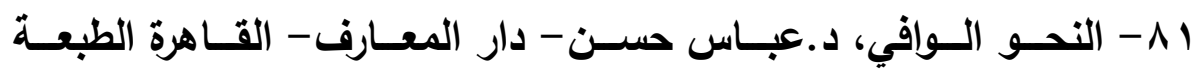

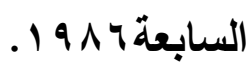

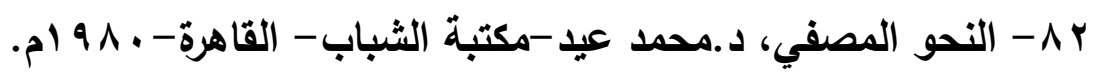

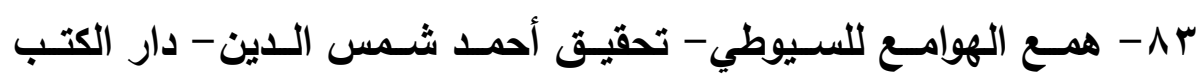

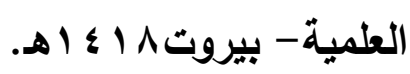
؟1 - الواضح في النحو، د.محمد خير الحلواني - منشورات مكتبة الثـاطئ

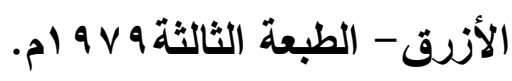

